\title{
Rivision of Pelagic Ostracods of the Subfamily Archiconchoecinae
}

\section{$\operatorname{AUTHOR}(\mathrm{S}):$}

Chavtur, V. G.; Stovbun, G. G.

\section{CITATION:}

Chavtur, V. G....[et al]. Rivision of Pelagic Ostracods of the Subfamily Archiconchoecinae. PUBLICATIONS OF THE SETO MARINE BIOLOGICAL LABORATORY 2003, 39(4-6): 139-219

\section{ISSUE DATE:}

2003-03-31

URL:

http://hdl.handle.net/2433/176312

RIGHT: 


\title{
Rivision of Pelagic Ostracods of the Subfamily Archiconchoecinae
}

\author{
V. G. Chavtur and G. G. StovbuN \\ Laboratory of Planktonology, Institute of Marine Biology, \\ Far East Branch, Russian Academy of Science, \\ Vladivostok 690041, Russia
}

\begin{abstract}
Pelagic ostracods of the subfamily Archiconchoecinae have been revised. Their single genus Archiconchoecia Müller, 1894 has been divided into seven genera and two subgenera: Archiconchoecia (Archiconchoecia) Müller, 1894, Archiconchoecia (Archiconchoecidia) subgen. nov., Archiconchoecilla gen. nov., Archiconchoecissa gen. nov., Archiconchoecemma gen. nov., Archiconchoecinna gen. nov., Archiconchoecetta gen. nov. and Archiconchoecerra gen. nov. Six new genera, a new subgenus and seven new species have been described in detail. A redescription was made for the additional known taxa, Archiconchoecilla maculata (Chavtur, 1977) and Archiconchoecemma orientalis (Chavtur, 1987). A detailed synonymy and data on distribution are given for all species, and for some species morphological comments also have been added. Keys were elaborated for all taxa. The distribution of ostracods of the subfamily Archiconchoecinae has been discussed.
\end{abstract}

Key words: Pelagic ostracods, Halocyprididae, Archiconchoecinae, Taxonomy

\section{Introduction}

Ostracods of the subfamily Archiconchoecinae are being studied for a little more than a century. The first species of this group was found in the surface waters of the Naples Bay, Mediterranean Sea, in late 19th century. Müller (1894) included it into a new genus Archiconchoecia and described as A. striata. In the early 20 th century he described two more species belonging to this genus, $A$. ventricosa $\left(0^{\circ}-2^{\circ} \mathrm{N}\right.$ and $3^{\circ} \mathrm{E}-6^{\circ} \mathrm{W}$, in a vertical tow from around $\left.3000 \mathrm{~m}\right)$ and $A$. cuneata $\left(19^{\circ} \mathrm{S}\right.$ and $20^{\circ} \mathrm{W}$, from $800-0 \mathrm{~m}$ ), from a deep-water zone in the Atlantic Ocean (Müller, 1906, 1908). In the same years, from the area of the British Isles, a new bathypelagic species, A. cucullata, was recorded by Brady (1902). The following communication on ostracods of this genus did not appear in the literature for 60 years, until Poulsen (1969) published a monograph, and gave this group of ostracods the rank of subfamily (Archiconchoecinae). Later, Deevey $(1978 \mathrm{c}$ ) described a part of specimens described as $A$. ventricosa (22-28 $\mathrm{S}$ and $166-177^{\circ} \mathrm{E}$, layer $\left.50-1500 \mathrm{~m}\right)$ as a new species $A$. poulseni.

In the period of $1970-80$ 's, active research were done in Archiconchoecinae. For example, Chavtur (1977a, 1987) described novel species (A. maculata and A. orientalis) for areas of the KurileKamchatka and Japan Trenches. Six new species (A. bimucronata, A. bifurcata, A. gastrodes, A. falcata, A. pilosa, A. longiseta) of this subfamily in various forms were found by Deevey (1978c) in deep-water samples from the Sargasso Sea at $32^{\circ} \mathrm{N}, 64^{\circ} \mathrm{W}(1000-2000 \mathrm{~m})$, and two from the Caribbean Sea, i.e. A. fabiformis $\left(11^{\circ} \mathrm{N}\right.$ and $66^{\circ} \mathrm{W}$, in a tow from $\left.1200-0 \mathrm{~m}\right)$ and $A$. bispicula $\left(17^{\circ} \mathrm{N}\right.$ and $85^{\circ} \mathrm{W}$, in a tow from ?2000-0 m). She also described another three species from the South Pacific (Deevey, 1978a) and the Pacific Sector of the Southern Ocean (Deevey, 1982):, i.e. A. versicula $\left(39^{\circ} \mathrm{S}, 107^{\circ} \mathrm{W}\right.$; between $1000-2000 \mathrm{~m})$, A. similis $\left(65^{\circ}-71^{\circ} \mathrm{S}, 160^{\circ}-180^{\circ} \mathrm{E}\right.$; between $\left.1015-1829 \mathrm{~m}\right)$ and $A$. bidens $\left(71^{\circ} \mathrm{S}\right.$, $179^{\circ} \mathrm{E}$; between $\left.1400-1600 \mathrm{~m}\right)$.

Recentry, Angel (1983) found A. sp. nov. 1 and A. sp. nov. 2 in the northeastern Atlantic at depths 1900-2100 and 2100-2300 m, respectively. Yet, the description and figures of these species were not given, and 20 species are thus known in this subfamily currently. 


\section{Material and Methods}

In this work, collections of Russian scientific expeditions to the North-West Pacific (R/V "Vityaz" in 1954, 1966, 1969; SRTM - 662 in 1959: SRTR "Orlyk" in 1969 and R/V "Cavalerovo" in 1980), North-East Pacific (R/V "Vityaz" in 1969), South-West Pacific (R/V "Vityaz" in 1957), North Atlantic (R/V "Lomonosov" in 1959) and Central Arctic (Drifting Station "North Pole - 2" in 1951) were used. Ten species of the subfamily Archiconchoecinae were found, of which seven were new to science. The collection data (coordinates and depth) of each species are given in the section "Systematics" of the description of species.

A detailed study of our collection of ostracods and critical analysis of the literature sources have revealed high morphological heterogeneity of this group and we assinged six genera, one subgenus, and 32 species (Table 1).

Main taxonomic characters used are as follows: shape and sculpturing of the shell; location of the asymmetrical glands on the valves; structure and shape of the frontal organ, and shape and sizes of the claspers on the 2nd antenna; shape of the teeth on the mandible basal endite; shape, structure and sizes of copulatory appendage; number of setae on the dorsal side of the 1st antenna, on the 2nd segment of the endopodite of the 2nd antenna (" $\mathrm{c}$ " - $\mathrm{e}$ " setae in male), and on the exopodite of the 6th limb; number of claws (claw-like setae) on the 3rd and 4th segments of the exopodite of the 6th limb and on the furca.

Followings were considered secondary important characters: sizes of the shell, limbs and its segments, setae and claws; armament of the setae; number of the setae on the epipodial appendages of the 5th and 6th limbs; correlation between length and height of the copulatory appendage.

The form of the teeth on the mandibular basal endite enabled us to divide the entire ostracod assembly into two main groups (they may correspond to a rank of tribe). In Group I these teeth were triangular, while in Group II they were serrated (saw-like). In the former, the right asymmetrical gland was at the topmost part of the posterior valve margin, whereas in the latter, in its middle (seldomly a little higher) or bottom part. Group I was very diverse, and can be divided into several subgroups. One (Archiconchoecissa gen. nov.) was definitely marked by a strong rostrum, developed posterodorsal spine (on right valve) and a distinct (as tile) sculpture and also by having two dorsal setae on the 1st antenna, setae "c"-"e" with very thick base on the 2nd antenna (in male), and 2-3 setae on the 2nd segment of the exopodite of the 6th limb. Part of the remaining species could be easily united into another subgroup (Archiconchoecia) by the form of the shell (valves were rounded with dorsomedial indentation) and by the presence of a very thick (in the middle part) clasper on the 2 nd antenna. The third subgroup (Archiconchoecilla gen. nov.) was isolated mainly on the basis of the following characters: the posterior margin of the shell was asymmetrical rounded (without spines) on the right and left valves; protopodite was longer than exopodite on the 2nd antenna; exopodite of the mandible was represented by one long seta, and its endopodite had usual dorsal seta. The rest species of Group I were mainly characterized by a short oval shell, the presence of 2-3 long setae on the mandibular exopodite and very short and fragile slender 2 nd (from the dorsal margin) seta on the 3rd segment of its endopodite (Archiconchoecemma gen. nov.).

Group II were also morphologically not uniform. The species of this group have both distinctly and slightly separated serrated (saw-like) teeth on the basal endite of the mandible. The first assembly of the group with distinctly separated teeth, i.e. Archiconchoecinna gen. nov. was additionally distinguished principally by the following characters: posterior margin about 1/3-1/4 of the way down was straight, the rest of margin was round and slopes downward to the anteroventral side; terminal segment of the 5th and 6th limbs beared a very short middle claw; dorsal margin on the 3rd segment of the exopodite of the 6th limb had a claw or a claw-like seta instead of usual seta.

For all established genera and subgenera, we prepared descriptions in a uniform pattern, and elaborated keys. The description of new species was given meticulous descriptions and illustrations. For the known species, the information on the synonymy and distribution was updated and for some 
Table 1. Systematic position of ostracods in subfamily Archiconchoecinae

\begin{tabular}{|c|c|}
\hline Literary data & Proposed system \\
\hline Archiconchoecia Müller, 1894 & Archiconchoecia (Archiconchoecia) Müller, 1894 \\
\hline \multirow{9}{*}{$\begin{array}{l}\text { 1. A. striata Müller, } 1894 \\
\text { - type-species }\end{array}$} & 1. A. (A.) striata Müller, 1894 - type-species \\
\hline & 2. A. (A.) aff. striata 1 (A. striata on George, 1979) \\
\hline & 3. A. (A.) aff. striata 2 (A. striata on Angel, 1981) \\
\hline & 4. A. (A.) instriata sp. nov. \\
\hline & 5. A. (A.) propinqua sp. nov. \\
\hline & Archiconchoecia (Archiconchoecidia) subgen. nov. \\
\hline & 6. A. (A.) apertesulcata sp. nov. \\
\hline & Archiconchoecissa gen. nov. \\
\hline & 7. A. pljusnini sp. nov. - type-species \\
\hline 2. A. aff. cuculata (on Angel, 1993) & 8. A. aff. pljusnini (A. aff. cucullata on Angel, 1993) \\
\hline \multirow[t]{4}{*}{ 3. A. cucullata (Brady, 1902) } & 9. A. cucullata (Brady,1902) \\
\hline & 10. A. aff. cucullata (A. cucullata on Angel, 1983) \\
\hline & $\begin{array}{l}\text { 11. A. aff. cucullata } 2 \text { (A. cucullata small form on Angel, } \\
\text { 1993) }\end{array}$ \\
\hline & Archiconchoecilla gen. nov. \\
\hline 4. A. maculata Chavtur, 1977 & 12. A. maculata (Chavtur, 1977) - type-species \\
\hline \multirow[t]{2}{*}{ 5. A. versicula Deevey, 1978} & 13. A. versicula (Deevey, 1978) \\
\hline & Archiconchoecemma gen. nov. \\
\hline 6. A. simula Deevey, 1982 & 14. A. simula (Deevey, 1982) \\
\hline \multirow[t]{3}{*}{ 7. A. orientalis Chavtur, 1987} & 15. A. orientalis (Chavtur, 1987) \\
\hline & Archiconchoecinna gen. nov. \\
\hline & 16. A. ecuneata sp. nov. - type-species \\
\hline \multirow[t]{5}{*}{ 8. A. cuneata (Müller, 1908) } & 17. A. arctica sp. nov. (A. cuneata on Chavtur, 1978) \\
\hline & 18. A. cuneata (Müller, 1908) \\
\hline & 19. A. aff. cuneata 1 (A. cuneata on Deevey, 1968) \\
\hline & 20. A. aff. cuneata 2 (A. cuneata on Deevey, 1978) \\
\hline & Archiconchoecetta gen. nov. \\
\hline 9. A. ventricosa Muller, 1906 & 21. A. ventricosa (Müller, 1906) type-species \\
\hline \multirow[t]{2}{*}{ 10. A. poulseni Deevey, 1978} & 22. A. poulseni (Deevey, 1978) \\
\hline & 23. A. inventricosa sp. nov. \\
\hline 11. A. bidens Deevey, 1982 & 24. A. bidens (Deevey, 1982) \\
\hline 12. A. fabiformis Deevey, 1978 & 25. A. fabiformis (Deevey, 1978) \\
\hline 13. A. bimucronata Deevey, 1978 & 26. A. bimucronata (Deevey, 1978) \\
\hline 14. A. bispicula Deevey, 1978 & 27. A. bispicula (Deevey, 1978) \\
\hline 15. A. bifurcata Deevey, 1978 & 28. A. bifurcata (Deevey, 1978) \\
\hline 16. A. gastrodes Deevey, 1978 & 29. A. gastrodes (Deevey, 1978) \\
\hline 17. A. falcata Deevey, 1978 & 30. A. falcata (Deevey,1978) \\
\hline \multirow[t]{2}{*}{ 18. A. pilosa Deevey, 1978} & 31. A. pilosa (Deevey, 1978) \\
\hline & Archiconchoecerra gen. nov. \\
\hline 19. A. longiseta Deevey, 1978 & 32. A. longiseta (Deevey, 1978) - type-species \\
\hline \multicolumn{2}{|l|}{ 20. Archiconchoecia sp. nov. 1} \\
\hline (on Angel, 1983$)^{*}$ & 33. Archiconchoecia sp. nov. 1 (on Angel, 1983)* \\
\hline \multicolumn{2}{|l|}{ 21. Archiconchoecia sp. nov. 2} \\
\hline (on Angel, 1983$)^{*}$ & 34. Archiconchoecia sp. nov. 2 (on Angel, 1983)* \\
\hline
\end{tabular}

*without description and figures

species comments on the morphology are given. Species previously described by the present author (Chavtur, 1977a, 1987), were redescribed on a unified pattern and its new illustrations were given. 
Keys were provided for all species of each genus and subgenus.

Among the species of another assembly with slightly separated teeth on the mandible, a special place was occupied by one species due to an unusual structure of the shell and some limbs (Archiconchoecerra gen. nov.), namely, there was well-defined lens-like structure near the posteroventral corner of each valve; one from 6 filaments placed on the distal segment of the 1st antenna was about twice as long as others; the 3 rd segment of the 6th limb did not have a dorsal seta: The rest species had a specific "ventricosa"-shape (anterior margin was extended beyond the rostrum), a low setting of the right asymmetrical gland (below the midheight of the posterior margin), and very thin claspers on the 2nd antenna in male (Archiconchoecetta gen. nov.).

All species, specified in Table 1 as "affinis", are actually undescribed. But since the literature does not specify the nomenclature of the specimens researched, we did not venture to isolate new taxa due to the lack of guarantees for their conservation.

The scientific text and illustrations to this work belong to V. G. Chavtur. G. G. Stovbun helped preparion of the manuscript. This work was supported by the Russian Foundation for Basic Research.

\section{Systematics}

\section{Order HALOCYPRIDA Dana, 1853 \\ Suborder HALOCYPRIDINA Dana, 1853 \\ Superfamily HALOCYPRIDOIDEA Dana, 1853 \\ Family HALOCYPRIDIDAE Dana, 1853 \\ Subfamily ARCHICONCHOECINAE Poulsen, 1969}

The subfamily Archiconchoecinae contains 7 genera, 2 subgenera and 34 species (Table 1).

Key to Subgenera and Genera of Subfamily Archiconchoecinae

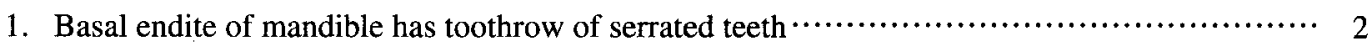

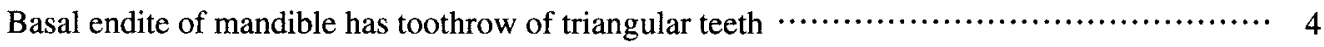

2. Right asymmetrical gland is located usual by less below $1 / 2$ (rare about $1 / 2$ ) shell

height on the posterior margin, basal endite of mandible is armed with slightly

separated teeth, exopodite of mandible is represented by usual seta

Right asymmetrical gland is located about or above $1 / 2$ the shell height on the posterior margin, basal endite of mandible is armed with distinctly separated teeth, exopodite of mandible is represented by very short spinous bristle

3. One filament on the 1 st antenna about twice as long as other 5, filaments on the endopodite of the 2nd antenna in female short and about $21 / 2$ - 3 shorter than its exopodite and protopodite …................................... Archiconchoecerra gen. nov. All filaments on the 1st antenna is about equal in length, filaments on the endopodite of the 2nd antenna in female are somewhat longer than its exopodite and protopodite

Archiconchoecetta gen. nov.

4. Rostrum is strong, prolonged, shell has posterodorsal spines, endopodite of the 2nd antenna in male bears " $\mathrm{c}$ " - " $\mathrm{e}$ " bristles with thick base ……..........Archiconchoecissa gen. nov. Rostrum is slight and not long, shell has no posterodorsal spines, endopodite of the 2nd antenna in male bears only " $c$ " and " $d$ " usual bristles …............................... 5

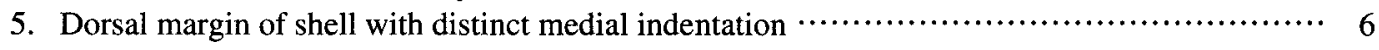

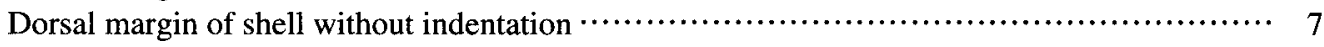

6. Shell less than $0,7 \mathrm{~mm}$, rostrum small, rostra incisure absent, cluspers on the 2nd antenna in male pointed at the tip 
Shell larger than $0,8 \mathrm{~mm}$, rostrum is developed, rostral incisure is present, claspers on the 2 nd antenna in male thickened at the tip

Archiconchoecia (Archiconchoecidia) nov. subgen.

7. Shell has asymmetrical posterior margins on the right and left valves, mandible

exopodite is represented by one seta …..............................Archiconchoecilla gen. nov.

Shell has symmetrical posterior margins on the right and left valves, mandible

exopodite is represented by $2-3$ setae …......................... Archiconchoecemma gen. nov.

\section{Genus Archiconcoecia Müller, 1894}

Archiconchoecia Müller, 1894: 225; 1906: $43-44$ (part); 1912: 55 (part); Deevey, 1968: 22 (part).

Type-species: Archiconcoecia striata Müller, 1894.

Composition

This genus contains two subgenera: Archiconcoecia (Archiconcoecia) Müller, 1894 and A. (Archiconcoecidia) subgen. nov. First subgenus includes 5 species and new subgenus consists of one species.

\section{Redescription}

Shell. Males are ranged in length from $0.60-0.85 \mathrm{~mm}$ and females from $0.57-0.85 \mathrm{~mm}$ (Angel, 1981 - both sexes from $0.5-0.6 \mathrm{~mm}$ ). Valves in male are rounded and slightly prolonged, and those in female are nearly rounded (in $A$. (A.) apertesulcata sp. nov. same as in male). Height of shell in male and female is $52-63 \%$ and $58-78 \%$ of the length respectively. Greatest height is at the posterior part. Rostrum is tiny or relatively developed, and rostral incisure is absent or barely noticeable. Dorsal margin is straight with distinct faint in $A$. (A.) propinqua medial indentation (except $A$. (A.) apertesulcata sp. nov.). Anterior and posterior margins are evenly rounded. Posterior margin without tubercles or with small knob-like tubercles (there asymmetrical glands in $A$. (A.) apertesulcata sp. nov.). Left and right asymmetrical glands are approximately at $70-80 \%$ and $60-70 \%$ of the way up the posterior margin respectively. Shell is with concentric striations (cross lines between concentric striations in A. (A.) propinqua sp. nov.). Rostrum is tiny or relatively developed.

Frontal organ. It is straight or slightly down-curved, short and narrow and extended barely beyond the down-curving distal segments of the 1st antenna. The organs in male and female are about $80-110 \%$ and $65-100 \%$ the length of the dorsal side of the 1st antenna respectively. Capitulum section is unseparated, rounded at the tip, and without hairs and spinules.

First antenna. The limb is 6-jointed, with one dorsal seta placed on the 2 nd segment. This seta is long, slim and armed with short hairs (or spinules). The 5th segment bears 2 , and the 6th -4 long filaments subequal in length, which are widened or not towards the tip and pointed or nearly pointed at the tip. Dorsal margin of the limb is $55-70 \%$ (120\% in A. (A.) aff. striata 1 according to George, 1979) of the filament length. Height of antenna (on the 2 nd segment) is about $20 \%$ of its length. The 4 tn segment is bare (without hairs).

Second antenna. The exopodite is thick or thin (in A. (A.) apertesulcata sp. nov.) and shorter than the protopodite (barely longer in $A$. (A.) apertesulcata sp. nov.). The total length of the 2nd - 9th segments of the exopodite is approximately $30-50 \%$ of the length of the 1st segment. Basal segment of the endopodite has warty surface (bare surface in A. (A.) apertesulcata sp. nov.), and distal segment is without long hairs and is armed with " $c$ " and " $d$ " bristles in male. Right clasping organ is very thick in the middle. Right and left claspers are tapering towards the tip (with terminal swollen in $A$. (A.) apertesulcata sp. nov.). The 5 filaments of the distal segment of the endopodite are distally barely tapering towards the tip or have an equal thickness throughout; they are subequal in length or 2 proximal filaments are some what longer than other 3. All filaments are shorter than protopodite 
(barely longer in male A. (A.) apertesulcata sp. nov.) and exopodite.

Mandible. The epipodite is without bristle. The exopodite is represented by one long or 2 relatively short setae. The 1st segment of the endopodite bears one dorsal and 4 ventral (one in female A. (A.) propinqua sp. nov.) setae; the 2 nd segment is with 3 dorsal (1-3 claw-like) and 2 ventral (one in female $A$. (A.) propinqua sp. nov.) setae. The 3rd segment bears 5 (in $A$. (A.) propinqua sp. nov.) or 7 setae, of which one (only in $A$. (A.) apertesulcata sp. nov.) or 3 dorsal are claw-like. The 1st dorsal seta is shorter than the 2 nd dorsal seta. The main terminal claw-seta of the mandible is longer than its endopodite (on the dorsal side) in female, and shorter, equal or longer in male. The basale is armed with 2 anterior setae and 2 lateral setae and one anterolateral seta near the articulation. Basal endite has toothrow with 6 distinctly separated triangular teeth (additional one large lateral tooth in $A$. (A.) aff. striata 1) and 2 short posterior bristles.

Maxilla. The basal segment of the endopodite bears 6 anterior and 3-4 posterior (one may be placed laterally) setae. The distal segment has 2 claw-like setae and 3 usual setae.

Fifth limb. The epipodial appendage has 3 groups of $4+4(3)+4(5)$ plumose setae ( 16 total). The 1st segment of the exopodite bears 5 (7 in A. (A.) apertesulcata sp. nov.) ventral and 1-3 (one in A. (A.) aff. striata 1 and 3 in $A$. (A.) apertesulcata sp. nov.) dorsal setae, and the 2 nd segment has 1-2 (one in $A$. (A.) striata) ventral and one dorsal setae. The middle claw-like seta on the distal segment is $50-65 \%$ the length of the exopodite (on the dorsal side) and subequal to the dorsal seta in length.

Sixth limb. The epipodial appendage is armed with 3 groups of $4(5)+4(5-6)+5(6)$ plumose setae (14-16 totally). The endopodite is with one long and one (or without it) short setae. The 1st segment of exopodite is without (only in A. (A.) striata) or with one dorsal and 2-3 (5 in A. (A.) apertesulcata sp. nov.) ventral setae; the 2 nd segment has only one ventral (plus one dorsal seta in female $A$. (A.) instriata sp. nov.) and the 3rd segment with one dorsal and one ventral setae. The 4th segment bears 2 setae and middle claw-like seta. Latter claw-like seta is $65-70 \%$ in male and $55-70 \%$ in female, and distodorsal seta (absent in A. (A.) striata) of the 1st segment is $20-50 \%$ length of the exopodite (on the dorsal side). The height of the exopodite is about $30-40 \%$ of the length.

Seventh limb. The limb is short, thick (50-60\% of the length) and $40-45 \%$ of its longest seta in length.

Copulatory appendage. The greatest height is nearly at the middle, and is $45-50 \%$ of the length from tip to dorsomedial indentation. It is tapering towards the base (untapering in A. (A.) striata) and the tip from the middle. The pointed tip is upturned (blunt protuberance in place of point in $A$. $(A$. appertesulcata sp. nov. ).

Caudal furca. This limb has 6 pairs of claws and a single unpaired bristle (it is absent in $A$. (A.) instriata sp. nov.).

Distribution. Members of this genus have been collected mainly in the tropical-subtropical surface water (rare lower $500 \mathrm{~m}$ ) of the World's Oceans in latitudinal range $36^{\circ} \mathrm{N}-42^{\circ} \mathrm{S}$ (subgen $A$. Archiconcoecia) and were caught in the Kurile-Kamchatka Trench $\left(44-48^{\circ} \mathrm{N}\right)$ from $2500-4000 \mathrm{~m}$ (subgen. Archiconchoecidia).

Key to Subgenera of Genus Achiconchoecia (Adult Male and Female)

1. Shell length is less than $0.7 \mathrm{~mm}$, it is prolonged in female and rounded in male; claspers of 2nd antenna have long base and are distally narrowed; exopodite of is mandible represented by 2 short setae (one long seta in $A$. (A.) aff. striata 1 )

A. (Archiconchoecia) Müller, 1894

Shell length over $0.7 \mathrm{~mm}$, it is prolonged in female and in male; claspers of $2 \mathrm{nd}$ antenna have short base and are terminal swollen; exopodite of mandible is represented by one long seta A. (Archiconchoecidia) subgen. nov. 


\section{Subgenus Archiconchoecia (Archiconchoecia) Müller, 1894}

\section{Composition}

This subgenus contains 5 species: A. (A.) striata Müller, 1894, A. (A.) instriata sp. nov., A. (A.) propinqua sp. nov., A. (A.) aff. striata 1 (A. striata sensu George, 1979) and A. (A.) aff. striata 2 (A. striata sensu Angel, 1981).

\section{Description}

Shell. Valves in male are prolonged and in of female rounded. Rostrum is tiny. Rostral incisure is absent (obscure in A. (A.) aff. striata 2). Posterior margin is without tubercles.

Second antenna. The exopodite is thick and shorter than the protopodite. Basal segment of the endopodite has warty surface. The right is clasper with prolonged base and distally narrowed. The left clasper is curved and about as long as the right one. The 5 filaments on the distal segment of the endopodite are shorter than the protopodite.

Mandible. The exopodite is represented by 2 somewhat short setae (one long seta in $A$. (A.) aff. striata 1). All dorsal setae on the 2 nd segment and 2 dorsal setae on the 3rd segment are claw-like.

Fifth limb. The 1st segment of the exopodite bears 5 ventral and 1-2 dorsal setae.

Sixth limb. The 1st segment of the exopodite has 2-3 ventral setae.

Copulatory appendage. Pointed tip upturned.

\section{Key to Species of Subgenus Archiconchoecia (Archiconchoecia)}

(Adult Female and Male)

1. Exopodite of mandible is represented by 2 short setae

Exopodite of mandible is represented by 1 long seta

A. ( A.) aff. striata 1

2. Each valve has one lens-like structure near ventral margin; dorsal side of the 3rd segment on exopodite of mandible is straight...

Valves lack lens-like structure; dorsal side of the 3rd segment on exopodite of mandible with distal protuberance

A. (A.) propinqua sp.nov.

3. Rostrum narrow and prolonged; endopodite of 2 nd antenna has short " $a$ " and " $b$ "

bristles

A. (A.) aff. striata 2

Rostrum is wide and not prolonged; endopodite of 2 nd antenna has long " $a$ " and " $b$ "

bristles

4. Mediovental lens-like structure on each valve is small; middle part of right clasper of 2 nd antenna is about twice as wide as the base; distodorsal seta of 1 st segment of 5 th limb is about $60 \%$ length of this limb (on the dorsal side); endopodite of 6th limb has one long and one short setae and 1 st segment of exopodite is without dorsal seta

Medioventral lens-like structure one each valve is large; middle part of right clasper on 2nd antenna is about 2.5-3 times as breadth as the base; distodorsal seta of 1st segment of 5 th limb is barely over $100 \%$ the length of this limb; endopodite of 6th limb has only one long seta and 1st segment of exopodite is with dorsal seta

A. (A.) instriata sp. nov.

\section{Archiconchoecia (Archiconchoecia) instriata Chavtur sp. nov.}

(Figs. 1-3 and 11, A)

? Archiconchoecia striata: Juday, 1906: 16, pl. 3, figs. 1-3; Tseng, 1970: 285, 286, 289, 295, table 1, figs. 5,10; Deevey, 1978a: 44, 46, table 1; 1983: table 1; Martens, 1979: 309-311, Abb. 4a-g; 1981: 68, 88, 89, 90; Hanai et al., 1980: 51; Chen et al.; 1983: 91, fig. 9; Yin, 1991: 78; Chen and Lin, 1994a: 446, 447, 449; 1995: 41-42, fig. 47. 
Material examined

Holotype N1100 - adult male, length $0.60 \mathrm{~mm}$ and height $0.34 \mathrm{~mm}$, appendages are mounted on slide and valves remained in alcohol. In collection of the Museum of Institute of Marine Biology, Vladivostok, Russia (together with paratypes). Type-Locality - SRTR “Orlik” , 36 $10^{\prime} \mathrm{N}, 142^{\circ} 21^{\prime} \mathrm{E}$, depth 100-0 m, 3 June 1967.

Paratypes. N1101 - adult male, length $0.62 \mathrm{~mm}$, height $0.35 \mathrm{~mm}$ from same sample as of holotype; N1 102 - adult female, length $0.58 \mathrm{~mm}$, height $0.36 \mathrm{~mm}$, SRTR “Orlik” , $21^{\circ} 54^{\prime} \mathrm{N}$, $138^{\circ} 18^{\prime} \mathrm{E}$, depth 100-0 m, 21 May 1967; N1 103 - adult female, length $0.57 \mathrm{~mm}$, height $0.35 \mathrm{~mm}$, SRTR “Orlik" , approximately $33^{\circ} \mathrm{N}, 138^{\circ} \mathrm{E}$, depth $100-0 \mathrm{~m}$, date in 1967 , appendages of paratypes on slides and valves in alcohol.

Additional Specimens - Adult male, length $0.60 \mathrm{~mm}$, SRTR “Orlik" , 21 ${ }^{\circ} 54^{\prime} \mathrm{N}, 38^{\circ} 18^{\prime} \mathrm{E}$, depth 100-0 m, 21 May 1967; adult female, length $0.62 \mathrm{~mm}, \mathrm{R} / \mathrm{V}$ "Cavalerovo" station $43,33^{\circ} 15^{\prime} \mathrm{N}$, $148^{\circ} 27.5^{\prime}$ E, depth $100-0 \mathrm{~m}, 28$ August 1980 ; juvenile, length $0.5 \mathrm{~mm}$, “SRT - 662”, station 21 , $35^{\circ} 14^{\prime} \mathrm{N}, 152^{\circ} 07^{\prime} \mathrm{E}$, depth $200-0 \mathrm{~m}, 16$ September 1959; adult female and juvenile (in poor condition), $\mathrm{R} / \mathrm{V}$ "Vityaz" , station $3210,34^{\circ} 02^{\prime} \mathrm{N}, 146^{\circ} 30^{\prime} \mathrm{E}$, depth $230-108 \mathrm{~m}, 23$ October 1954; adult female (in poor condition), R/V “Vityaz” , station 3212, 35 ${ }^{\circ} 46^{\prime} \mathrm{N}, 145^{\circ} 42^{\prime} \mathrm{E}$, depth 600-0 m, 24 October 1954.

All materials including holotype and paratypes were collected by Juday's Plankton Net ( $S=0.1$ $\left.\mathrm{m}^{2}\right)$.

Etymology

The specific name "instriata", from Latin "in" [=not] and "striata" [=lined], refers to closeness, but not identity to species $A$. (A.) striata Müller, 1894.

Description of adult male

Shell (Fig. 1, A-D). The length is $0.60-0.62 \mathrm{~mm}$ (from 0.62 to $0.68 \mathrm{~mm}$ according to Chen et al., 1983 and Martens, 1979). Valves are slightly prolonged. Height of shell is $56 \%$ of the length (from 56 to $59 \%$ according to Martens, 1979 and Chen et al., 1983). Greatest height is at the posterior part. Rostrum is tiny. Rostral incisure absent. Dorsal margin has slight and small medial indentation. Numerous small glands placed are along anterior, ventral and posterior margins. Posterior margin is evenly rounded. Each valve has one medial large clear lens-like structure near ventral margin. Left and right asymmetrical glands are located approximately at 70 and $60 \%$ of the way up the posterior margin respectively. The surface of the shell is sculptured with concentric striae.

Frontal organ (Fig. 1, A-G). It is straight, extended slightly beyond the down-curving distal segments of the 1st antenna, in nearly equal thickness, and is approximately $80 \%$ of the length of the 1st antenna (on the dorsal side). The stem is of equal thickness throughout. The capitulum section is unseparated, rounded at the tip, and without hairs or spinules.

First antenna (Fig. 1, E-H). The limb is 6-jointed. Dorsal seta of the 2nd segment is long, slim and armed with short coarse hairs. Long filaments on the 5 th and 6 th segments are distally unwidened, slightly pointed at the tip and subequal in length. Dorsal margin of the limb is $65-70 \%$ of the filament length. Height of antenna (on the 2 nd segment) is $18-21 \%$ of the length. The 1 st segment is wide, about $75 \%$ or equal in length with the 2 nd segment, and has a few internal dark brown pigment spots.

Second antenna (Fig. 1, I-M). The exopodite is thick (thicker at the proximal part) and shorter than the protopodite (about $70 \%$ of its length). The total length of the 2 nd- 9 th segments of the exopodite is about $40 \%$ of the 1 st segment in length. Basal segment of the endopodite has warty surface are long bristles " $a$ " and " $b$ ". The bristles " $c$ " and "d" placed on its 2nd segment are thin and of usual type. The right clasper is very thick of the middle (about 2.5-3 times as wide as its base), with base prolonged and tapering towards the tip. The left clasper is developed, curved, without terminal thickening and about same as long as the right one, but considerably thinner than it. The 5 filaments on the endopodite are subequal in length and have an equal thickness throughout, rounded or barely pointed at the tip and are about half and two-thirds the length of the protopodite and exopodite 
respectively.

Mandible (Figs. 2, A, B and 11, A). The epipodite is well developed and without bristle. The exopodite is represented by 2 relatively short setae. The 1 st segment of the endopodite is with tuberous dorsal margin and bears one dorsal and 4 ventral ( 2 long and 2 medium length) setae, the 2nd segment bears 3 stout (claw-like) dorsal and 2 usual long ventral setae. The distal segment has straight dorsal margin and 7 setae ( 3 dorsal are claw-like), longest seta of which is about as long as the endopodite (on the dorsal side), and the 1st dorsal seta shorter than the 2nd seta. Basale is armed with 2 anterior and 2 lateral setae and one anterolateral seta and the anterior row of the hairs near the articulation. Basal endite has toothrow with distinctly separated triangular teeth and 2 short posterior bristles. Coxal endite is armed with 3 closely set toothrows. Numerous thin ventral spines are placed on the flat masticatory pad.

Maxilla. The basal segment of the endopodite bears 6 (5-6 plumose) anterior and 3 (one plumose) posterior setae. The distal segment is armed with 2 claw-setae and 3 usual setae.

Fifth limb (Fig. 2, C, D). The epipodite is torn. The 1st segment of the exopodite bears 5 (one plumose) ventral and 2 (one plumose) dorsal setae, one of the latter is about as long as the dorsal margin of the exopodite. The 2 nd segment is with 2 ventral and one dorsal setae, and the latter seta is about $75 \%$ length of the exopodite (on the dorsal side). Dorsal side of the 1st segment and the ventral one of the 2 nd segment are hairy. The dorsal claw-seta is borne on the distal segment is subequal to the middle claw-seta in length.

Sixth limb (Fig. 2, E, F). The epipodial appendage has 3 groups of $5+5(6)+5(6)$ plumose setae. The endopodite bears one long plumose seta. The 1st segment of the exopodite is with one dorsal and 2 ventral plumose setae. The 2 nd segment bears one ventral and 3 rd segment is with one long dorsal and one short ventral setae. Two usual setae and one middle claw-seta are placed on the 4th segment. Latter claw-seta is $65 \%$ and dorsal seta of the 1 st segment is about $50 \%$ the length of the exopodite (on the dorsal side).

Seventh limb. This is deformed.

Copulatory appendage. (Figs. 2, G, H and 3, A). It is in poor condition. Penis is distally and proximally narrowed and tapers towards the base and tip from its middle. The height is greatest at the middle. The pointed tip upturned. Penis is with 2 or without (unnoted) muscles.

Caudal furca (Figs. 2, G, H and 3, H). This limb has 6 slim and long paired claws. Unpaired bristle is probably absent.

Description of adult female

Shell (Fig. 3, B-D). The length is $0.57-0.58 \mathrm{~mm}(0.58 \mathrm{~mm}$ according to Chen and Lin, 1995 and $0.62-0.63 \mathrm{~mm}$ in Martens, 1979). Height of shell is $60-62 \%$ of the length (65\% according to Chen and Lin, 1995 and $70 \%$ in Martens, 1979). Medioventral lens-like structures are less than in male.

Frontal organ (Fig. 3, E). It is about $70 \%$ of the 1 st antenna in length (on the dorsal side).

First antenna (Fig. 3, E). Dorsal margin of the limb is $65 \%$ the length of the filaments. Height (of the 2 nd segment) is $21 \%$ of the length. The 1 st segment is as long as the 2 nd segment and thinner than in male.

Second antenna (Fig. 3, F). The exopodite is thicker at the proximal part and is about $90 \%$ of the its length. The 2 nd segment of the endopodite lacks "c"-"e" bristles. The 5 terminal filaments are subequal in length, barely pointed at tip, and ere of equal thickness throughout.

Mandible (Fig. 3, G). Main terminal claw-seta is longer than the endopodite (on the dorsal side).

Fifth limb (Fig. 3, H). The endopodite bears one midlong plumose seta. The 2nd segment of the exopodite has one dorsal and one ventral setae.

Sixth and seventh limbs. They are torn.

Caudal furca. As in male. 


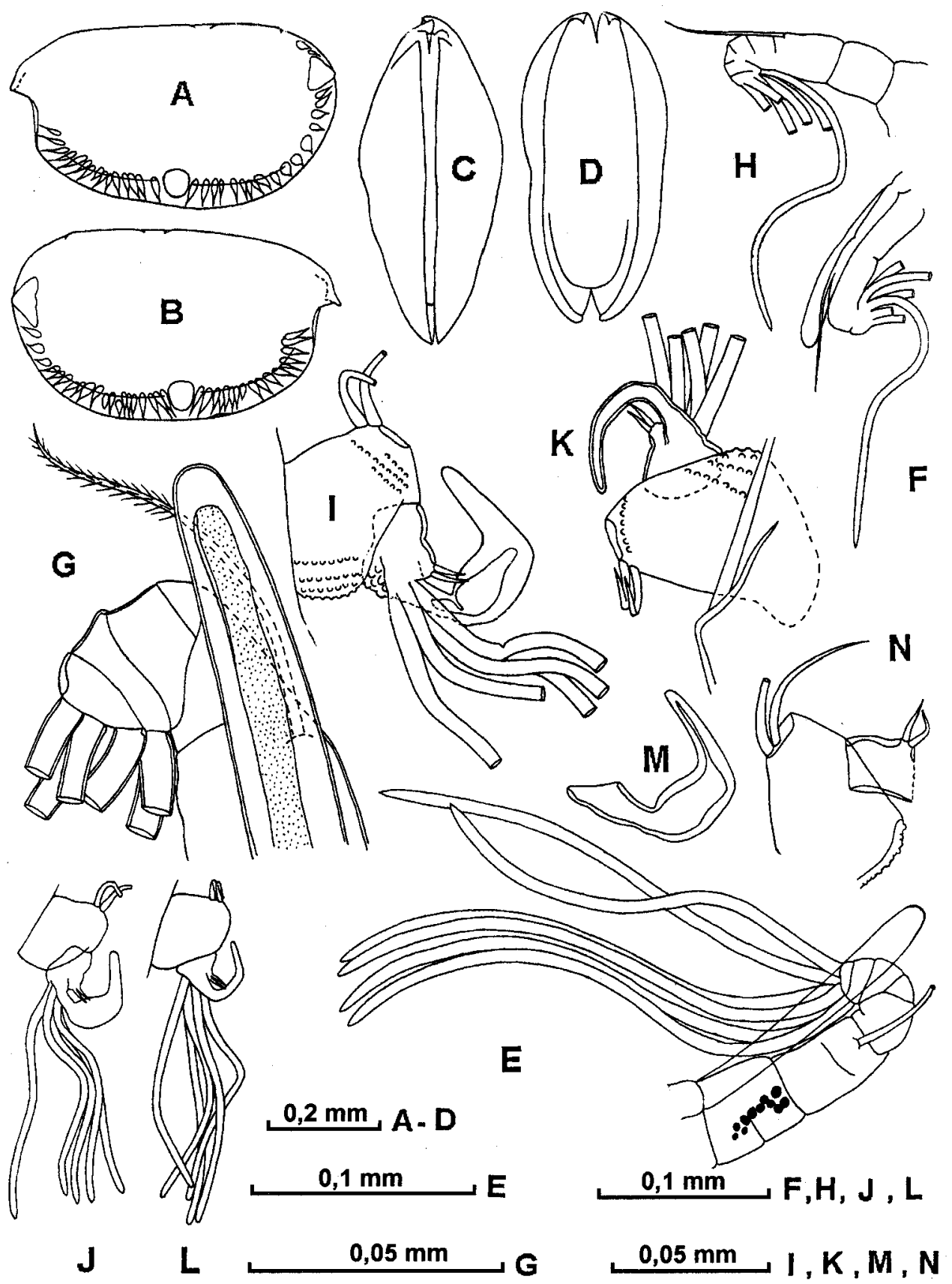

Fig. 1. Archiconchoecia (Archiconchoecia) instriata sp. nov. (male: 1101 - A-C, E, I-L; 1100 - D, F-H, $\mathrm{M}, \mathrm{N}$ ). A and B - lateral view of left and right valves of shell, $\mathrm{C}$ and $\mathrm{D}$ - ventral view of shell, $\mathrm{E}$ and $\mathrm{F}$ - frontal organ and 1st antenna, G - distal part of frontal organ and 1st antenna, H - 1st antenna, I and $\mathbf{J}$ - right endopodite of 2 nd antenna, $\mathrm{K}$ and $\mathrm{L}$ - left endopodite of 2 nd antenna, $1 \mathrm{M}$ right clasper of 2nd antenna, $\mathrm{N}$ - fragment of endopodite of the 2 nd antenna. 


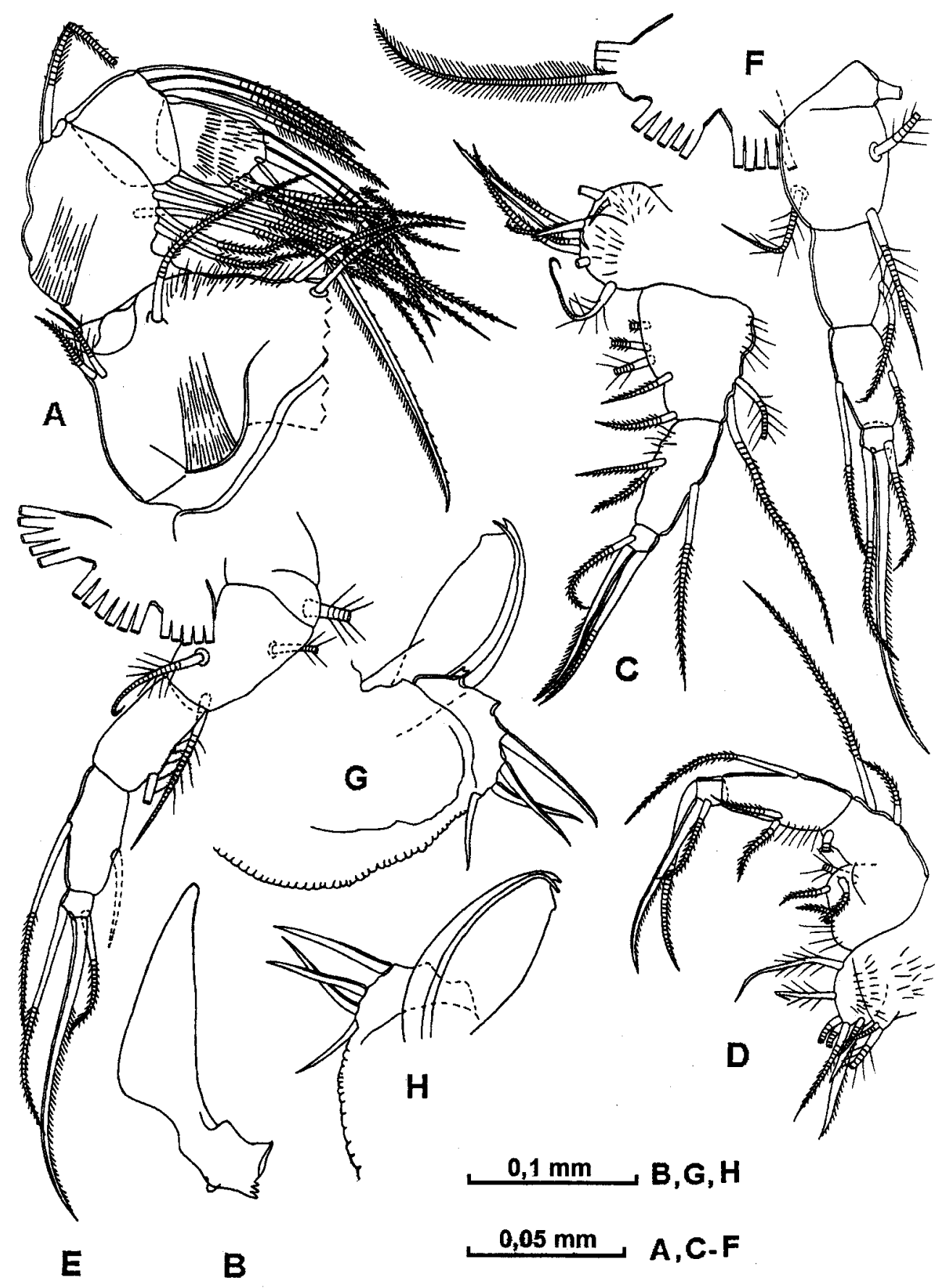

Fig. 2. Archiconchoecia (Archiconchoecia) instriata sp. nov. (male: 1100). A - mandible, B - coxal segment of mandible, C and D - fifth limb, E and F - sixth limb, G and H - furca and penis. 

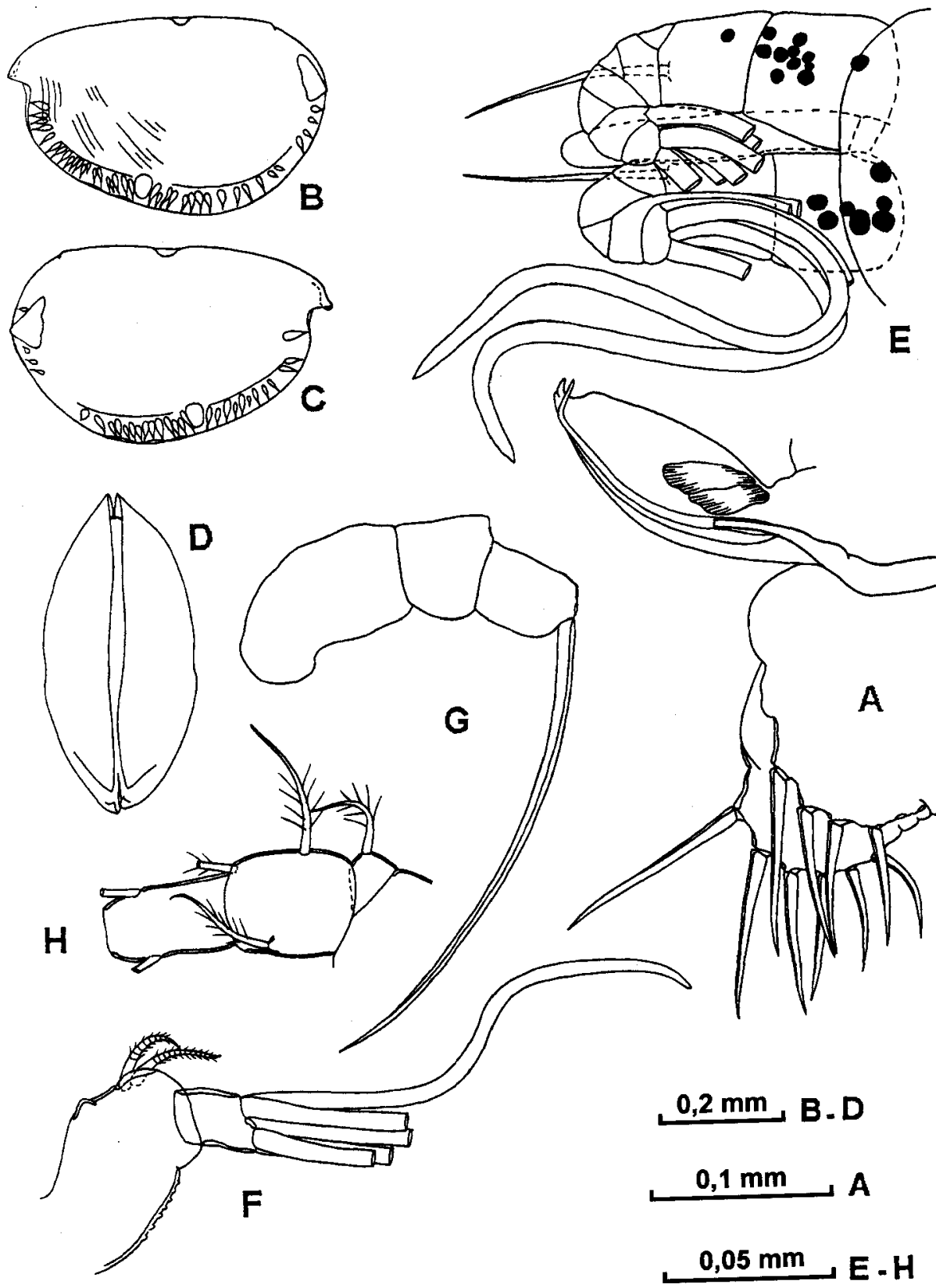

Fig. 3. Archiconchoecia (Archiconchoecia) instriata sp. nov. (male: 1101 - A, female: 1102 - B, female: 1103 - F-H) A - furca and penis, B and C - lateral view of left and right valves of shell, D - ventral view of shell, $\mathrm{E}$ - frontal organ and 1st antenna, F - endopodite of 2nd antenna, G - endopodite of mandible, $\mathrm{H}$ - proximal part of sixth limb. 
Distribution.

This species was caught in the north-western Pacific $\left(21-35^{\circ} \mathrm{N}\right.$ and $\left.138-152^{\circ} \mathrm{E}\right)$ from $0-200 \mathrm{~m}$ (and one sample: in a vertical tow from 600-0 m). Apparently this species occurs in vicinity of SanDiego (Juday, 1906), south-eastern Pacific (30-36 ${ }^{\circ}$ S) between 0-500 m (Deevey, 1978c, 1983; Martens, 1979) South-China Sea and tropical surface and deep water of the north-western Pacific (Chen et al., 1983; Chen and Lin, 1994a; 1995; Yin, 1991).

\section{Comparison}

This species is most close to A. (A.) striata and A. (A.) propinqua sp. nov. But it differs from the first species by larger medial lens-like structure on the valves (near of the middle its ventral margin), by longer distodorsal seta on the 1 st segment and dorsal seta on the 2 nd segment and middle claw-seta on the 3rd segment of the exopodite of the 5th limb, by presence of only one long seta on the endopodite of the 6th limb, by distally narrowed penis, by absence on the caudal furca of unpaired bristle. From the second species it differs in the following: asymmetrical glands are located lower on the posterior margin of valves; shell has concentric striae and middle lens-like structure on the surface; frontal organ is smaller and rounded at the tip; dorsal margin on the 3rd segment of the mandible endopodite is without distal ledge; on the 1 st and 2 nd segments are greater number of ventral setae in female, and main (middle) claw-seta on the 3rd segment of the mandible endopodite are larger; on the 1st segment of the maxilla are smaller number of setae; distodorsal seta and main middle claw-seta on the $1 \mathrm{st}$ and the 3 rd segments of the 5 th limb; are longer respectively distodorsal seta on the 1st segment of the exopodite of the 6th limb is longer; furca is without unpaired bristle.

\section{Archiconchoecia (Archiconchoecia) propinqua Chavtur sp. nov.}

(Figs. 4-6 and 11, B, C)

Material examined

Holotype. N1 104 - adult male, length $0.64 \mathrm{~mm}$ and height $0.40 \mathrm{~mm}$, appendages are mounted on slide and valves remained in alcohol. In collection of the Museum of Institute of Marine Biology, Vladivostok, Russia (together with paratype). Type-Locality - R/V “Cavalerovo", station 74, $33^{\circ} 02 \mathrm{~N}$ and $139^{\circ} 01 \mathrm{E}$, depth $100-0 \mathrm{~m}, 5$ September 1980 (Plankton Juday's Net, $\mathrm{S}=0.1 \mathrm{~m}^{2}$ ).

Paratype. '1105 - adult female, length 0.65 and height $0.45 \mathrm{~mm}$ (appendages are mounted on slide and valves in alcohol). R/V "Cavalerovo", station 58, 34 $29 \mathrm{~N}$ and $140^{\circ} 45 \mathrm{E}$, depth $100-0 \mathrm{~m}, 1$ September 1980 (Plankton Juday's Net, $S=0.1 \mathrm{~m}^{2}$ ).

\section{Etymology}

The species name "propinqua", from Latin [=closely related], refers to morphological relationship of $A$. (A.) striata Müller, 1894.

\section{Description of adult male}

Shell (Fig. 4, A-C). The is length $0.64 \mathrm{~mm}$. Valves are slightly prolonged. The greatest height is at the posterior part and is about $60 \%$ of the length. Rostrum is tiny. Rostral incisure is absent. Dorsal margin has faint indication of medial indentation. Numerous small glands are placed along anterior, ventral and posterior margins. Upper half of rounded posterior margin is more convex than lower part. Medial lens-like structures are absent near ventral margin. Left and right asymmetrical glands are approximately 80 and $70 \%$ of the way up the posterior margin respectively. Surface of the shell is sculptured concentric striae and cross lines between them.

Frontal organ (Fig. 4, D). It is straight, extended slightly beyond the down-curving distal segments of the 1 st antenna, and is about $110 \%$ the length of the dorsal side of the 1 st antenna. The stem is of equal thickness throughout. Capitulum section is slightly separated, pointed at the tip, and without hairs and spinules. 
First antenna (Fig. 4, D). The limb is 6-jointed. Second segment has long, slim dorsal seta, which is armed with short hairs. The 5th and 6th segments bear 6 long filaments equal in length, distally unwidened and pointed at the tip. Dorsal margin of the limb is $58 \%$ the length of the filaments. Height of antenna (on the 2nd segment) is $22 \%$ of the length. The 1 st segment is slightly longer and higher than the 2nd segment, and has no dark pigment spots.

Second antenna (Fig. 4, E-G). The exopodite is thick (thicker at the middle) and shorter than the protopodite (about $80 \%$ of its length). The total length of the 2nd-9th segments of the exopodite is about $40 \%$ the length of the 1st segment. Basal segment of the endopodite has warty surface, are long bristles " $a$ " and " $b$ ". Bristles " $c$ " and " $d$ ", placed on its segment are somewhat thick proximally. The right clasper is about twice as thick as its base, and tapering towards the tip; its base is prolonged. The left clasper is developed and in curved, and without terminal thickening and is about as long as the right one. The filament " $\mathrm{g}$ " on the 2 nd segment is longer and thicker than the other 4 . These filaments are slightly tapering towards the tip, rounded at the tip and are about two-thirds the length of the protopodite and exopodite.

Mandible (Figs. 5, A and 11, B, C). The epipodite is well developed and without bristle. The exopodite is represented by 2 relatively short setae. The 1 st segment of the endopodite has tuberous dorsal margin, and bears one dorsal and 4 ventral ( 2 long and 2 midlong) setae. The 2 nd segment is with 3 stout (claw-like) dorsal and 2 usual long ventral setae. The 3 rd segment has noticeable distal ledge on the dorsal margin and bears 5 setae, 3 dorsal of which are claw-like and 2 ventral setae are usual type. Basale is armed with 2 anterior and 2 lateral setae, one anterolateral seta, and the anterior row of the hairs near the articulation. Basal endite has toothrow with 6 distinctly separated triangular teeth and 2 short posterior bristles. Coxal endite is armed with 3 closely set toothrows. Numerous thin ventral spines are located on the flat masticatory pad.

Maxilla (Fig. 5, B). The basal segment of the endopodite has 6 anterior (all plumose), 3 (one plumose) posterior and one medial setae. The distal segment is armed with 2 claw-setae and 3 usual setae.

Fifth limb (Figs. 5, C and 6, H). The epipodial appendage has 3 groups of $4+3+5$ plumose setae. The 1st segment of the exopodite bears 5 (one plumose) ventral and 2 (one plumose) dorsal setae, of which distodorsal seta is about $90 \%$ the length of the exopodite (on the dorsal side). The 2 nd segment is with 2 ventral and one dorsal setae. Latter seta is about $75 \%$ and main (middle) terminal claw-like seta is $50 \%$ the length of the exopodite. The dorsal and middle terminal claw-setae are subequal in length. The ventral side of the 2 nd segment is covered with hairs.

Sixth limb (Fig. 5, D). The epipodial appendage bears 3 groups of $4+5+6$ plumose setae. Only one long plumose seta is placed on the endopodite. The 1st segment of the exopodite is with one dorsal and 2 ventral plumose setae. The 2 nd segment bears one ventral and 3 rd segment one long dorsal and one short ventral setae. The terminal segment is armed with two usual setae and middle one claw-seta. These claw-seta and dorsal seta are about $70 \%$ and $30 \%$ the length of the exopodite (on the dorsal side).

Seventh limb. This limb is torn.

Caudal furca (Fig. 4, H). This limb has 6 pairs of slim and long claws, and single unpaired bristle.

Copulatory appendage (Fig. 4, H). It is tapering towards the base and the tip from the middle. The greatest height is at the middle. The pointed tip is upturned. No muscles are noted on the penis.

Descripthion of adult female

Shell (Fig. 6, A-C). The length is $0.65 \mathrm{~mm}$. Shell is rounded and with strongly convex ventral margin. The height is about $70 \%$ of the length.

Frontal organ. It is in poor condition.

First antenna. As in male.

Second antenna (Fig. 6, D, E). The 1st segment of the exopodite is twice the total length of 2 nd- 

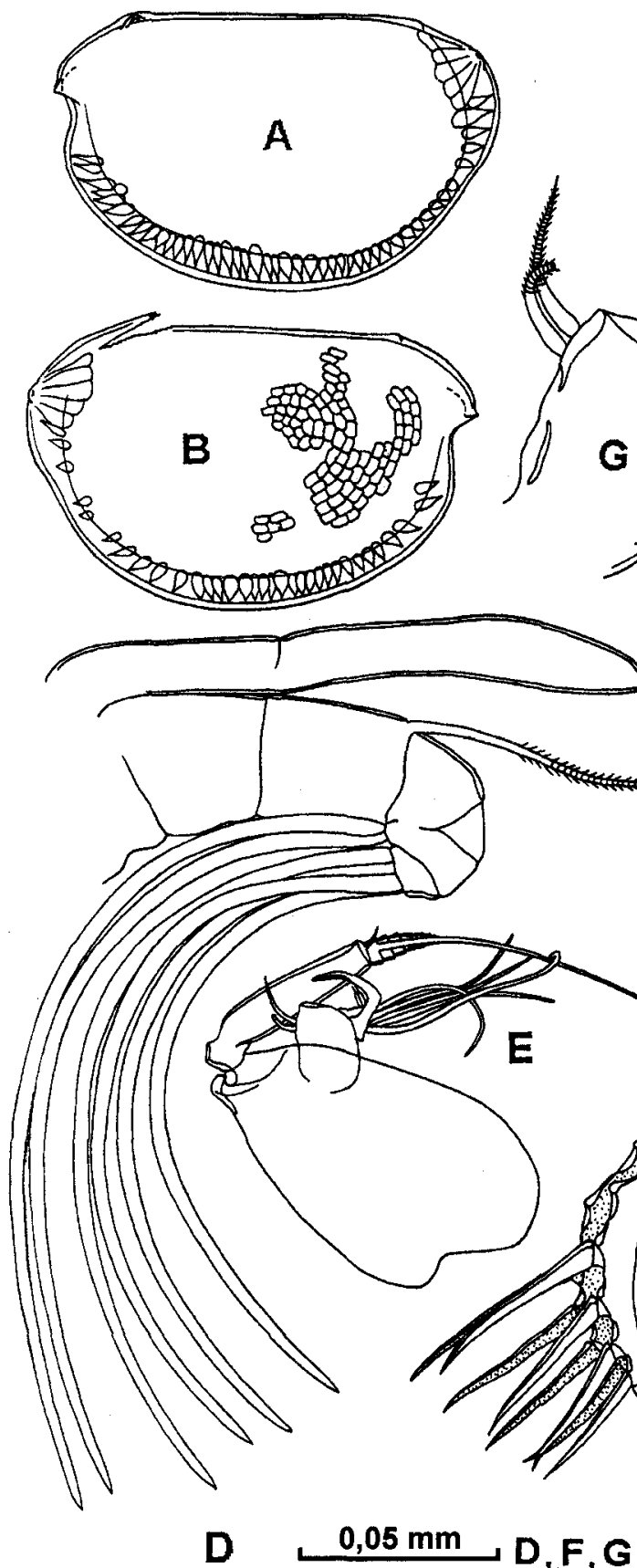

F
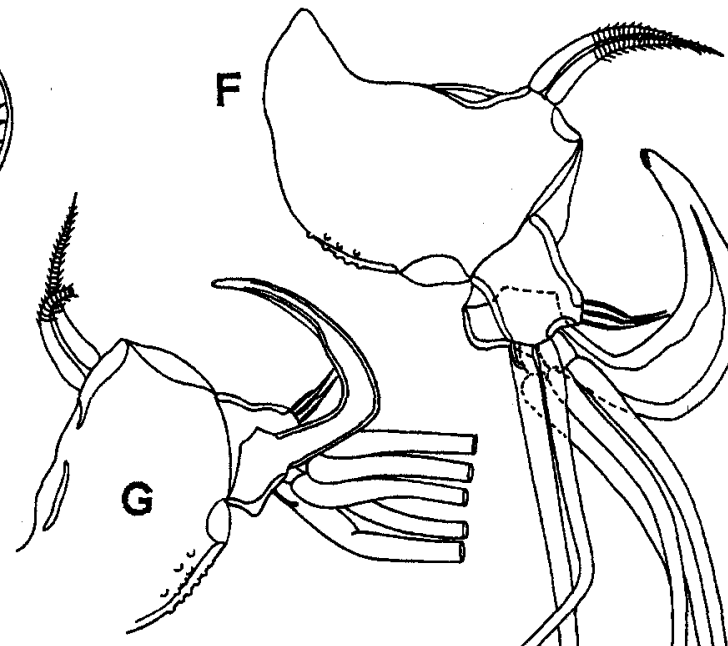


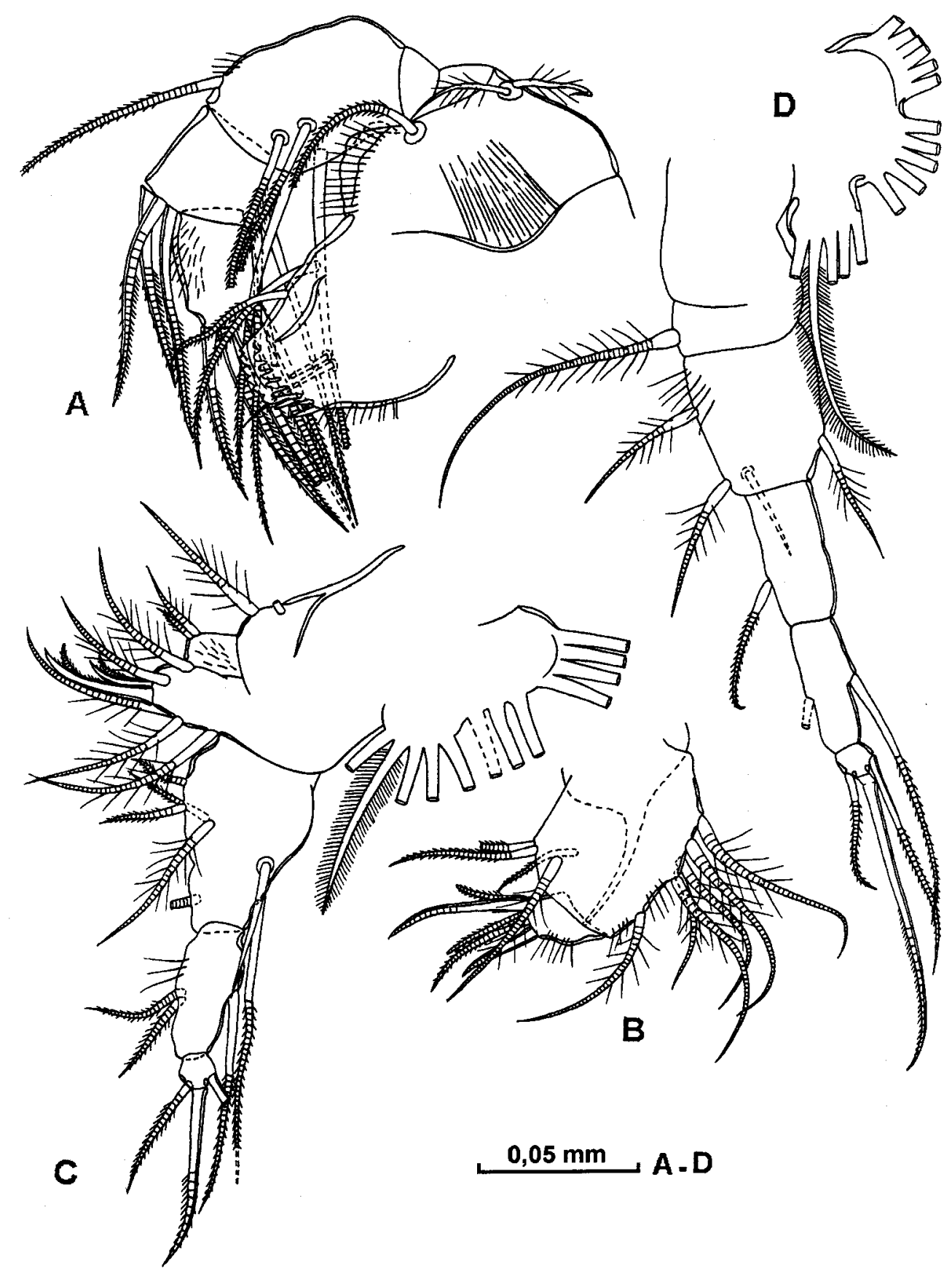

Fig. 5 Archiconchoecia (Archiconchoecia) propinqua sp. nov. (male: 1104) A - mandible, B - maxilla, C - fifth limb, D - sixth limb. 

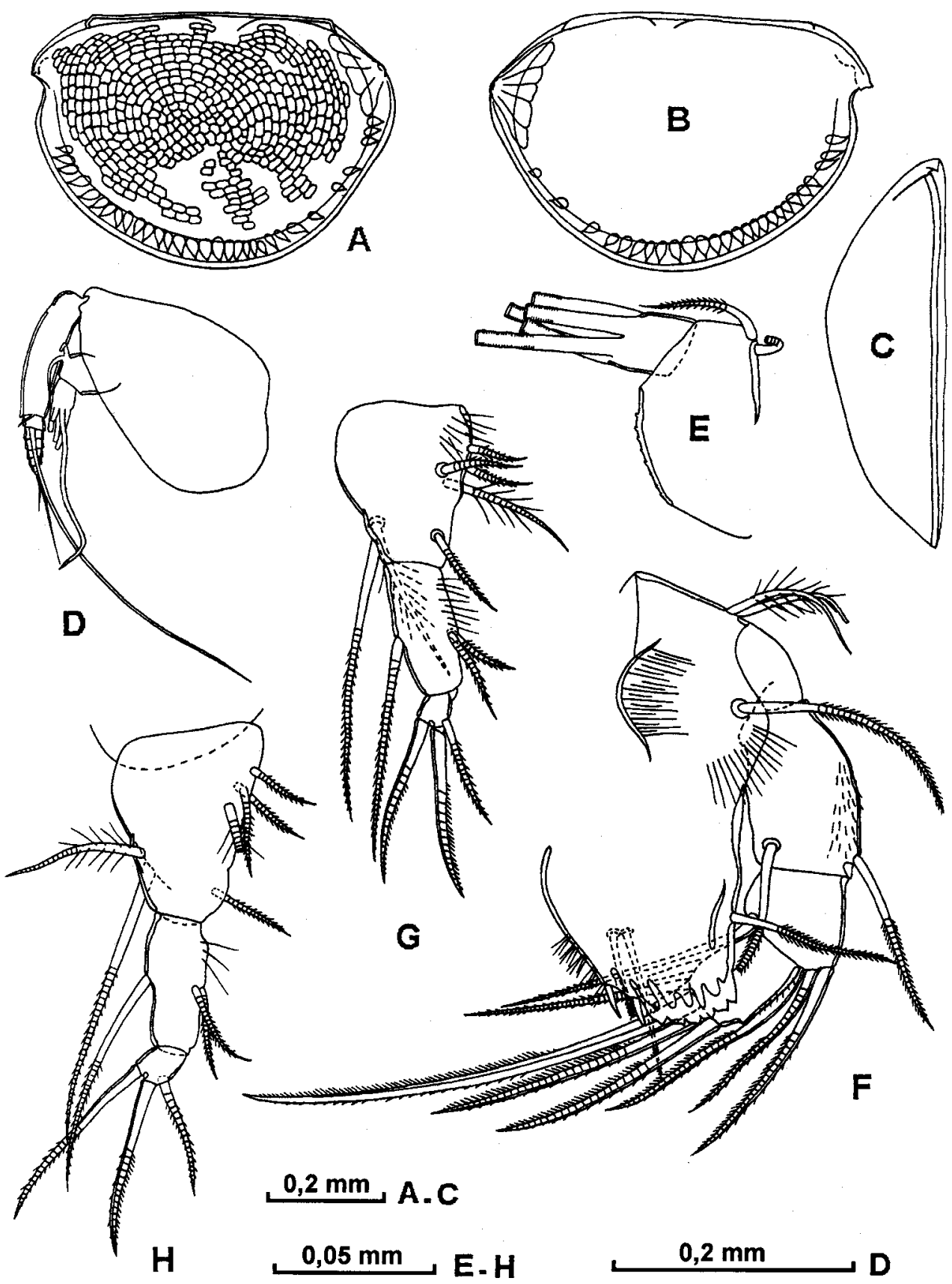

Fig. 6 Archiconchoecia (Archiconchoecia) propinqua sp. nov. (female: 1105 - A-G, male: 1104 - H) A and $B$ - lateral view of left and right valves of shell, C - ventral view of right valve, D - 2nd antenna, $\mathrm{E}$ - endopodite of 2nd antenna, F - mandible, $\mathrm{G}$ and $\mathrm{H}$ - distal part of fifth limb. 
9th segments. Endopodite without "a"-"e" bristles. Terminal " $\mathrm{g}$ " filament is slightly tapering towards the tip or has an equal thickness throughout, pointed at the tip and is about $3 / 4$ the length of the protopodite and exopodite (" $h$ "-" $\mathrm{f}$ " filaments are broken).

Mandible (Fig. 6, F). The 1st segment of the endopodite bears one dorsal and one ventral and 2nd segment has 3 dorsal and one ventral setae. Main terminal claw-seta is shorter than the endopodite (on the dorsal side).

Maxilla and fifth limb (Fig. 6, G, H). They are as in male.

Seventh limb. It is torn. The setation of the distal segment and the length of its main claw-seta are as in male.

Caudal furca. As in male.

\section{Comparison}

This new species is close to $A$. (A.) instriata sp. nov., but differs in many respects: asymmetrical glands are located above on the posterior margin of valves; shell with concentric striations and cross lines between these striations, and without middle lens-like structure on the surface; frontal organ is larger and pointed at the tip; dorsal margin on the 3rd segment of the mandible endopodite is with distal ledge; on the 1st and 2nd segments of the mandible in female are placed less ventral setae, and there is smaller main middle claw-seta on the 3 rd segment there are more setae on the 1st segment of the maxilla; the distodorsal seta on the 1st segment, the main middle claw-seta on the 3rd segments of the 5 th limb, and distodorsal seta on the 1 st segment of the exopodite of the 6th limb are shorter; furca is with unpaired bristle.

\section{Distribution}

Collected only in subtropical surface water of the north-western Pacific $\left(33-34^{\circ} \mathrm{N}\right.$ and $\left.139-140^{\circ} \mathrm{E}\right)$ from $100-0 \mathrm{~m}$.

\section{Archiconchoecia (Archiconchoeca) striata Müller, 1894}

Archiconchoecia striata Müller, 1894: 225, Taf. 6, Fig. 31-46, Taf. 8, Fig. 34; 1906: 45, Taf. 7, Fig. 13-17; 1908: 63; 1912: 56; Schweiger, 1912: (cit. on Gooday, Angel, 1977); Gamulin, 1948: (cit. on Gooday, Angel, 1977); Hure, 1961: 11, 54, Sl. 6, 7, Tab. 2; Grice, Hart, 1962: 302; Puri, 1963: 2 (list); Leveau, 1965: 178; 1967: 67, 1969: 129, 130, 131, 136, 138, 140; Deevey, 1968: 23, fig. 4; 1970: 801; 1971: 231; 1974: 358; 1978b: 57, 59, tab. 1, 2; 1982: 469, 470; Deevey, Brooks, 1980: 59-61, tab. 2-4; Vucetic, 1977; (cit. on Gooday, Angel, 1977); Alcaraz, Manriques, Vasquez, 1975: 382, 383, 384, Fig. 1: 16, 17; Alcaraz, 1977: 5, 23; Angel, Fasham, 1975: 727, 736, fig. 5, tab. 2-4; Angel, 1979: 81-82; 1981: 556, 561 (part); Gooday, Angel, 1977: 140, 144, 146; Moraitou-Apostolopoulou, 1981: 175, 176, fig. 3; Gonzales, Breman, 1982: 204, 205, 206; Drapun, 1981: 75; 1983: 34; Benassi, Ferrari, Rossi, Sei, Angel and McKenzie, 1998.

Not Archyconchoecia striata: Chavtur, 1977a: 142, 157, 158, fig. 8, tab. 6; 1977b: 31, tab. 2 (list); 1977c: 19, tab. 2 (list); 1991: 47.

Not Archiconchoecia striata: George, 1979: 123-127, figs. 1-16; George, Nair, 1980: 31, 41, fig. 6; Angel, 1981: 556 (part), 561 (part), fig. 194 (6 A-H); Chavtur, 1992: tab. 2 (list).

\section{Material examined}

Adult female (in poor condition), R/V “Lomonosov”, station 466, $22^{\circ} 19 \mathrm{~N} 61^{\circ} 02 \mathrm{~W}$, in tow from 2600-0 m, 2 October 1959.

\section{Distribution}

This species is known from tropical - subtropical zone of the Mediterranean Sea (Müller, 1894; Schweiger, 1912; Gamulin, 1948; Hure, 1961; Grice and Hart, 1962; Puri, 1963; Leveau, 1965; 
Vucetic, 1970; Alcaraz, 1977; Gooday and Angel, 1977; Moraitou-Apostolopoulou, 1981; Benassi et al., 1998) and Atlantic Ocean within latitudes $36^{\circ} \mathrm{N}-42^{\circ} \mathrm{S}$ (NE Atlantic - Müller, 1906; Alcaraz, et al., 1975; Alcaraz, 1977; Angel and Fasham, 1975; Angel, 1979; 1981. NW Atlantic - Deevey, 1968; 1970; 1971; 1978b; 1982; Deevey, Brooks, 1980; Angel, 1979; 1981; Gonzales and Breman, 1982. S. Atlantic - Müller, 1906; 1908; Deevey, 1974; Angel, 1981; Drapun, 1981; 1983).

Archiconchoecia striata was found at levels between the surface and $1000 \mathrm{~m}$ with mostly in the upper $500 \mathrm{~m}$ (Deevey, 1978b; Deevey and Brooks, 1980) and (as exclusion) 1 juvenile was recovered from $2700-2400 \mathrm{~m}$ (Müller, 1906). This species was captured also in tows from $3000-0 \mathrm{~m}$. Besides that, it is known in the Indian Ocean $\left(7-34^{\circ} \mathrm{N}\right.$ and $27-32^{\circ} \mathrm{S}$ ) between the surface and $400 \mathrm{~m}$ (Müller, 1906; 1908; Leveau, 1967; 1969).

\section{Archiconchoecia (Archiconchoecia) aff. striata 1}

Archiconchoecia striata: George, 1979: 123-127, figs. 1-16; George and Nair, 1980: 31, 41, fig. 6.

Remarks

This species distinctly differs from Müller's description in small rostrum on the shell, suture on the frontal organ, thin exopodite, short filaments, and strongly curved right clasper on the 2nd antenna, and only one seta on the mandible exopodite.

\section{Distribution}

Collected in the epipelagial of the Indian Ocean within latitudes $4-24^{\circ} \mathrm{N}$. Probably, specimens noted by Müller $(1906,1908)$ and Levean $(1967,1969)$ from this ocean also belong to $A$. (A.) aff. striata 1 .

\section{Archiconchoecia (Archiconchoecia) aff. striata 2}

Archiconchoecia striata: Angel, 1981: 556 (part), 561 (part), fig. 194 (6 A-H).

\section{Remarks}

This species is separated from Müller's description by prolonged rostrum on the shell, and very small size of " $a$ " and " $b$ " bristles on the 2 nd antenna (Angel' s publication contains only information for the shell and 1st and 2nd antenna).

Distribution

Atlantic Ocean (precise locality is unknown).

\section{Archiconchoecia (Archiconchoecidia) Chavtur subgen. nov.}

Composition

This subgenus contains only $A$. (A.) apertesulcata $\mathrm{n}$. sp.

\section{Description}

Shell. Valves of both sexes are prolonged. Rostrum is relatively developed. Rostral incisure is barely noticeable. Posterior margin is with one small knob-like tubercle on each valve.

Second antenna. The exopodite is thin and longer than the protopodite. Basal segment of the endopodite has bare surface. The right clasper is with short base and with terminal thickening. The left clasper is straight and shorter than the right one. The 5 filaments placed on the distal segment of the endopodite in male are longer than protopodite.

Mandible. The exopodite is represented by one long seta. All dorsal setae borne on the 2nd segment and 2 dorsal setae on the 3 rd segment of the exopodite are usual type. 
Fifth limb. The 1 st segment of the exopodite bears 7 ventral and 3 dorsal setae.

Sixth limb. The 1st segment of the exopodite is armed with 5 ventral setae.

Copulatory appendage. The blunt protuberance is placed at the tip.

\section{Archiconchoecia (Archiconchoecidia) apertesulcata Chavtur sp. nov.}

(Figs. 7-10 and 11, D-G)

Archyconchoecia striata: Chavtur, 1977a: 142, 157, 158, fig.8, table 6; 1977b: 31, table 2 (list); $1977 \mathrm{c}$ : 19, table 2 (list): 1991: 47.

Archiconchoecia striata: Chavtur, 1992: table 2 (list).

Material examined

Holotype. N1106 - adult male, length 0.85 and height $0.34 \mathrm{~mm}$, appendages are mounted on slide and valves remained in alcohol. In collection of the Museum of Institute of Marine Biology, Vladivostok, Russia (together with paratypes). Type-locality - R/V “Vityaz", station 5635, $44^{\circ} 25 \mathrm{~N}$, $149^{\circ} 10 \mathrm{E}$, depth 4000-3000 m, 28 August 1966 (Plankton Bogorov-Rass's Net, $\mathrm{S}=1,0 \mathrm{~m}^{2}$ ).

Paratypes. 1107 - adult male (length 0.85 and height $0.50 \mathrm{~mm}$ ), 1108 - adult female (length 0.82 and height $0.50 \mathrm{~mm}$ ), 1109 - adult female (length 0.85 and height $0.50 \mathrm{~mm}$ ) from the same sample as holotype. Appendages of all specimens are remained on slides and valves in alcohol.

Additional specimens - R/V "Vityaz" : 3 adult males, length $0.85 \mathrm{~mm}$, from the same sample as holotype; one adult female, length $0.85 \mathrm{~mm}$, station and date as holotype, depth 3000-2500; 2 adult females, length $0.82-0.84 \mathrm{~mm}$, station 5610, $48^{\circ} 48 \mathrm{~N}, 153^{\circ} 18 \mathrm{E}$, depth $3000-2500 \mathrm{~m}, 23$ July 1966 .

All material including holotype and paratypes were caught by Plankton Bogorov-Rass's Net $\left(\mathrm{S}=1,0 \mathrm{~m}^{2}\right)$.

\section{Etymology}

The specific name "apertesulcata", from the Latin "aperte" [=distinctly] and "sulcata" [=grooved, lined], refers to sculpturing of the shell.

\section{Description of adult male}

Shell (Fig. 7, A, B). Length is $0.85 \mathrm{~mm}$. Valves are slightly prolonged. Height of shell is 56$58 \%$ of the length. Greatest height is at the posterior part. Rostrum is wide and relatively developed, and there rostral incisure is barely noticeable. Dorsal margin with is distinct medial indentation. Numerous varisized glands are placed along anterior and ventral margins. Posterior margin is evenly rounded and with a small knob-like tubercle on each valve (there placed asymmetrical gland). Left and right asymmetrical glands on the valve are approximately at 70 and $60 \%$ of the way up the posterior margin respectively. Shell is with concentric striations.

Frontal organ (Fig. 7, C, D). It slopes downward, extends beyond curved distal segments of the 1 st antenna, and is nearly equal the length of the dorsal side of the 1st antenna. Capitulum section is unseparated, rounded at the tip, without hairs and spinules and thicker than stem.

First antenna (Fig. 7, D). The limb is 6 - jointed. Dorsal seta of the 2 nd segment is long, slim and armed with spinules. The 5th and 6th segments are with long filaments of equal length, distally widened and pointed at the tip. Dorsal margin of the limb is about $60 \%$ of the filaments length. Height of antenna (on the 2nd segment) is approximately $20 \%$ of the length. The 1 st segment is slightly thicker than the 2 nd segment and almost $1 / 4$ as long as it. There are few dark pigment spots on the 1st segment.

Second antenna (Fig. 7, E-G). The exopodite is thin, approximately equal in thickness along the shaft and is about $110 \%$ length of the protopodite. The total length of the 2 nd-9th segments of the exopodite is about $30 \%$ length of the 1 st segment. Basal segment of the endopodite has a surface, and bristles " $a$ " and " $b$ " are The bristles " $c$ " and " $b$ " on the 2 nd segment are of usual type. The right 


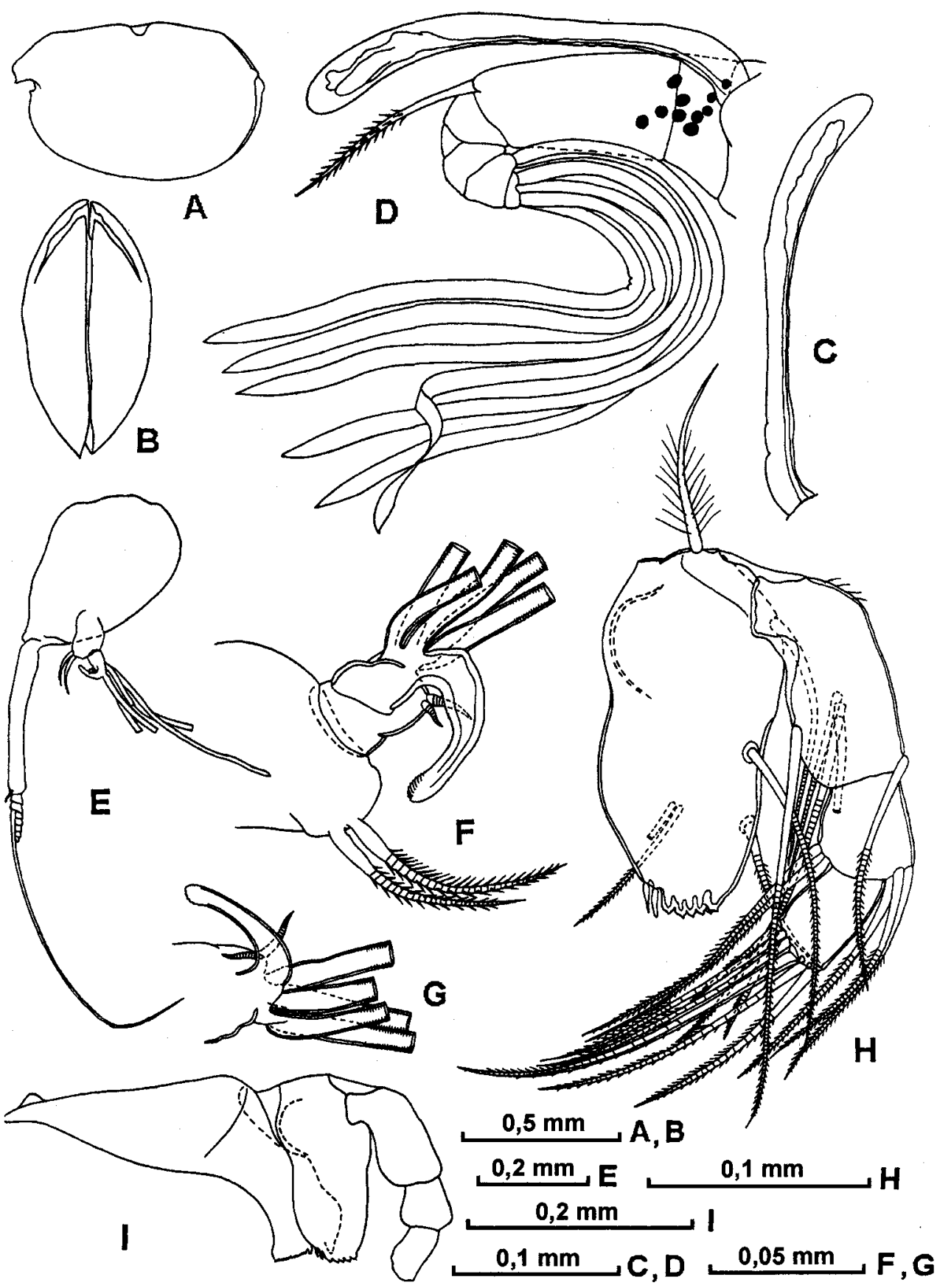

Fig. 7 Archiconchoecia (Archiconchoecidia) apertesulcata sp. nov. (male: 1107 - A, B, D; 1106 -C, E-I) $A$ and $B$ - lateral and ventral views of shell, C - frontal organ, D - frontal organ and 1st antenna, E - 2nd antenna, $\mathrm{F}$ and $\mathrm{G}$ - left and right endopodites of 2 nd antenna, $\mathrm{H}$ and $\mathrm{I}$ - mandible. 


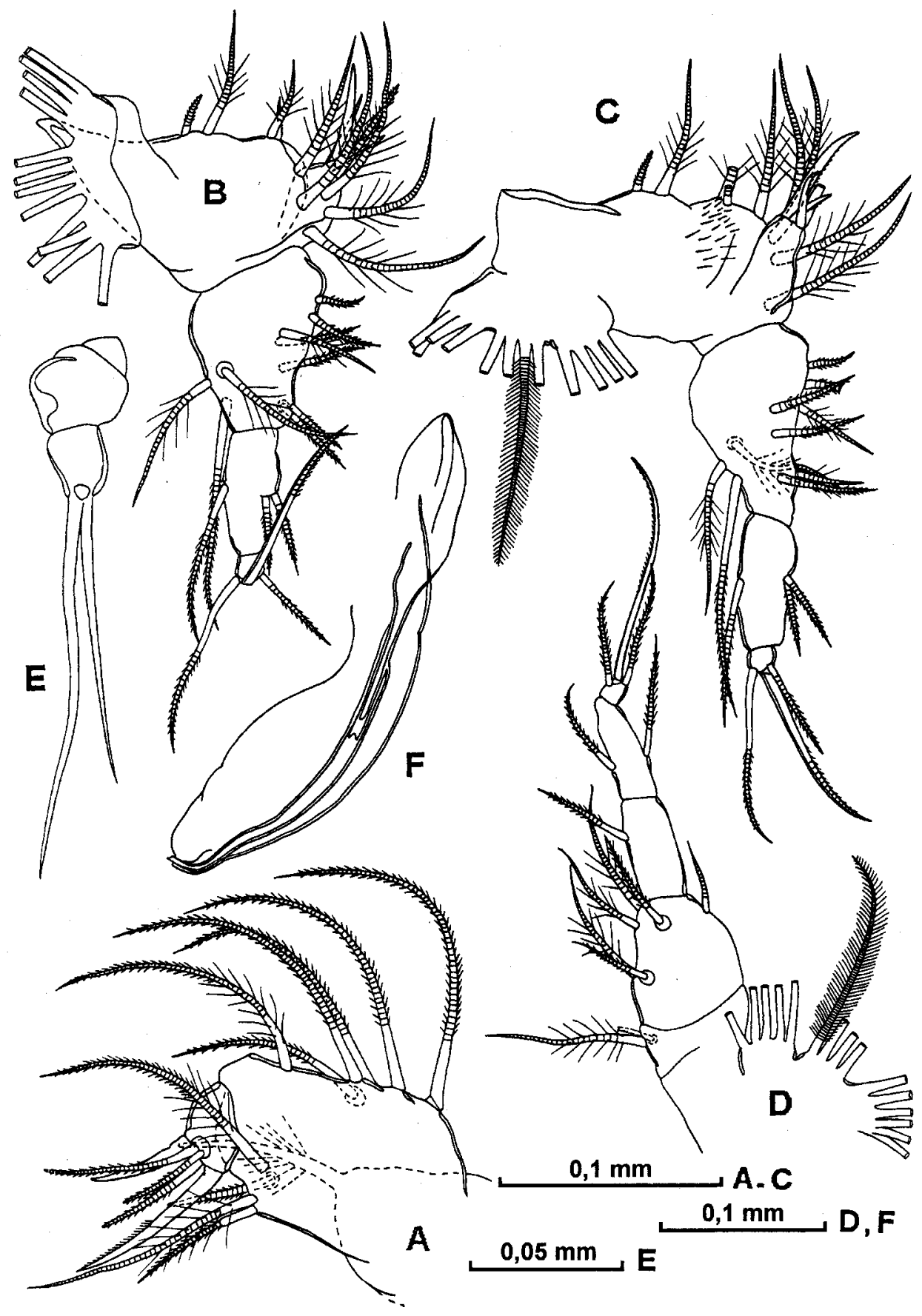

Fig. 8 Archiconcoecia (Archiconchoecidia) apertesulcata sp. nov. (Male: $1106-1-5 ; 1107$ - 6) A maxilla, B and C - fifth limb, D - sixth limb, E - seventh limb, F - penis. 


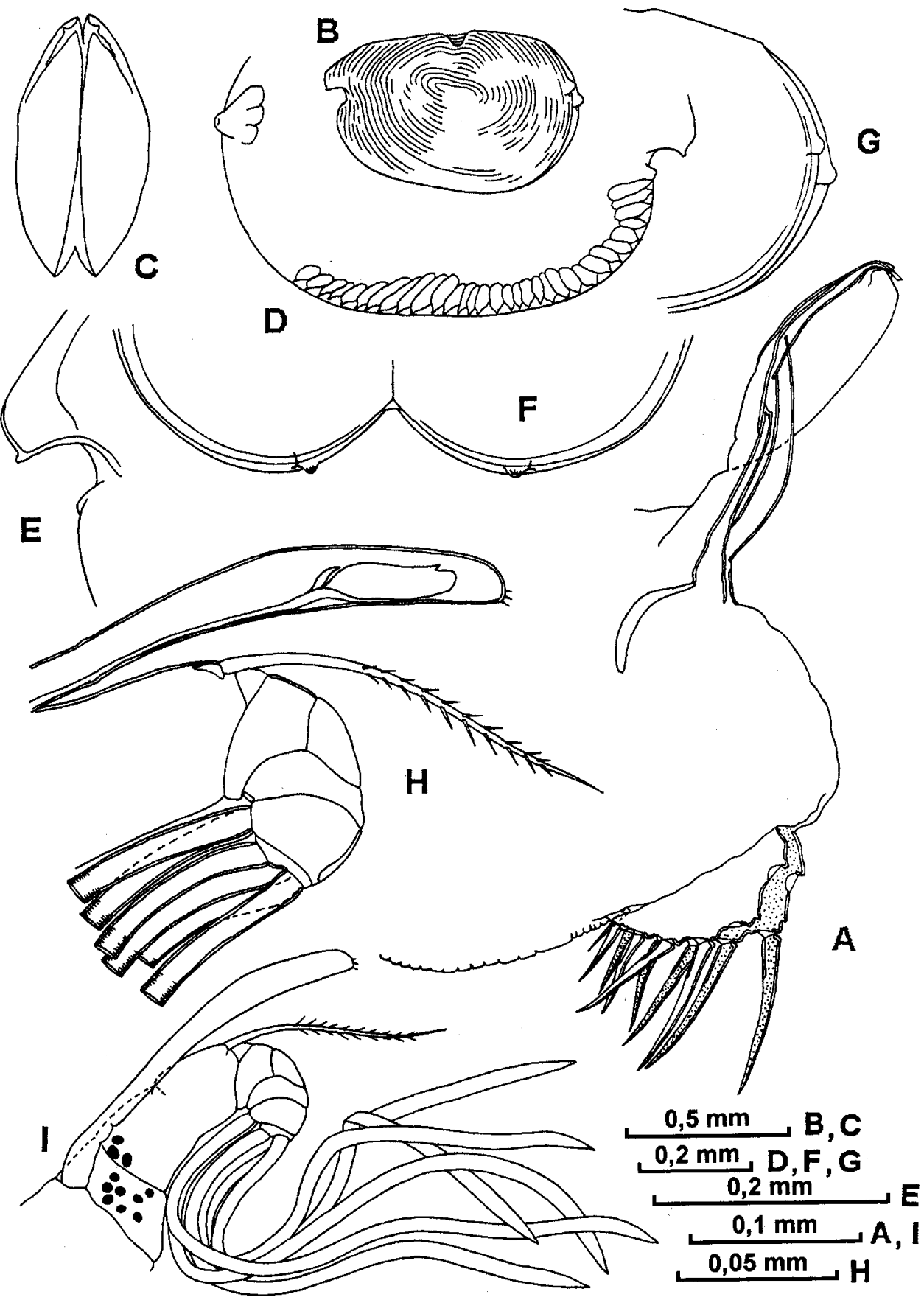

Fig. 9 Archiconchoecia (Archiconchoecidia) apertesulcata sp. nov. (male: 1106- A, D, F, female 1109 B, C, E, G-I) A- furca and penis, B and C - lateral and ventral views of shell, D - margin of right valve, $\mathrm{E}$ - anterior part of left valve, F and G - posterior part of shell, $\mathrm{H}$ and $\mathrm{I}$ - frontal organ and 1 st antenna. 


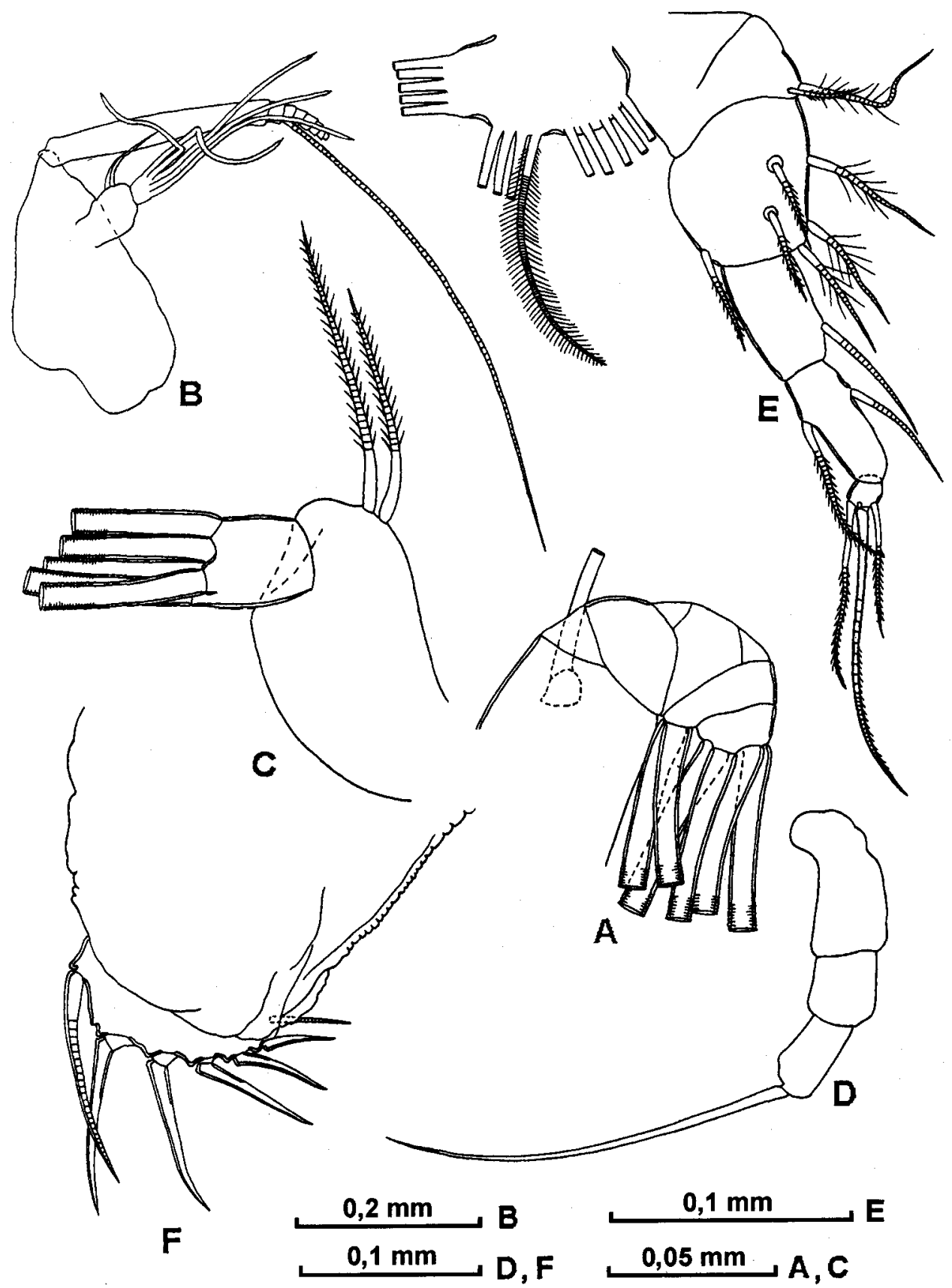

Fig.10 Archiconchoecia (Archiconchoecidia) apertesulcata sp. nov. (female: 1109 - A, B, D-F, 1108 -C) A - distal part of 1st antenna, B - 2nd antenna, C - endopodite of 2nd antenna, A - endopodite of mandible, E - sixth limb, F - furca. 
clasper is thick in the middle (about 1.5 times thicker than its base), has a short base and tapers towards the tip. The left clasper is developed, straight, with terminal thickening, shorter and thinner than the right one. All the filaments borne on 2 nd segment are equal in length, slightly widened in the middle part, rounded and have spinule at the tip, and are approximately as long as the exopodite and protopodite.

Mandible (Figs. 7, H, I and 11, D). The epipodite is well developed and lacks bristle. The exopodite is represented by one long seta. The 1st segment of the endopodite has slightly tuberous dorsal margin and is armed with one dorsal and 4 ventral (one short and 3 long) setae, and the 2nd
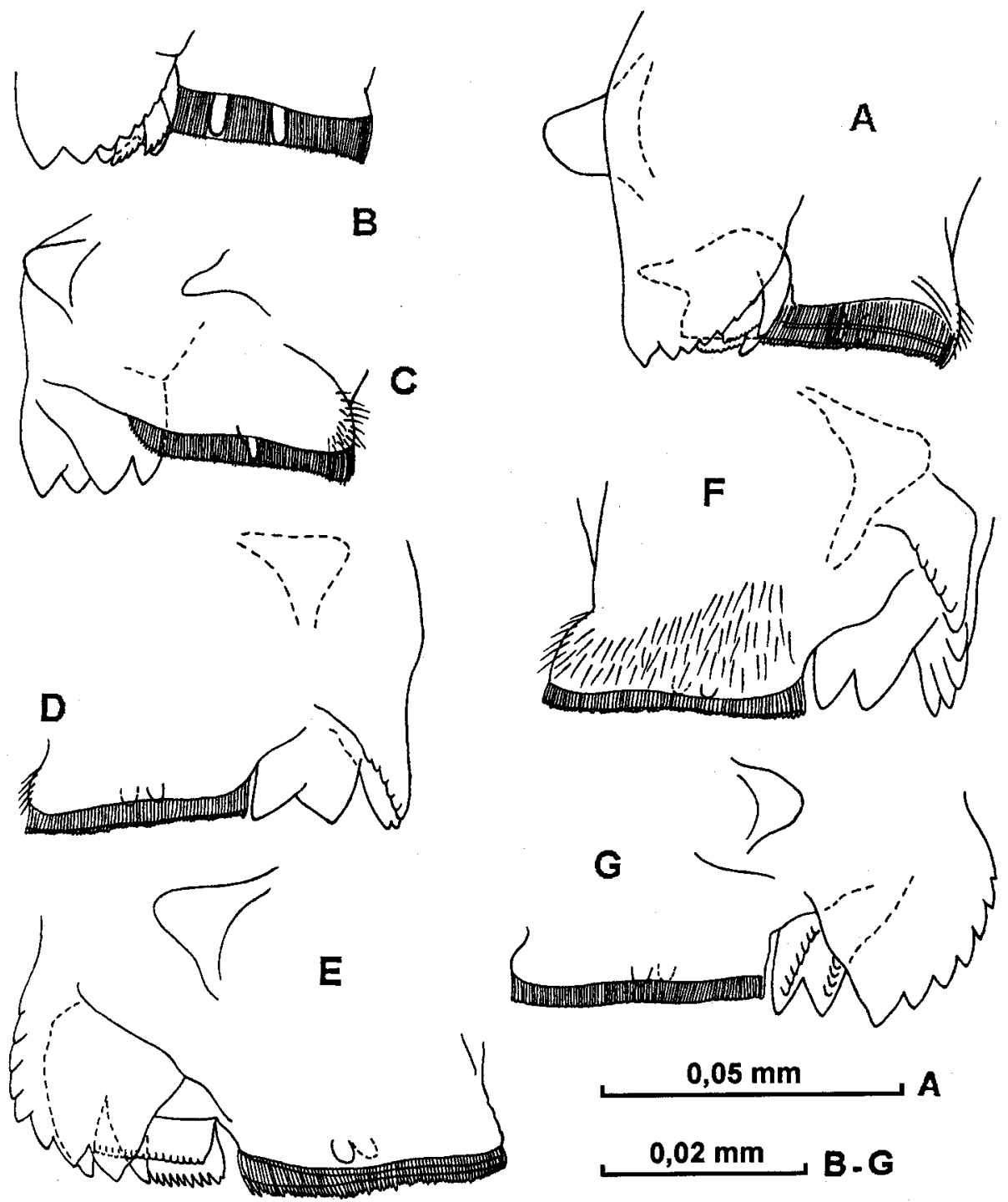

Fig. 11 Archiconchoecia (Archiconchoecidia) instriata sp. nov. (male: $1100-$ A), A. (A.) propinqua sp. nov. (female: 11105 - B and C), A. (Archiconchoecidia) apertesulcata (male: 1106 - D , female: 1108 - E, female: No. $1109-F, G)$ A-G - toothrows and masticatory pad of coxa of mandible. 
segment is with 3 slight dorsal and 2 usual long ventral setae. The 3rd segment has straight dorsal margin and bears 7 setae, longest seta of which is claw-like and shorter than the endopodite (on the dorsal side); the 1 st dorsal seta is longer than the 2 nd seta. Basale is armed with 2 anterior and 2 lateral setae, one anterolateral seta, and the anterior row of the hairs are near the articulation. Basal entite has toothrow with 6 distinctly separated triangular teeth and 2 short proximal bristles. Coxal endite bears 3 closely set toothrows. Numerous thin ventral spines are borne on the flat masticatory pad.

Maxilla (Fig. 8, A). The basal segment (of the endopodite) bears 6 anterior (one plumose), 3 posterior ( 2 plumose), and one medial, setae. The distal segment is armed with 2 claw-like and 3 usual setae.

Fifth limb (Fig. 8, B, C). The epipodite has 3 groups of $4+4+4$ plumose setae.

The 1st segment of the exopodite bears 7 ventral ( 2 plumose) and 3 dorsal ( 2 plumose) setae, of which the distodorsal seta is about $75 \%$ length of the exopodite (on the dorsal side). The 2 nd segment is with 2 ventral and one dorsal setae, and the last seta is approximately $50 \%$, and the middle claw-seta of the 3 rd segment is about $60 \%$ the length of the exopodite. The dorsal and middle terminal clawsetae are subequal in length. No hairs are recorded the limb.

Sixth limb (Fig. 8, D). The epipodial appendage has 3 groups of the $5+4+6$ plumose setae. One long plumose and one short nonplumose setae are borne on the endopodite. The 1st segment of the exopodite has one dorsal and 5 ventral ( 3 plumose) setae. The 2 nd segment is armed with one ventral seta and the 3rd one with one long dorsal and one short ventral setae. Two usual setae and one middle claw-seta are placed on the 4th segment. Last claw-seta and dorsal seta of the 1st segment are about $70 \%$ and $40 \%$ length of the exopodite (on the dorsal side) respectively.

Seventh limb (Fig. 8, E). It is short and thick (65\% of the length), and is about $40 \%$ length of its longest seta. The short seta is $75 \%$ length of the long one.

Copulatory appendage. (Figs. 8, F and 9, A). It is tapering towards the base and tip from the middle. The greatest height is at the middle. The rounded tip is with blunt tubercle. No muscles are noted on the penis.

Caudal furca (Fig. 9, A). This limb has 6 slim and long paired claws and single unpaired bristle.

Description of adult female.

Shell (Fig. 9, B-G). Length is 0.82-0.85 mm.

Frontal organ (Fig. 9, H, I). Capitulum section bears some terminal hairs (or spinules?).

First antenna (Figs, 9, H, I and 10, A). The 1 st segment is about $1 / 3$ as long as the 2 nd segment.

Second antenna (Fig. 10, B, C). The endopodite is without "c"-"e" bristles. The terminal filaments are equal in thickness (along the entire length) and about $3 / 4$ the length of the protopodite and exopodite.

Mandible (Figs. 10, D and 11, E-G). Main terminal claw-seta is longer than the endopodite (on the dorsal side).

Maxilla and fifth limb. As in male.

Sixth limb (Fig. 10, E). The epipodial appendage has 3 groups of the $5+4+5$ plumose setae. Dorsal seta of the 1st segment is about $30 \%$ length of the exopodite (on the dorsal side).

Seventh limb and Caudal furca (Fig. 10, F). As in male.

\section{Comparison}

New species sharply differs from all the other species of this genus in having a rostral incisure and tubercles on the posterior margins of the shell. Its exopodite is thin and longer than protopodite on the 2nd antenna. Claspers on the 2nd antenna have a short base and terminal thickening, and its filaments are longer than protopodite in male. Mandible bears only one seta on the exopodite and usual (not claw-like) dorsal setae on the 2nd and 3rd (setae near dorsal margin) segments of the endopodite. This new species is also differs from other by the number of setae on the 5th and 6th 
limbs and the presence of blunt protuberance at the tip.

Distribution

This species was caught only in the region of Kurile-Kamchatka Trench from $2500-4000 \mathrm{~m}$.

Archiconchoecilla Chavtur gen. nov.

Type-species - Archiconchoecia maculata Chavtur, 1977.

Composition

This genus contains only 2 species: A. maculata (Chavtur, 1977) and A. versicula (Deevey, 1978).

\section{Description}

Shell. Male and female range from 0.8 to $1,4 \mathrm{~mm}$ in length. Valves are slightly prolonged. Height of shell in male and female is $52-56 \%$ and $52-55 \%$ of the length respectively, and approximately equal at the anterior and posterior parts. Rostrum is developed, and there is only a slight rostral incisure. Dorsal and ventral margins are straight or nearly straight. Anterior and posterior margins are rounded (posterior part of the right valve in A. maculata is unrounded). Posterior margins of the right and left valves are asymmetrical at the upper half: left margin is slightly extended beyond right margin. Left and right asymmetrical glands are about $80-90$ and $60-70 \%$ of the way up the posterior margin respectively. These glands open on tiny tubercles. The surface of the shell is sculptured with wavy lines or with varying shape cells (reticulated).

Frontal organ. It is straight or slightly down-curved, short or middle length, and barely or considerably extended beyond the down-curving distal segments of the 1st antenna. Organs in male and female are approximately $90-110 \%$ and $80 \%$ of the length of the dorsal side of the 1st antenna respectively. Capitulum section is unseparated, rounded at the tip (slightly pointed in $A$. versicula on Angel, 1981).

First antenna. The limb is 6-jointed, with one dorsal seta placed on the 2nd segment. This seta long, slim and armed coarsely with short hairs or spinules. The 5th and 6th segments bear 6 long filaments in equal length, slightly widened towards the tip or unwidened and pointed or rounded at the tip. Dorsal margin of the limb is $58-60 \%$ of the filaments length. Height of antenna (on the 2 nd segment) is less $20 \%$ (17\% in all species) of the length. Hairs are placed dorsally on the 4th segment. The limb has numerous dark pigment spots.

Second antenna. The exopodite is thin, equal in length or longer than the protopodite. The total length of the 2nd-9th segments of the exopodite is approximately $35-45 \%$ length of the 1 st segment. Basal segment of the endopodite bears long hairs (female A.versicula unknown) and without warty surface. Its 2nd segment is armed with long hairs in female and with bristles " $c$ " and " $d$ " in male. The right clasping organ is slightly thick. The right and left claspers distally are not tapering, with or without usual terminal thickening and rounded at the tip. The filaments of the 2 nd segment have an equal thickness throughout, and pointed at the tip. One or two proximal filaments are slightly longer than the 3 others, protopodite and exopodite.

Mandible. The epipodite is without bristles. The exopodite is represented by one long seta. The 1st segment is armed with one dorsal and 4 ventral setae; the 2nd segment with 3 dorsal and 2 ventral setae; the 3rd segment has 7 setae, the largest of which is claw-like and 2 first dorsal setae are slight (the 1st shorter than 2nd dorsal seta). Main claw-seta borne on the 3rd segment is longer than the exopodite (on the dorsal side) in female, and shorter in male. Basale is armed with 2-3 anterior, 2 lateral and 1 anterolateral setae and anterior row of the long hairs near the articulation. Basal endite has toothrow with 6 distinctly separated triangular teeth (in addition to one lateral tooth in $A$. maculata) and 2 short posterior bristles.

Maxilla. The basal segment of the endopodite bears 6 anterior and 4 posterior setae. The 2 nd segment has 2 claw-setae and 3 usual setae. 
Fifth limb. The epipodial appendage has 3 groups of $4+4+4$ plumose setae. The 1 st segment of the exopodite bears 6-7 ventral and 3 dorsal setae, and 2 nd segment is with 1-2 ventral and one dorsal setae. The middle claw-seta of the 3rd segment is about $60 \%$ the length of the exopodite (on the dorsal side) and approximately as long as its dorsal seta.

Sixth limb. The epipodial appendage has 3 groups of $4(5)+4+5(6)$ plumose setae (13-15 totally) in male and $4(?)+4+4$ in female. One long plumose seta is borne on the endopodite. The 1 st segment of exopodite is with 1-2 dorsal and 4-5 ventral setae, the 2nd segment is only with one ventral, and 3rd segment is with one dorsal and one ventral setae. The middle claw-seta of the 4th segment is longer than its 2 usual setae, and is $75-80 \%$ the length of exopodite in male and $75 \%$ in female. The distodorsal seta of the 1 st segment is $35-80 \%$ the length of the exopodite (on the dorsal side). Height of the exopodite is approximately $25-35 \%$ of its length.

Seventh limb. It is thick and prolonged (50\% of its length) in A. maculata and short (25\%) in A. versicula. The limb is about $30 \%$ of the longest seta in length (this seta is broken in A. versicula).

Copulatory appendage. It is tapering towards the base and tip from the middle. The greatest height is at the middle and approximately $30-40 \%$ of the length (from tip to dorsomedial indentation). The tip is rounded.

Caudal furca. This limb has 6 or 8 pairs of claws and with or without unpaired bristle.

\section{Comparison}

New genus differs from all the other genera in the following respects: posterior margins on the right and left valves are asymmetrical at the upper half; the exopodite of the 2 nd antenna is longer than the protopodite; the exopodite of the mandible is represented only by one long seta, and its endopodite is armed with usual dorsal setae.

This genera is close to Archiconchoecinna gen. nov., but separated (in addition to the above mentioned) by equal height in the anterior and posterior halves of the shell, triangular teeth on the basal endite of the mandible, less number of the posterior setae placed on the 1st segment of the endopodites of the maxilla and of the 6th limb, longer distodorsal seta on the 1st segment of the exopodite of the 5th limb, and longer middle-terminal seta on the 6th limb.

\section{Distribution}

Members of the genus Archiconchoecilla were collected in the North Pacific, North Atlantic and Southern Ocean (Pacific sector). The northernmost and southernmost latitude are $45^{\circ} \mathrm{N}$ and $44^{\circ} \mathrm{S}$. The known depth range of the genus is $1000-9500 \mathrm{~m}$.

\section{Key to Species of Genus Archiconchoecilla (Adult Male and Female)}

1. Shell length is over $1 \mathrm{~mm}$, sculpture is represented by varying shape cells, furca has 8 pairs of claws

A. maculata (Chavtur)

Shell length is less than $1 \mathrm{~mm}$, sculpture is represented by wavy lines, furca has 6 pairs

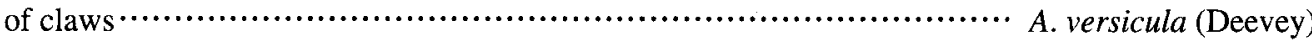

\section{Archiconchoecilla maculata (Chavtur, 1977)}

(Figs. 12-16)

Archyconchoecia maculata Chavtur, 1977a: 140-142, 155, 158, 160, figs. 3c-d, 4a-d; 1977b: table 2; 1977c: tabl. 2; 1991: 42.

Archiconchoecia maculata Chavtur, 1992: table 2 (list).

Material examined

Holotype. 1110 - (1526 - obsolete number) adult male, length $1.4 \mathrm{~mm}$, appendages are mounted 
on slide and valves preserved in alcohol. In collection of the Museum of Institute of Marine Biology, Vladivostok, Russia (together with paratypes). Type-locality- R/V "Vityaz", station $5262,45^{\circ} 11 \mathrm{~N}$ and $152^{\circ} 28 \mathrm{E}$, depth 9500-7280 m, 24 August 1966 (Plankton Bogorov-Rass' s Net, $S=1.0 \mathrm{~m}^{2}$ ).

Paratypes. 1111 (1527 - obsolete number) -adult female (length $1.4 \mathrm{~mm}), 1112$ - adult female (1.3 $\mathrm{mm}), 1113$ - adult male $(1.4 \mathrm{~mm}), 1114$ - adult male $(1.4 \mathrm{~mm})$ from same sample as of holotype.

Additional specimens - 24 adult females, 20 adult males and 13 juveniles from sample as holotype.

Redescription of adult male

Shell (Fig. 12, A, B). The length is 1.2-1.4 mm. Valves are slightly prolonged. Height of shell is $52-53 \%$ of the length, and is equal at the anterior and posterior parts. Rostrum is developed and wide; there is only slight rostral incisure. Dorsal and ventral margins are straight. Posterior margins of the right and left valves are asymmetrical at the upper half, left margin is extended slightly beyond right margin. Left and right asymmetrical glands are approximately at 90 and $70 \%$ of the way up the posterior margin respectively. These glands are open on tiny tubercles. The surface of the shell is sculptured with varying shape cells.

Frontal organ (Fig. 12, C). It is straight, short, thicker at the proximal part and barely extends beyond the down-curving distal segments of the 1st antenna and it is approximately $90-95 \%$ of the dorsal side in length. Capitulum section is not separated, rounded at the tip and without hairs and spinules.

First antenna (Fig. 12, C-E). The limb is 6-jointed. Second segment has long, slim seta and is armed with short hairs. The 5th and 6th segments bear 6 long filaments equal in length, which are slightly widened towards the tip or not and pointed at the tip. Dorsal margin of the limb is nearly $60 \%$ the length of the filaments. Height of antenna (on the 2 nd segment) is about $17 \%$ of the length. The 1st segment is slightly higher than the 2 nd segment and approximately is $70 \%$ of its length. Long hairs are placed dorsally on the 4 th and 5 th segments. The 1 st and 2 nd segments have numerous dark pigment spots.

Second antenna. (Figs. 12, F, G and 13, A, B). The exopodite is thin (more thin in the middle part) and longer than the protopodite. The total length of the 2nd-9th segments of the exopodite is about $35 \%$ of the 1 st segment in length. Basal segment of the endopodite bears long hairs; the bristles " $a$ " and " $b$ " are very developed and The bristles " $c$ " and "d" placed on the 2nd segment are stout and spine-like type (bristle " $\mathrm{e}$ " is absent). The right clasper is curved and has terminal thickening; the base and the middle parts of this clasper are approximately equal in thickness. The left clasper is nearly straight and shorter than right one. Claspers are rounded at the tip. The 5 filaments on the 2nd segment are approximately equal in thickness lengthwise and pointed at the tip. One or 2 proximal filaments are longer than other 3, the protopodite and exopodite.

Mandible (Fig. 13, C-F). The epipodite is developed and without bristle. The exopodite is represented by one long seta ( 2 only in one limb). The 1st segment of the endopodite has almost straight dorsal margin and is armed with one dorsal and 4 ventral long setae; the 2nd segment has 3 dorsal and 2 ventral setae. The 3 rd segment bears 7 setae, of which main claw-setae is $77-81 \%$ of the endopodite in length (on the dorsal side) and 2 first dorsal setae are slight (the 1st one is shorter than the 2nd). Basale is armed with 2-3 anterior and 2 lateral setae and with one anterolateral seta and anterior row of the hair near the articulation. Basal endite has toothrow with 6 distinctly separated terminal and one lateral triangular teeth and 2 short posterior bristles. Coxal endite is armed with 3 closely set toothrows. Numerous thin ventral spines and lateral hairs are located on the flat masticatory pad.

Maxilla (Fig. 14, A-C). The basal segment of the endopodite bears 6 plumose anterior and 4 (of which 2 are plumose) posterior setae. The distal segment is armed with 2 claw-setae and 3 (only 4 in one limb of male) usual setae.

Fifth limb (Fig. 14, D, E). The epipodite is armed with 3 groups of $4+4+4$ plumose setae. The 


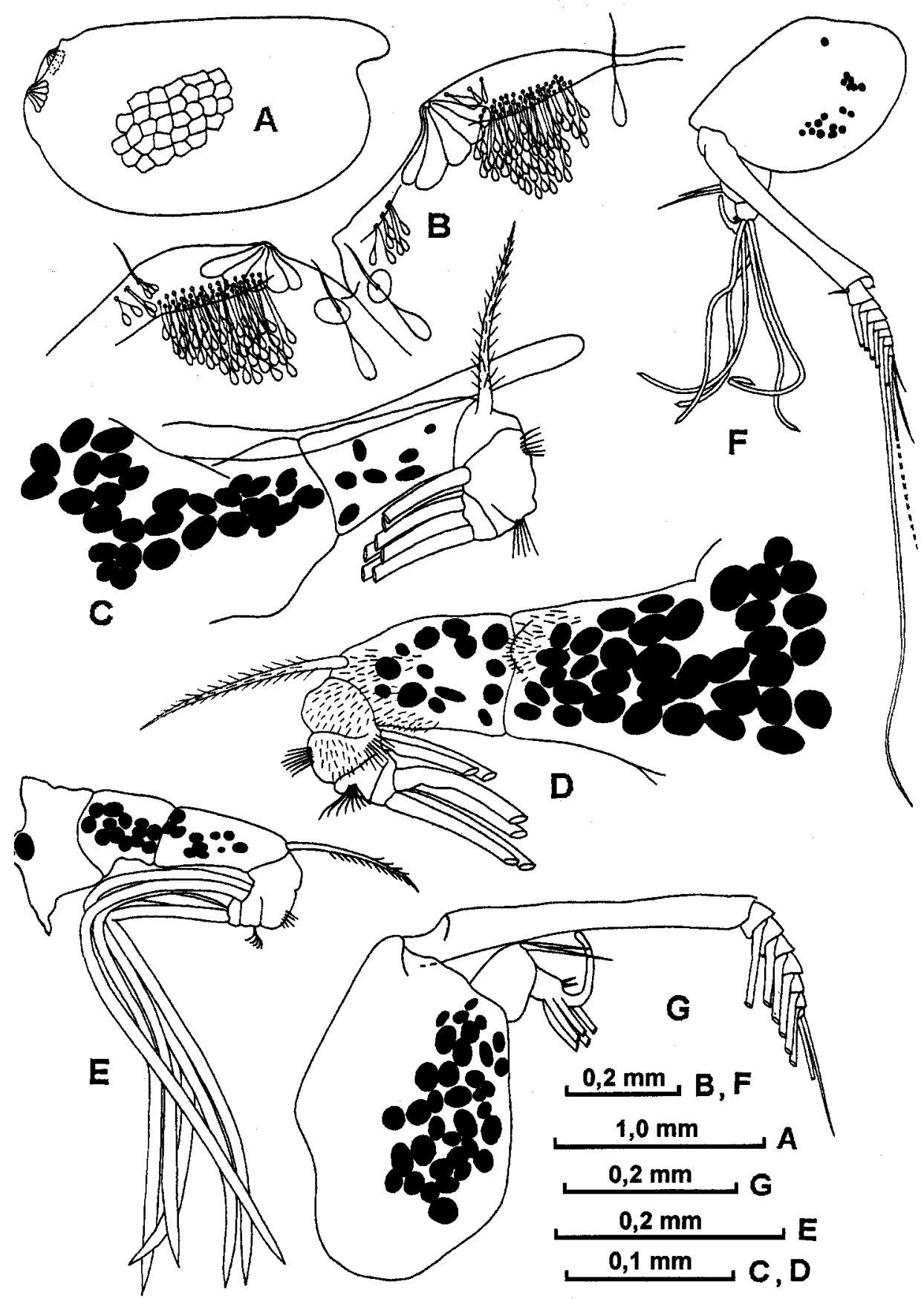

Fig. 12 Archiconchoecilla maculata (male: 1110 - A-D, G; 1113 - E; 1114 - F) A - lateral view of right valve of shell, B - posterodorsal part of shell, C - frontal organ and 1st antenna, D and E - 1st antenna, $F$ and $G$ - left and right 2 nd antenna. 


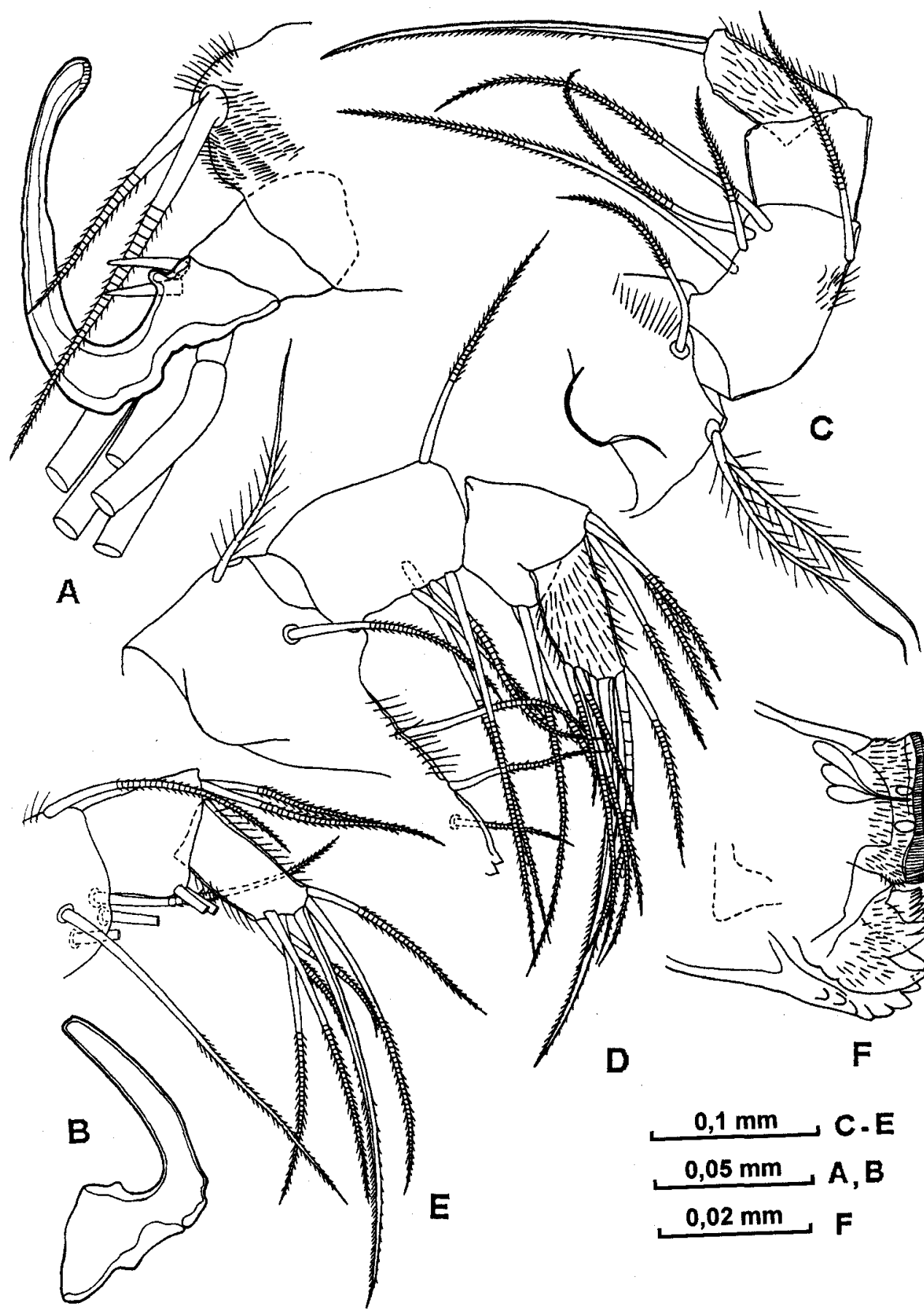

Fig. 13 Archiconchoecilla maculata (male: 1110 - A, B; 1114 - C, F; 1113 - D, E) A - right endopodite of 2nd antenna, B - left clasper of 2nd antenna, C and D - mandible, E - endopodite of mandible, F toothrows and masticatory pad of coxa of mandible. 


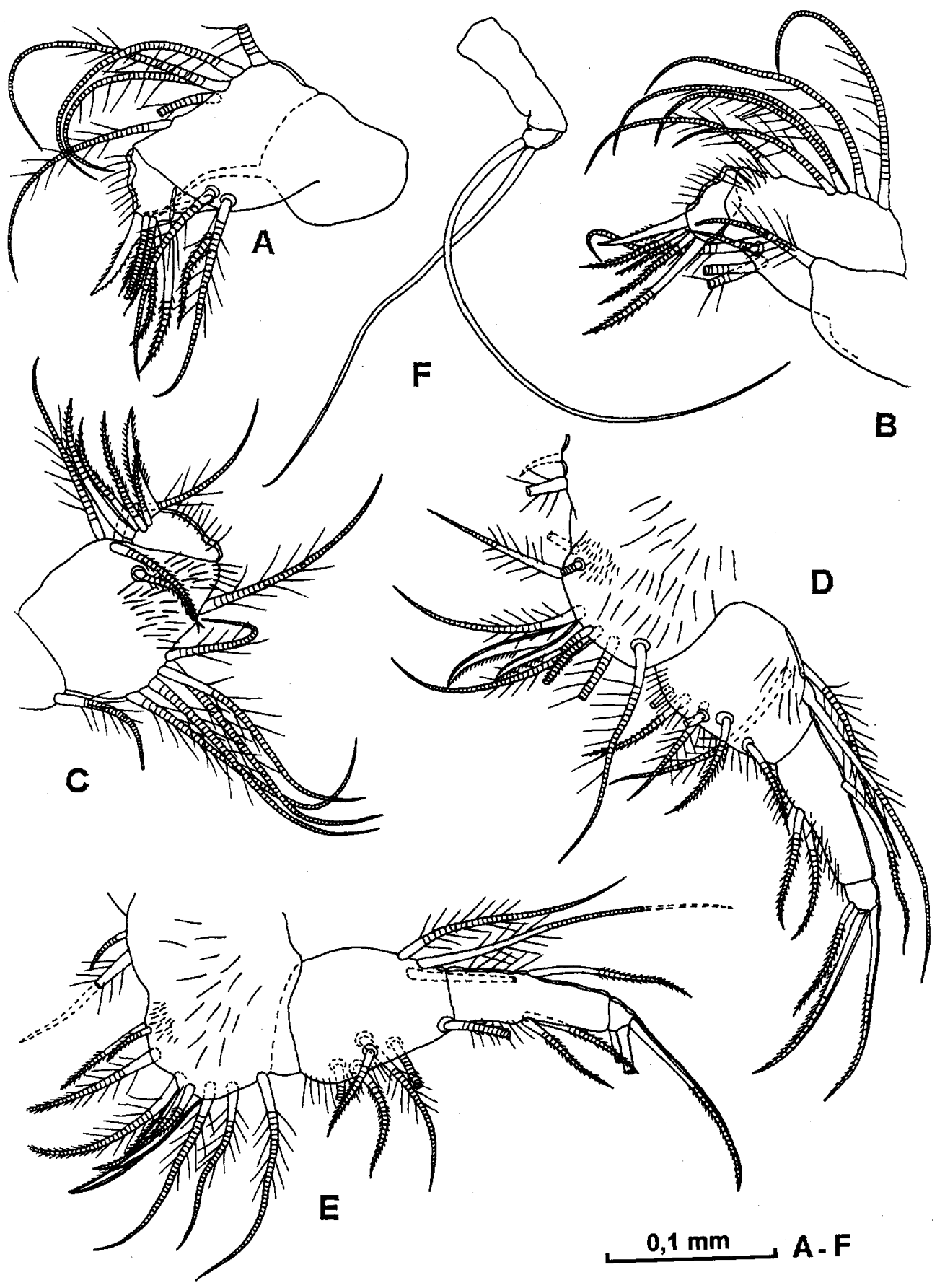

Fig. 14 Archiconchoecilla maculata (male: 1114 - A, B; 1113 - C, E, F ) A, B and C - maxilla, D and E fifth limb, F - sixth limb. 
1st segment of the exopodite bears 6 (one plumose) ventral and 3 (all plumose) dorsal setae, of which distodorsal seta is subequal (95-96\%) to the dorsal margin of the exopodite in length. The 2 nd segment is with 2 ventral and one dorsal setae; the last seta is about $50 \%$ and middle claw-seta of $3 \mathrm{rd}$ segment is $60 \%$ of the exopodite in length (on the dorsal side). The terminal dorsal and middle clawsetae are subequal in length. Dorsal and ventral sides of the 1st and 2nd segments bear long hairs.

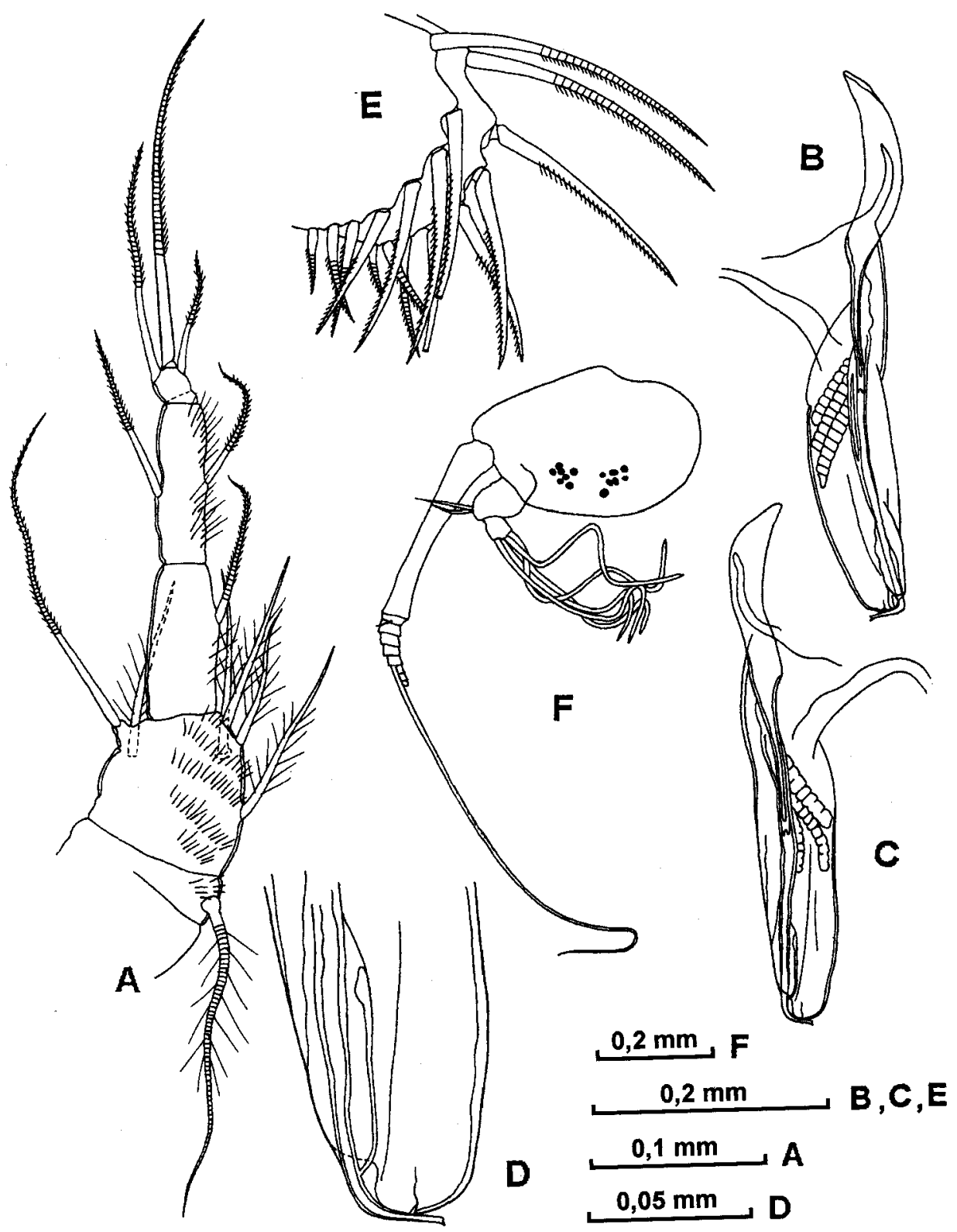

Fig. 15 Archiconchoecilla maculata (male: 1113 - A, B, D; male: 1114 - C, D, female: ${ }^{'} 1112$ - F) A sixth limb, B and C - penis, D - distal part of penis, E - furca, F - 2nd antenna. 


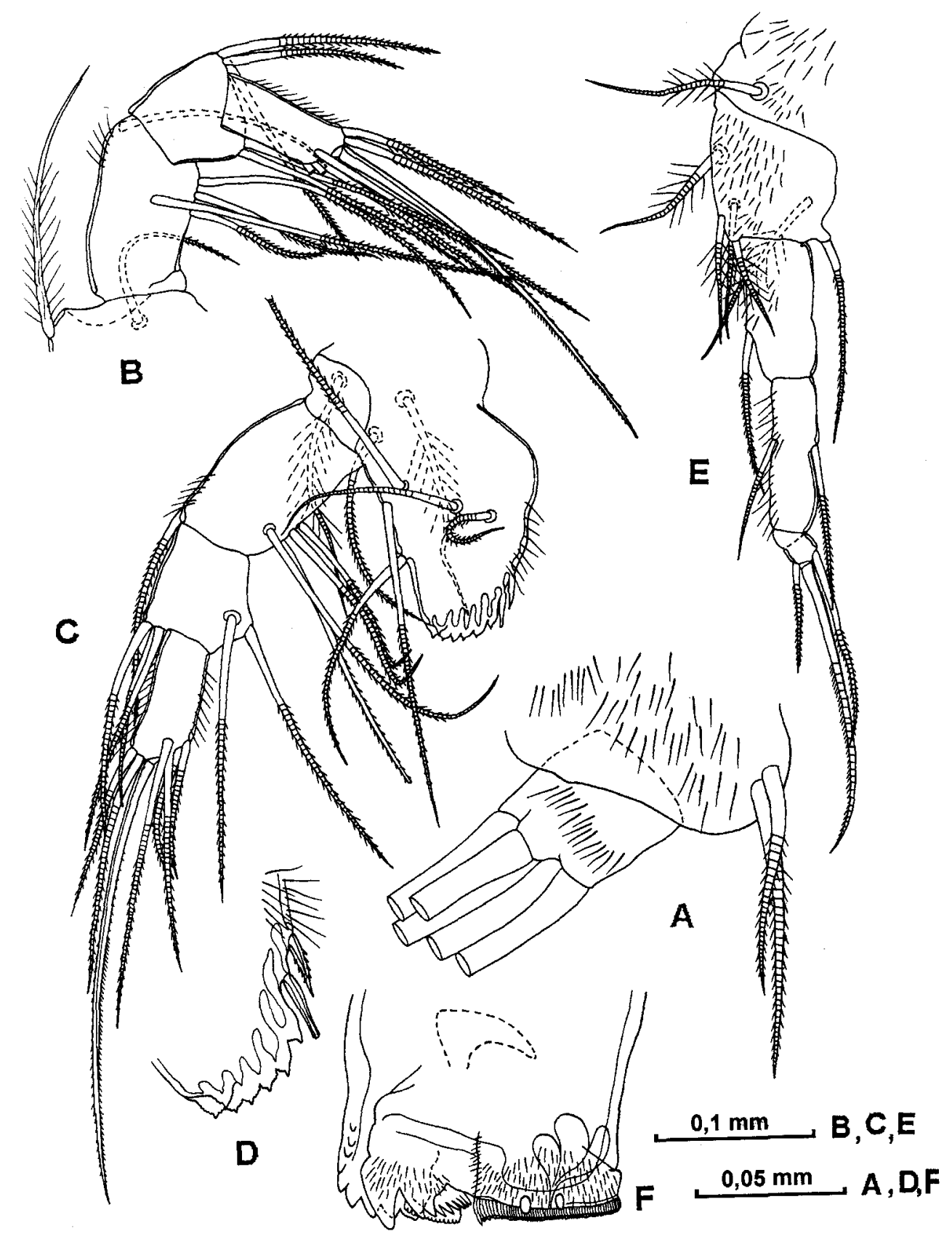

Fig. 16 Archiconchoecilla maculata (female: 1111 - A; 1112 - B-F) A - endopodite of 2nd antenna, B and $\mathrm{C}$ - mandible, F - basale endite of mandible, E - sixth limb, F - toothrows and masticatory pad of coxa of mandible. 
Sixth limb (Fig. 15, A). The epipodite appendage has 3 groups of $4+4+5$ plumose setae. One long plumose seta is placed on the endopodite. The 1st segment of the exopodite is with 2 (one plumose) dorsal and 4 (all plumose) ventral setae. The 2 nd segment bears one ventral, and 3rd - one dorsal and one ventral setae. Two usual setae and one middle claw-seta are borne by the 4th segment. This claw seta and dorsodistal seta of the 1 st segment are about $80 \%$ of the exopodite in length (on the dorsal side). Height of the exopodite is approximately $35 \%$ its length.

Seventh limb (Fig. 14, F). It is prolonged and thick ( $25 \%$ of the length) and is about $30 \%$ of the longest seta in length. The short seta is $75 \%$ the length of the long one.

Copulatory appendage (Fig. 15, B-D). It is tapering towards the base and tip from the middle. The greatest height is at the middle. It is rounded at the tip and has 3 slightly developed muscles.

Caudal furca (Fig. 15, E). It has 8 pairs of slim claws and without odd bristle.

Redescription of adult female

Shell. The length is $1.2-1.4 \mathrm{~mm}$, as in male.

Frontal organ. It is does not extend beyond the down-curving distal segments of the 1st antenna and is about $80 \%$ of its dorsal side in length.

First antenna. As in male.

Second antenna. (Figs. 15, F and 16, A). The total length of the 2nd-9th segments of the exopodite is about $45 \%$ of the 1 st segment in length. The 1 st and 2 nd segments of the endopodite are covered with long hairs.

Mandible (Fig. 16, B-D, F). Basale is armed with 3 anterior, one anterolateral and 3 lateral setae. Main terminal claw - seta is $93-110 \%$ of the endopodite in length (on the dorsal side).

Maxilla and fifth limb. As in male.

Sixth limb (Fig. 16, E). The epipodial appendage has 3 groups of $4+4+4$ plumose setae. Middle claw-seta of the 4th segment is approximately $75 \%$ and distodorsal seta is $50 \%$ of the exopodite in length (on the dorsal side). Height of the exopodite is about $30 \%$ of the length.

Seventh limb and Caudal furca. As in male.

Comparison

The shell of A. maculata differs from that of A. versicula in having a large size, sculpture with waving shape cells, more asymmetrical another shape posterior margins on the left and right valves. Besides A. maculata has smaller frontal organ, longer 1st segment on the 1st antenna, and bears dorsal hairs on the 5th segment of this limb. It has longer exopodite and right clasper on the 2nd antenna, greater number of setae and teeth are situated on the basal segment of the mandible, less ventral setae on the 1st and greater number their 2nd segments of the 5th limb, greater number and length of the dorsal setae on the 1 st segment of the 6th limb, more prolonged 7th limb, more straighter and narrower penis, greater number of claws and no odd bristle on the furca.

\section{Distribution}

Kurile-Kamchatka Trench $\left(45^{\circ} 11 \mathrm{~N}-152^{\circ} 28 \mathrm{E}\right)$, depth $7280-9500 \mathrm{~m}$ (Chavtur, 1977a).

\section{Archiconchoecilla versicula (Deevey, 1978)}

Archiconchoecia versicula Deevey, 1978a: 46-50, figs. 2, 3; 1978 c: 106, 111, table 1; 1983: table 1; Angel, 1981: 558, fig. 194 (7, A - H); 1983: 553, 554, fig. 2; Chen and Lin, 1995: 42-43, fig. 48.

Distribution

Species is known from Pacific sector of the South Ocean $\left(37-44^{\circ} \mathrm{S}\right)$ at depth range of 1000 to 2000m (Deevey, 1978a; 1982; 1983). Also, A. versicula was found in the Caribbean Sea (Deeey, $1978 \mathrm{~b})$ and in the Northeastern Atlantic $\left(42^{\circ} \mathrm{N}, 17^{\circ} \mathrm{W}\right)$ at depth of $3300-3900 \mathrm{~m}$. 
Archiconchoecissa Chavtur gen. nov.

Archiconchoecia Müller, 1906: $43-44$ (part); 1912: 55 (part); Granata, Caporiacco, 1949: 14; Deevey, 1968: 22 (part); Poulsen, 1969: 14-15 (part).

Type-species - Archiconchoecissa pljusnini Chavtur n. sp.

Composition

This genus contains only 5 species: A. pljusnini n. sp., A. cucullata, A. aff. cucullata $1, A$. aff. cucullata 2, A. aff. pljusnini.

\section{Description}

Shell. Males range from 1.62 to $2.50 \mathrm{~mm}$ in length and females from 1.58 to $2.60 \mathrm{~mm}$. Valves are prolonged. Height of shells in male in and female approximately $25-40 \%$ and $35-45 \%$ of the length respectively (without posterodorsal spines); it is subequal at the anterior and posterior parts or slightly greater at the posterior part of shell (considerably greater in female A. cucullata on Angel, 1981, fig. 194-4a). Rostrum is strongly developed, long and wide; rostral incisure is absent. Dorsal margin is straight, ventral margin also, slightly convex or barely concave. Anterior margin is nearly straight or slightly rounded. Posterior margin is rounded or slightly rounded. Right valve has long posterodorsal spine. Ventral and posterior margins are serrated. Left asymmetrical gland is approximately at $65-90 \%$ of the way up the posterior margin and placed on developed tubercle; right gland is respectively at $55-65 \%$ and located on small tubercle. There are distinct primary reticular and secondary tile-like (with denticles) sculptures.

Frontal organ. It is straight or barely down-curved, long, narrow, considerably extended beyond the down-curving distal segments of the 1st antenna. Organ in male and female are respectively about $100-135 \%$ and $100-130 \%$ the length of the dorsal side on the 1 st antenna. Capitulum section is not separated (separated only in female A. cucullata on Angel, 1981, fig. 194-4c) and without hairs (with hairs only in male A. cucullata on Poulsen, 1969, fig. 4h).

First antenna. The limb is 5-jointed (6-jointed only in A. cucullata on Poulsen, 1969: 16, Fig. 36). The 2nd and 5th segments have each one long, slim seta and armed with hairs (seta of the 5th segment is shorter than 2nd one). Six long filaments are borne on the 5th and 6th segments equal in length, distally not dilating (or very slightly) and rounded or pointed at the tip. Dorsal margin of the limb is approximately $60-80 \%$ of the filaments in length. Height of antenna (on the 2nd segment) is about $15-20 \%$ of its length. All or some segments bear several hairs.

Second antenna. The exopodite is thin, shorter or about as long as the protopodite. The total length of the 2nd-9th segments of the exopodite is approximately $30-35 \%$ the length of the 1 st segment. Basal segment of the endopodite is with or without hairs, and without warty surface. The bristles "c", "d" (in A. aff. pljusnini) and also "e" (in A. pljusnini and A. cucullata 1) of the $2^{\text {nd }}$ segment in male are developed and have thick base or have only " $c$ " and " $d$ " undeveloped bristles ( $A$. aff. pljusnini). The middle part of the right clasper is not thick. The right and left claspers are tapering towards the tip or not, with a slight terminal thickening. The 5 filaments of the 2 nd segment of the endopodite are equal in length, distally somewhat widened and are slightly longer or about as long as the protopodite and exopodite.

Mandible. The epipodite is developed moderately, with or without bristle.

The exopodite is represented by 1-2 (medium length) midlong setae. The 1 st segment of the endopodite is armed with one dorsal and 4 ventral setae, the 2nd with 3 dorsal (one stout and 2 usual type) and 2 ventral setae. The 3 rd segment bears 7 setae, of which the 1 st and 3 rd dorsal setae are claw-like and 2nd longer than the 1st dorsal seta. The main terminal claw-seta is shorter than the endopodite (on the dorsal side). Basale is armed with 2 anterior and 2 lateral setae, and 1 anterolateral seta, and anterior row of the long hairs near the articulation. Basal endite has toothrow with 6 
distinctly separated terminal triangular teeth (plus one lateral in A. cucullata on Poulsen, 1969) and 2 short posterior bristles.

Maxilla. The basal segment of the endopodite bears 6 anterior and 5-6 posterior setae. The 2 nd segment has 1-2 claw-setae and 4-5 usual setae.

Fifth limb. The epipodial appendage has 3 groups of $6+4(5)+4(5)$ plumose setae (unknown for $A$. pljusnini $\mathrm{n}$. sp.). The 1st segment of the exopodite bears 7 ventral and 3 dorsal setae and the 2 nd with 3 ventral and one dorsal setae. The middle claw-seta of the 3 rd segment is about $60-80 \%$ the length of the exopodite (on the dorsal side) and about as long as its dorsal seta.

Sixth limb. The epipodite is armed with 3 groups of $5(6-7)+5(6)+5(6)$ plumose setae $(16-18$ total). One long plumose and one short nonplumose setae are placed on the endopodite. The 1 st segment of the exopodite bears 1-2 dorsal and 3-6 ventral setae, the 2 nd is with 3 ventral setae and the 3rd segment has one dorsal and one ventral setae. Two usual setae and one middle slim claw-seta are borne on the distal segment. The last claw-seta is about $60-70 \%$ the length of the exopodite (on the dorsal side). Height of the exopodite is $20-25 \%$ of the length.

Seventh limb. It is thin, prolonged (25-35\% of the length). The limb is $20-45 \%$ of its longest seta in length.

Copulatory appendage. It is slightly tapering towards the tip and fairly curved at the proximal parts. The greatest height is at the proximal part and about $25-35 \%$ of the length (from tip to dorsomedial indentation). The tip is wide, blunt and with small protuberance or without it.

Caudal furca. This limb has 7-8 pairs of claws and single unpaired bristle.

\section{Comparison}

New genus sharply differs from all the other genera in having larger and more prolonged rostrum, developed right posterodorsal spine, serrated ventral and posterior margins, and distinct primary reticular and secondary tile-like (with denticles) sculptures on the shell; additional dorsal seta is borne on the 4th segment of the 1 st antenna, and developed " $\mathrm{e}$ " bristle on the endopodite of the 2 nd antenna in male (bristles "c" -"e" with very thick base); greater number of setae are placed on the 1st segment of the endopodite of the maxilla, and also plumose setae on the 1st segment (on ventral side) of the exopodite of the 5 th limb and on the 2 nd segment of the exopodite of the 6 th limb.

This genus is somewhat close to Archiconchoecilla gen. nov., but has following differences (in addition to the above mentioned): larger shell; longer frontal organ pointed at the tip; shorter protopodite of the 2 nd antenna and seta (setae) on the endopodite of the mandible; greater number of posterior setae on the 1st segment of the endopodite of the 5th limb and on the endopodite of the 6th and 7 th limbs.

\section{Distribution}

Members of this genus were collected in deep-sea zone of the Atlantic, Indian and Southern Ocean and also West Pacific. The northernmost and southernmost latitudes are $60^{\circ} \mathrm{N}$ and $63^{\circ} \mathrm{S}$. The known depth range of the genus is $250(300)-5000 \mathrm{~m}$.

Key to Species of Genus Archiconchoecissa (without A. aff. cucullata 1)

1. Rostrum is down-curving and less than $15 \%$ of the shell in length, frontal organ is

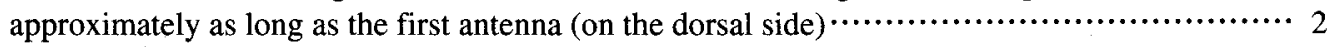
Rostrum is up-curving and over $20 \%$ of the shell in length, frontal organ is considerably longer than the 1 st antenna

2. Capitulum of frontal organ is fused with stem, terminal setae of 1 st antenna is twice as long as limb, seta " $\mathrm{e}$ " on 2nd endopodite antenna of male is developed …................ pljusnini n. sp. Capitulum of frontal organ is delimited from stem, terminal setae of 1st antenna is 1.5 length of

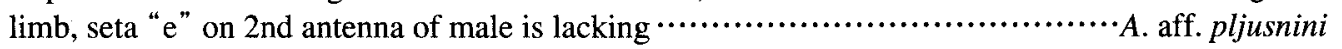


3. Size is more than $2.3 \mathrm{~mm}$, setae "c", "d" and "e" on 2 nd endopodite antenna are developed

Size is less than $2.1 \mathrm{~mm}$, only "c" and " $\mathrm{d}$ " minute setae are on 2 nd endopodite antenna

A. cucllata

A. aff. cucullata

\section{Archiconchoecissa pljusnini Chavtur sp. nov.}

(Figs. 17-20, 21, A, B)

Archyconchoecia cucullata: Chavtur, 1977a: 142, 158, fig. 8, table 6.

Archyconchoecia cuculata: Chavtur, 1977b: table 2; 1977c: table 2.

Archiconchoecia cucullata: Chavtur, 1991: 37.

Archiconchoecia sp. nov. Chavtur, 1992: table 2.

Material examined

Holotype. N1115 - adult male, length is $2.30 \mathrm{~mm}$, appendages are mounted on slide and valves preserved in alcohol. In collection of the Museum of Institute of Marine Biology, Vladivostok, Russia together (with paratypes). Type-locality. R/V “Vityaz" , station $7260,5^{\circ} 38^{\prime} 0-5^{\circ} 33^{\prime} 5 \mathrm{~N}$ and $130^{\circ} 48^{\prime}$ 3-48’ 2E, depth 5000-4079 m, 18 March 1975.

Paratypes. 1116 - adult female (length $2.20 \mathrm{~mm}$ ) from same sample as holotype; 1117 - adult female (length $2.25 \mathrm{~mm}$ ) station and date as of holotype, depth $4000-3495 \mathrm{~m}$.

Additional specimens - R/V "Vityaz" : juvenile, length $1.50 \mathrm{~mm}$, station and date as holotype, depth 4000-3495 m; adult female, length $2.30 \mathrm{~mm}$, station $7229,5^{\circ} 21^{\prime} 7-5^{\circ} 00^{\prime} 4 \mathrm{~N}, 124^{\circ} 21^{\prime} 7-124^{\circ} 04^{\prime}$ 4E, depth 3500-2994 m, 24 February 1975; juvenile, length $1.7 \mathrm{~mm}$, station $5628,43^{\circ} 54^{\prime} \mathrm{N}, 149^{\circ} 57^{\prime}$ E, depth 4100-3090 m, 31 August 1966.

All material including holotype and paratypes were caught by Plankton Bogorov-Rass's Net $\left(\mathrm{S}=1.0 \mathrm{~m}^{2}\right)$.

Etymology

The species is named after Dr. Vladimir N. Pljusnin.

Description of adult male

Shell. (Fig. 17, A-C). Length $2.3 \mathrm{~mm}$ (with rostrum and posterodorsal spine). Valves are prolonged. Height of shell about $40 \%$ of the length (without posterodorsal spines), and nearly equal at the anterior and posterior parts. Rostrum is strongly developed, long, wide, down-curving and about $15 \%$ of the shell in length (without posterodorsal spines). Rostral incisure is absent. Dorsal margin is straight and ventral margin is slightly concave. Posterior and anterior margins are slightly rounded. Posterior margins of the left and right valves are asymmetrical: right valve is with long and pointed posterodorsal spine and left without it. Ventral and posterior margins are serrated. Left asymmetrical gland is located approximately at $90 \%$ of the way up the posterior margin and placed on developed tubercle, right gland is at $60 \%$ and on small tubercle respectively. There are distinct primary reticular and secondary tile-like (with denticles) sculpturing.

Frontal organ (Fig. 17, D, E). It is straight, long, narrow considerably extended beyond the curved distal segments of the 1st antenna, and is about as long as the dorsal side of the 1st antenna. Capitulum section is down-curved distally, unseparated, pointed at the tip, slightly thicker than stem and without hairs and spinules.

First antenna. (Fig. 17, D, E). The limb is 5-jointed, and with one dorsal seta on each of the 2nd and 6 th segments. These setae are long, slim and armed with hairs. Long filaments are borne on the 5 th segment equal in length, distally widened and pointed at the tip. Dorsal margin of the limb is approximately $80 \%$ of the filaments in length. Height of antenna (on the 2 nd segment) is about 15 $20 \%$ of the length. Some hairs are placed laterally on the 2 nd, 3 rd and 5 th segments. The first 
segment has several dark pigment spots.

Second antenna (Fig. 17, F-J). The exopodite is thin, barely shorter than the protopodite. The total length of the 2nd-9th of the exopodite is $30-35 \%$ of the 1 st segment in length. Basal segment of the endopodite is armed with tiny hairs and without warty surface. Its bristles " $a$ " and " $b$ " are long, thick in the base and with hairs. The bristles " $c$ ", $\mathrm{d}$ " and " $\mathrm{e}$ " placed on the 2 nd segment are very thick in the base. The right clasper is curved, with short base and terminal thickening; the base is slightly thinner than the middle part. The left is clasper curved, without terminal thickening and shorter than the right one. The 5 filaments placed on the 2 nd segment are about equal in length, distally somewhat widened, slightly pointed at the tip, barely shorter than the protopodite, and about as long as the exopodite.

Mandible (Fig. 18, A-D). The epipodite is developed moderately and without bristles. The exopodite is represented by 2 midlong setae. The 1 st segment of the endopodite is with untuberous dorsal margin and armed with one dorsal and 4 long ventral setae, the 2nd segment has 3 dorsal (one stout and 2 usual type) and 2 ventral setae. The distal segment bears 7 setae, of which the 1 st and 3 rd dorsal setae are claw-like and 2nd longer than the 1st dorsal seta. The main terminal claw-seta is approximately $75 \%$ of the endopodite in length (on the dorsal side). Basale is armed with 2 anterior and 2 lateral setae, and one anterolateral seta, and anterior row of the long hairs near the articulation. Basal endite has toothrow with 6 distinctly separated triangular teeth and 2 short posterior proximal bristles. Coxale endite carries out 3 closely set toothrows. Numerous spines (or short filaments) and hairs are placed on the flat masticatory pad.

Maxilla (Fig. 18, E, F). The basal segment has 6 (all plumose) anterior and 5 (4 plumose) posterior setae. The distal segment is armed with 2 claw-setae and 4 usual setae.

Fifth limb (Fig. 19, A). The epipodite is torn. The 1st segment of the exopodite bears 7 (4 plumose) ventral and 3 ( 2 plumose) dorsal setae, of which distodorsal seta is approximately as long as the exopodite (on the dorsal side). The 2 nd segment has 3 ventral and one dorsal setae, and the last seta is about $40 \%$ and middle claw-seta of the 3 rd segment is $60 \%$ of the exopodite in length. Terminal dorsal and middle claw-setae are subequal in length. Hairs are placed on the ventral side of the 1 st and 2 nd segments of the exopodite.

Sixth limb (Fig. 19, B, C). The epipodial appendage has 3 groups of $5+5+6$ plumose setae. One long and one short plumose setae are placed on the endopodite. The 1 st segment of the exopodite bears 2 dorsal and 3 ventral plumose setae. The 2 nd segment is with 3 ventral and the 3 rd has one dorsal and one ventral setae. Two usual setae and one middle slim claw-seta are borne on the 4th segment. This claw-seta is $65-70 \%$ of the exopodite in length (on the dorsal side). Height of the exopodite is $20-25 \%$ of the length.

Seventh limb. It is thin and prolonged (35\% of the length). The longest seta is about twice the length of the short seta and 5 times as long as the limb.

Copulatory appendage (Fig. 18, H). It is tapering towards the tip and obviously curved at the proximal part. The greatest height is at the base and is about $25 \%$ of the length (from tip to dorsomedial indentation). The tip is wide, blunt and bears a small protuberance. Penis is with a few muscles.

Caudal furca. (Fig. 18, G). This limb has 7 pairs of slim claws and single unpaired bristle.

Description of adult female. Shell (Fig. 20, A, B). Length is 2.2-2.3 mm (with rostrum and posterodorsal spines). Left and right asymmetrical glands are at $85-90$ and $60-65 \%$ of the way up the posterior margin respectively.

Frontal organ (Fig. 19, D, E) and First antenna. As in male.

Second antenna (Fig. 20, C). Bristles " $a$ " and " $b$ " placed on the 1st segment are long, usual in the base and covered with short hairs. The 2 nd segment is without " $c$ "- " $\mathrm{e}$ " bristles.

Mandible (Figs. 19, F and 21, A, B). Main terminal claw-seta is about $80 \%$ of the endopodite in length (on the dorsal side). 


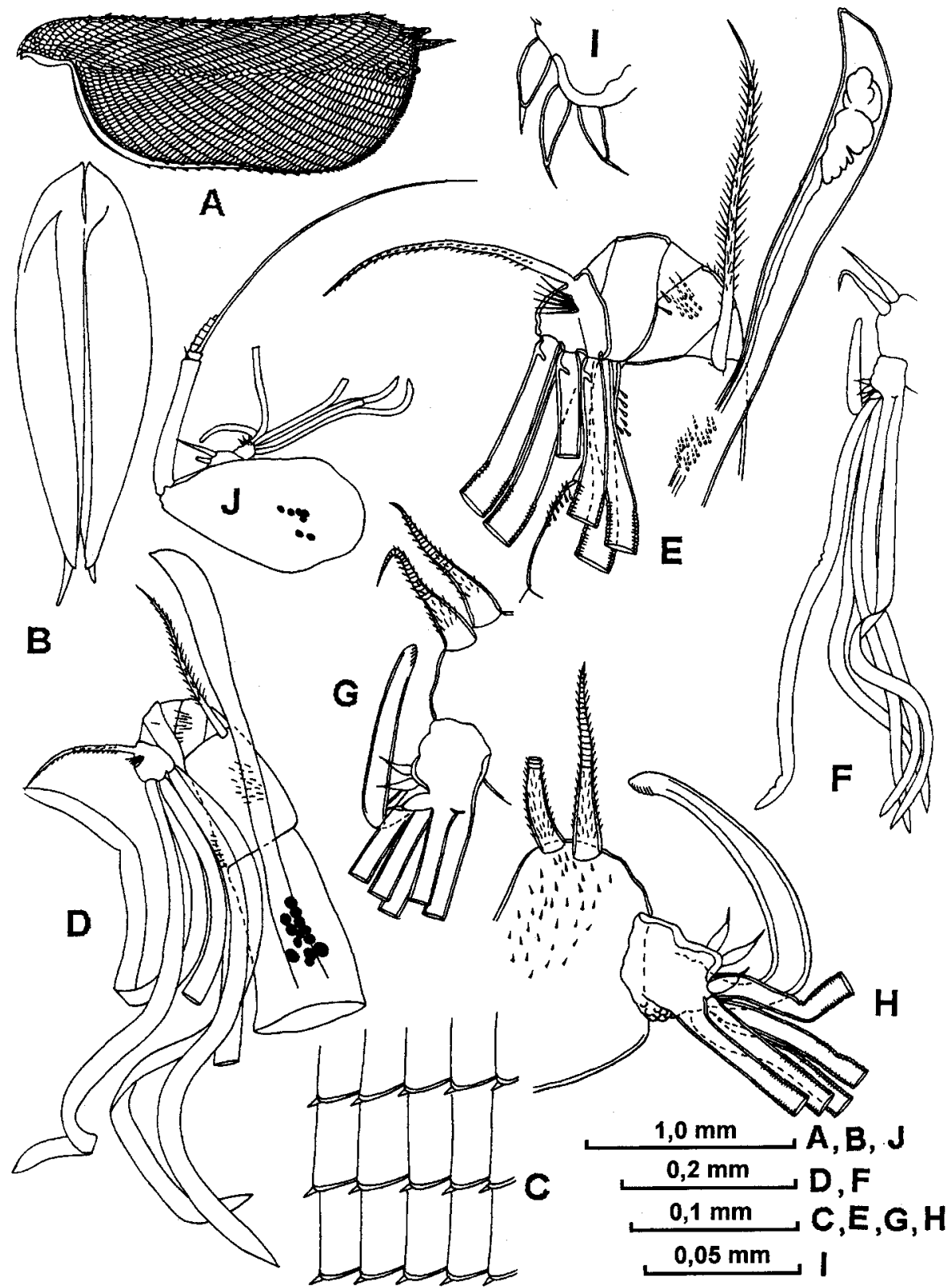

Fig. 17 Archiconchoecissa pljusnini sp. nov. (male: 1115) A - lateral view of left valve of shell, B ventral view of shell, $C$ - sculpture of shell, D and E - frontal organ and lst antenna, F and G - left endopodite of 2 nd antenna, $\mathrm{H}$ - right endopodite of 2 nd antenna, I - bristles " $\mathrm{c}$ ", " $\mathrm{d}$ " and " $\mathrm{e}$ " of endopodite of $2 \mathrm{nd}$ antenna, $\mathrm{J}$ - 2nd antenna. 


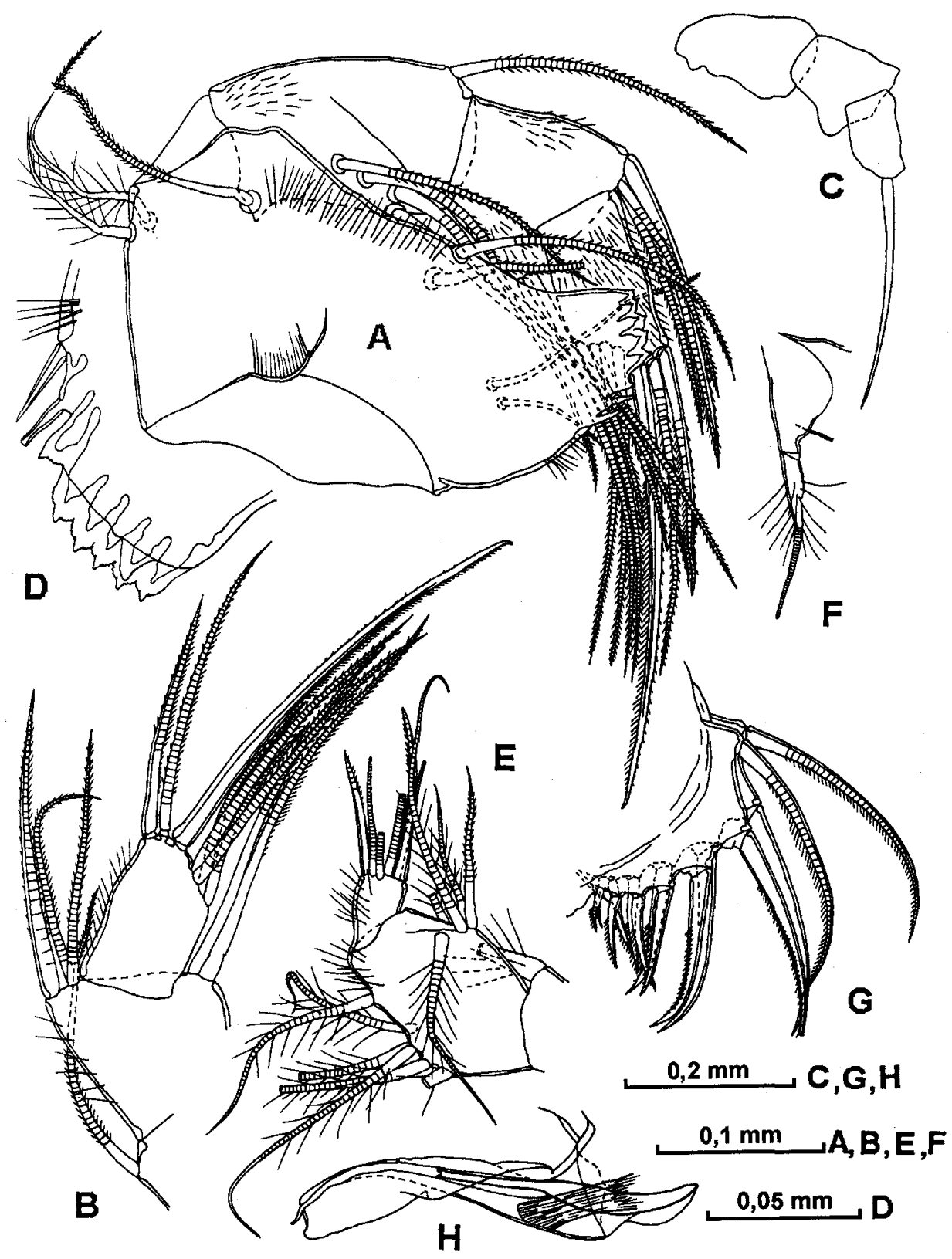

Fig. 18 Archiconchoecissa pljusnini sp. nov. (male: 1115) A - mandible, B and C - endopodite of mandible, D - basal endite of mandible, E - maxilla, F - seta of basale segment of maxilla, G furca, $\mathrm{H}$ - penis. 


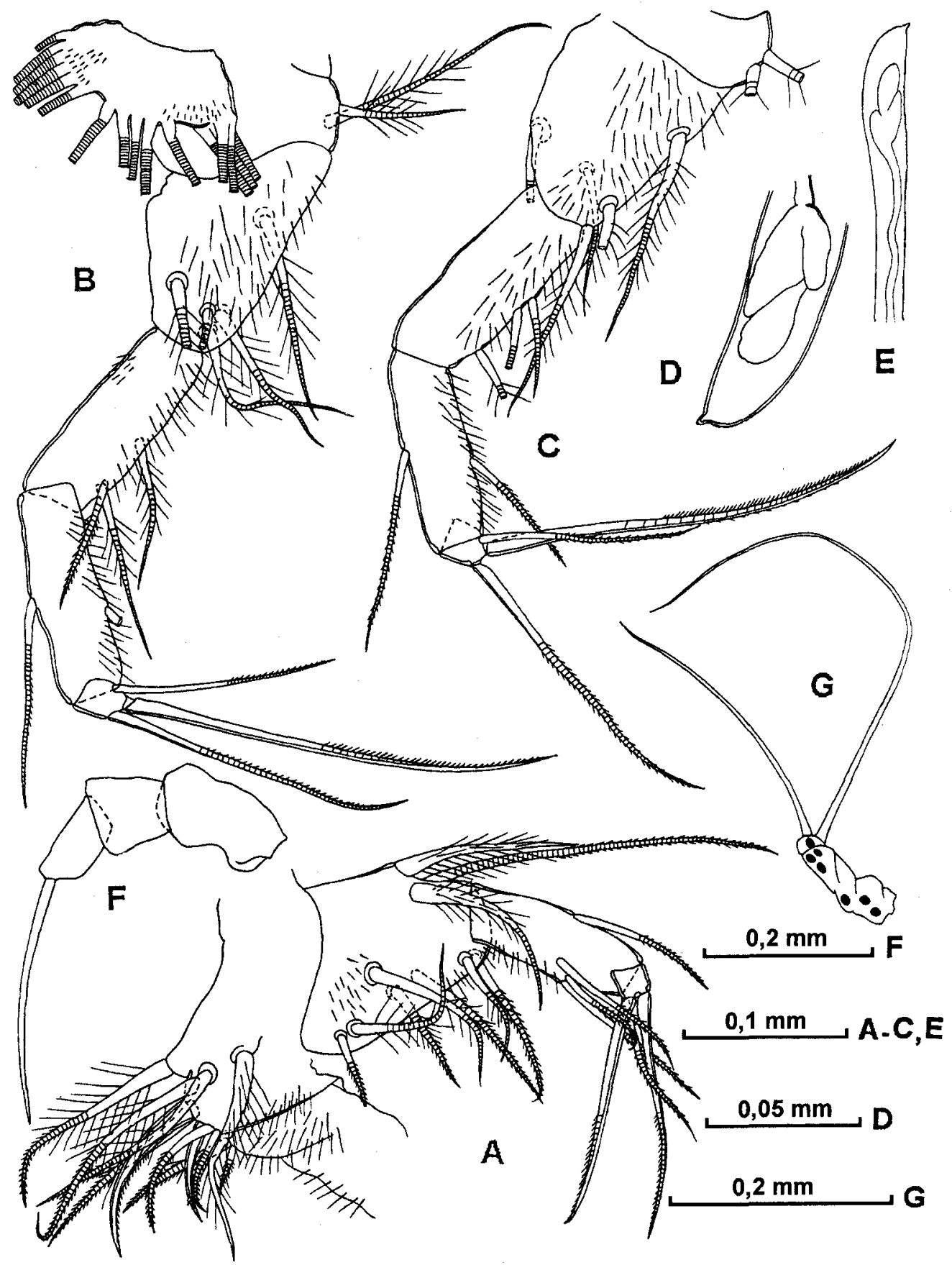

Fig. 19 Archiconchoecissa pljusnini sp. nov. (male: 1116 - A-C, female: 1116 - D-F, female: '1117 - G ) A - fifth maxilla, B and C - sixth limb, D and E - distal part of frontal organ, F - endopodite of mandible, $\mathrm{G}$ - seventh limb. 


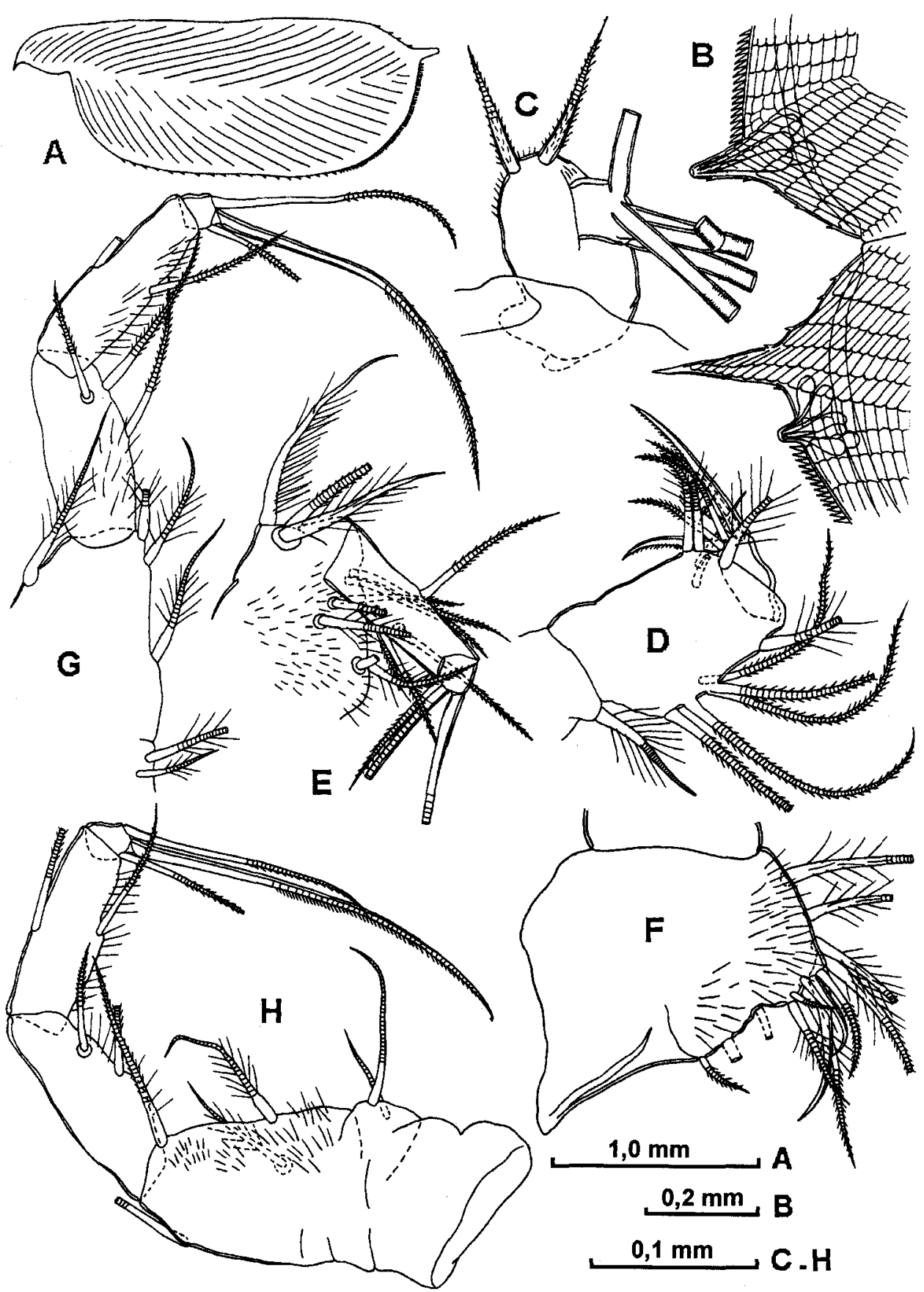

Fig. 20 Archiconchoecissa pljusnini sp. nov. (female: 1116 - A, B, G, H; 1117 - C-F) A - lateral view of left valve of shell, B - posterodorsal margin of the shell, $\mathrm{C}$ - endopodite of 2 nd antenna, D maxilla, E and F - distaland proximal parts of fifth limb, $\mathrm{G}$ and $\mathrm{H}$ - sixth limb. 
Maxilla (Fig. 20, D). The 1st segment of the endopodite has 6 (one plumose) anterior and 5 (2 plumose) posterior setae.

Fifth limb (Fig. 20, E, F). As in male.

Sixth limb (Fig. 20, G, H). The Ist segment of the exopodite bears one dorsal and 3 ventral plumose setae. Middle terminal claw-seta is about $60 \%$ of the exopodite in length (on the dorsal side).

Seventh limb (Fig. 19,G) and Caudal furca. As in male.

\section{Comparison}

The new species differs from A. cucullata in following respects: rostrum is shorter and downcurving; frontal organ is also shorter; exopodite of the mandible is with 2 setae; 1 st segment of the sixth limb bears lesser number of setae; furca has only 7 pairs of the claws and single unpaired bristle. Distribution

This species was collected in the West Pacific between latitudes of $43^{\circ} \mathrm{N}$ to $5^{\circ} \mathrm{S}$ (Kurile Kamchatka Trench, the Banda and Sulawesi Seas) at the depth range 3000-5000 m.

\section{Archiconchoecissa aff. plusnini}

Archiconchoecia aff. cucullata: Angel, 1993: 74, Fig. 24.

\section{Remarks}

This is new abyssopelagic species requires formal description (Angel, 1993). It is closely related to A. pljusnini, but differs in some respects (in brackest for A. plusnini): the capitulum of the frontal organ in both sexes is delimited from the stem by suture (fused), terminal setae of the 1st antenna in both sexes are about one and half (twice as long as) the length of the limb, the "e"-bristle placed on the 2nd endopodite antenna in male is lacking (it is developed and have very thick base).

\section{Distribution.}

It occurs at $20^{\circ}-49^{\circ} \mathrm{N}$ in deep water in the Atlantic (Angel, 1993).
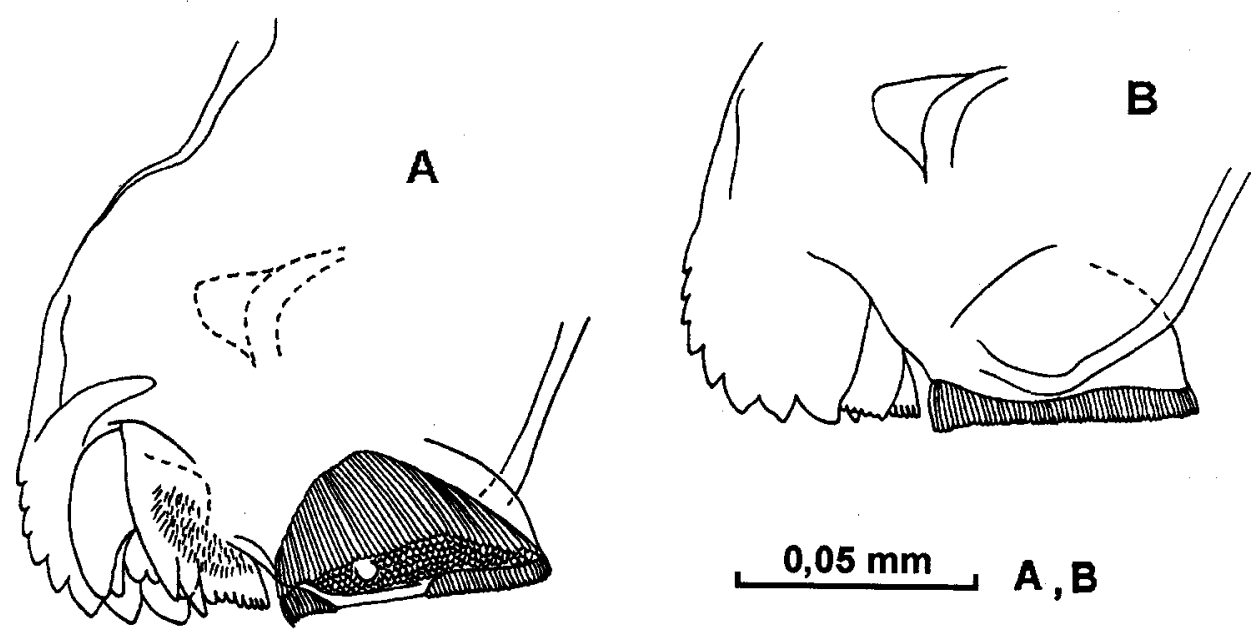

Fig. 21 Archiconchoecissa pljusnini sp. nov. (female: 1117) A and B - toothrows and masticatory pad of coxa of mandible. 


\section{Archiconchoecissa cucullata (Brady, 1902)}

Conchoecissa cucullata Brady, 1902: 191, 199, pl. 24, figs. 1-8: 1903: 338, 339; Cleve, 1905: 131.

Archiconchoecia cucullata: Müller, 1906: 44, Taf. 7, Fig. 7-12, 18; 1908: 63; 1912: 56; Fowler, 1909: 256, 279, 296; Skogsberg, 1931: 4; Granata, Caporiacco, 949: 18; Leveau, 1967: 67; Deevey, 1968: 23-25, fig. 5; 1971: 231; 1974: 355, 358; 1978a: 45, 46; 1978b: 54, 59; 1982: 134, 136; 1983: 411; Deevey, Brooks, 1980: 59, 61-62, tab 2, 3; Hillman, 1969: 30; Poulsen, 1969: 15-21, figs. 3-5; Angel, 1969a: 519, 540; 1969b: 78, 79; 1979: 79-81, fig. 71; 1981: 555, fig. 194 (4A-H); 1983: 552, 554; 1984: 321; 1993: 70, Figs. 22; Angel and Fasham, 1975: 718, 719, 720, 721, 725, 728, 730, 738; Angel et al., 1982: 300, 307; 1993: 70, Fig. 22; Fasham et al., 1974: 98; Alcaraz, 1977: 3, 6 10; Hanai et al., 1980: 53; Drapun, 1981: 75; 1983: 34; 1988: 49; Chen et al., 1983: 92-93, fig. 10; Ellis, 1985: 929, 942; Yin, 1991: 77; Chen and Lin, 1995: 41, fig. 46.

Not Archyconchoecia cucullata: Chavtur, 1977a: 142, 158, fig. 8, tab. 6.

Not Archyconchoecia cuculata: Chavtur, 1977b: table. 2; 1977c:.table. 2.

Not Archiconchoecia cucullata: Chavtur,1991: 37.

Material examined - $\mathrm{R} / \mathrm{V}$ "Lomonosov", 1959: adult female (length $2.2 \mathrm{~mm}$ ) and juvenile $(1.5 \mathrm{~mm}$ ), station $466,22^{\circ} 19^{\prime} \mathrm{N}$ and $61^{\circ} 02^{\prime} \mathrm{W}$, depth $2600-0 \mathrm{~m}, 2$ October: adult female (1.8 mm), station 505 , $31^{\circ} 23^{\prime} \mathrm{N}$ and $16^{\circ} 48^{\circ} \mathrm{W}$, depth $1618-0 \mathrm{~m}, 31$ October; adult female $(1.8 \mathrm{~mm})$, station $508,34^{\circ} 53^{\prime} \mathrm{N}$ $14^{\circ} 52^{\prime}$ W, depth 1620-0 m, 2 Nov.ember (collected by Plankton Conic Net, $\mathrm{S}=1.0 \mathrm{~m}^{2}$ ).

Distribution

This species inhabits Atlantic Ocean in latitudes range of $60^{\circ} \mathrm{N}$ to its south boundary (NE Atlantic - Brady, 1902; 1903; Müller, 1906; 1908; 1912; Folwler, 1909; Skogsberg, 1931; Granata, Caporiacco, 1949; Poulsen, 1969; Angel, 1969a; 1969b; 1979; 1981; 1983; 1984; Angel, Fashim, 1975; Angel et al., 1982; Fasham et al., 1974; Alcaraz, 1977; Ellis, 1985. NW Atlantic - Skogsberg, 1931; Granata, Caporiacco, 1949; Deevey, 1968; 1971; 1978b; 1982; Deevey, Brooks, 1980; Poulsen, 1969; Angel, 1979; 1981. S Atlantic - Müller, 1908; Deevey, 1974; Angel, 1981; Drapun, 1981; 1983; 1988), Indian Ocean between $7^{\circ} \mathrm{N}$ and its south boundary (Cleve, 1905; Müller, 1906; 1908; Leveau, 1967; Poulsen, 1969; Hanai et al., 1980), Pacific Ocean between Paraselsky Islands (South China Sea) and $5^{\circ}$ S (NW Pacific-Poulsen, 1969; Hanai et al., 1980; Chen et al., 1983; Chen and Lin, 1995. S PacificPoulsen, 1969) and South Ocean from its north boundary to $63^{\circ} \mathrm{S}$ (Atlantic sector - Müller, 1906; Hillman, 1969; Poulsen, 1969; Deevey, 1974. Indian sector - Müller, 1908; Hillman, 1969; Poulsen, 1969; Deevey, 1982. Pacific sector - Hillman, 1969; Deevey, 1978a; 1982, 1983). A. cucullata is known in the depth range of $250-300$ to $3000-4000 \mathrm{~m}$, but usually bellow $500 \mathrm{~m}$. Most numerous were caught in the level 500-1000 m (Angel, 1979) and 2000-2500 m (Poulsen, 1969).

\section{Archiconchoecissa aff. cucullata 1}

Archiconchoecia aff. cucullata Angel, 1983: 553 (tab.1).

Remark

Angel's publication contains no morphological information for this species.

Distribution

Collected only in the region $42^{\circ} \mathrm{N}-17^{\circ} \mathrm{W}$ from levels $3500-3700$ and $3700-3900 \mathrm{~m}$.

\section{Archiconchoecissa aff. cucullata 2}

Archiconchoecissa aff. cucullata: Angel, 1993: 72 (part), Fig. 23 
Remarks

This is closely related to A. cucullata, but differs in following: the carapace is noticeably shorter, the endopodite of the $2^{\text {nd }}$ antenna is bare and armed with (in male) minute " $c$ " and " $d$ " bristles (" $e$ "bristle is lacking).

Distribution

This is more abundant than A. cucullata and sometimes sub-dominant at deep mesopelagic depths at lower latitudes (Angel, 1993: location is not reported).

\section{Archiconchoecemma Chavtur gen. nov.}

Type-species - Archiconchoecia simula Deevey, 1982

Composition

This genus contains only 2 species: A. simula (Deevey, 1982) and A. orientalis (Chavtur, 1987).

\section{Description}

Shell. Males range from 1.3 to $1.4 \mathrm{~mm}$ in length, and female from 1.4 to $1.44 \mathrm{~mm}$. Valves are slightly prolonged. Height of shell in male and female is approximately 55 and $60 \%$ of the length respectively. Greatest height is at the posterior part. Rostrum is slightly developed, and rostral incisure is absent. Dorsal and ventral margins are straight or nearly straight. Anterior and posterior margins are evenly rounded and symmetrical. Posterior margin is without tubercles and points. Left and right asymmetrical glands are about $85-90$ and $65-70 \%$ of the way up the posterior margin respectively. No sculpturing is noted on the shell or there is slight indication of sculpturing, as lines approximately paralleling the dorsal margin and near anterior and posterior margins.

Frontal organ. It is slightly down-curved, short, narrow and barely extended beyond the downcurving distal segments of the 1st antenna. Organ in male and female is approximately $75-95 \%$ and $85-90 \%$ the length of the dorsal side of the 1st antenna, respectively. Capitulum section is downcurved distally, unseparated, pointed at the tip, and with tiny hairs at its posterior part.

First antenna. The limb is 6 -jointed, with one dorsal seta placed on the 2 nd segment. The seta is short, slim and armed with hairs. The 5th and 6th segments are with 6 long filaments unequal in length, distally not widened and rounded or pointed at the tip. Dorsal margin of the limb is $75-80 \%$ of the filaments in length. Height of antenna (on the 2nd segment) is $15-20 \%$ of the length. Hairs on the 4th segment are absent.

Second antenna (male of $A$. orientalis unknown). The exopodite is thin and nearly as long as the protopodite. The total length of the 2nd-9th segments of the exopodite is approximately $30-35 \%$ of the 1 st segment in length. Basal segment of endopodite is armed with spinules around the bases of the bristles. The 2 nd segment is covered with long hairs in female and has short bristles " $c$ " and " $d$ " in male. The right clasper is hook-like, sharply curved and slightly widened in the middle. The left clasper is quite small and thumb-like. Claspers do not taper distally. The 5 filaments placed on the 2nd segment are distally somewhat widened towards the tip and are unequal in length ( 2 proximal filaments are longer than the other 3).

Mandible. The epipodite is developed and with short bristle on the thick base (unknown for $A$. simula). The exopodite is represented by 2 long setae ( 3 in female of $A$. simula). The 1 st segment of the endopodite has one dorsal and 4 ventral setae and the 2 nd segment has 3 dorsal and 2 ventral setae. The 3rd segment bears 7 setae, of which 1 st and 3rd (3rd and 4th in A. orientalis) dorsal setae are claw-like, 2nd seta is very slight and considerably shorter than the 1 st dorsal seta, and main claw-seta is longer than the endopodite (on the dorsal side) in female and shorter in male. Basale is armed with 3-4 anterior and 2 lateral setae and 1 anterolateral seta near the articulation. Basal endite has toothrow with 6 distinctly separated triangular teeth (plus one lateral tooth in A. orientalis). 
Maxilla. The basal segment of the endopodite bears 6 anterior and 4-6 posterior setae. The distal segment is armed with 2 claw-setae and 3 usual setae.

Fifth limb. The epipodite has 3 groups of $4+4+4(5)$ plumose setae. The 1 st segment of the exopodite bears 7 ventral and 3 dorsal setae and 2 nd segment has 2 ventral and one dorsal setae. The middle claw-seta of the 3 rd segment is about $65-70 \%$ of the exopodite in length (on the dorsal side) is slightly longer than its dorsal seta.

Sixth limb. The epipodial appendage has groups of $5+5+5(6)$ plumose setae. One long plumose seta is placed on the endopodite. The 1 st segment of the exopodite bears 2 dorsal and 5 ventral setae, the 2 nd segment has only one ventral and 3 rd - one dorsal and one ventral setae. Two usual setae and one middle slim claw-seta are located on the distal segment. This claw-seta is approximately $80 \%$ of the exopodite in length (on the dorsal side). Height of the exopodite is $30-45 \%$ of the length.

Seventh limb. It is very thin (torn in A. orientalis), prolonged (about $10 \%$ of the length). The limb is $30 \%$ the length of the longest seta .

Copulatory appendage (known only in A. simula). It is tapering towards the base and the tip from the middle, and is rounded at the tip. The greatest height is at the middle and approximately $40 \%$ of the length (from tip to dorsomedial indentation).

Caudal furca. This limb has 7-8 pairs of claws and single odd bristle.

\section{Comparison}

New genus differs from all the other genera by greater number of long setae placed on the exopodite of the mandible, and very short slight seta on the 3rd segment of its endopodite.

This genus is close to Archiconchoecia Müller, 1894 in shape, sculpture, and location of the asymmetrical glands of the shell. But it is separated (in addition to the above said) by some larger and more prolonged shell without dorsomedial indentation. Besides, its frontal organ is pointed at the tip, protopodite and exopodite of the 2 nd antenna are equal in length, right clasper is of usual type (without thickening in the middle), the 1st segment on the exopodite of the 6th limb and furca are armed with more of setae and claws, respectively.

\section{Distribution}

Members of the new genus have been taken in a deep-sea zone of the Southern Ocean, North Pacific and North Atlantic. The northernmost and southernmost latitudes are $37^{\circ} \mathrm{N}-72^{\circ} \mathrm{S}$. The known depth range of the genus is $1015-4000 \mathrm{~m}$.

Key to Species of Genus Archiconchoecemma (Adult male and female)

1. Shell has linear sculpture, $1 \mathrm{st}$ segment of endopodite of maxilla bears 6 posterior setae, furca has 7 pairs of claws …............................................ orientalis (Chavtur) Shell without noted sculpture, 1 st segment of endopodite of maxilla bears 4 posterior setae, furca has 8 pairs of claws A. similia (Deevey)

\section{Archiconchoecemma orientalis (Chavtur, 1987)}

(Figs. 22-24)

Archyconchoecia orientalis Chavtur, 1987: 943-945, fig.1, 1-8; 3, 1-3; 1991: 43.

Archiconchoecia orientalis Chavtur, 1992: table 2 (list).

Material examined

Holotype. N1118 - (N18815 - obsolete number) - adult female, length $1.4 \mathrm{~mm}$, appendages are mounted on slide and valves conserved in alcohol. In collection of the Museum of Institute of Marine Biology, Vladivostok, Russia. Type-locality - R/V “Vityaz”, station 6151, 37³8' 6-38' 48N, $143^{\circ} 51^{\text {' }}$ 
5-52 6 E, depth 2500-2000 m, 29 June 1969 (Plankton Bogorov-Rass's Net, S=0.5 m²).

Redescription of adult female.

Shell (Fig.22, A, B). Length $1.4 \mathrm{~mm}$. Valves are slightly prolonged. Height of shell approximately is $60 \%$ of the length. Highest at the posterior part. Rostrum very small, and rostral incisure absent. Dorsal and ventral margins are nearly straight and barely concave at the medial part. Anterior and posterior margins are evenly rounded. Left and right asymmetrical glands are about 85 $90 \%$ and $65-70 \%$, of the way up the posterior margin, respectively. Shell has slight indication of sculpturing, as lines, approximately paralleling the dorsal margin and near anterior and posterior margins.

Frontal organ (Fig. 22, C). It is curved, short, subequal thickness throughout, barely extending beyond the down-curving distal segments of the 1st antenna and about $75 \%$ of the 1st antenna in length (of the dorsal side). Capitulum section is down-curved, unseparated, pointed at the tip and has tiny hairs at its posterior part.

First antenna. (Fig. 22, A). The limb is 6-jointed. Dorsal seta of the 2nd segment is short, slim and armed with hairs. Long filaments on the 5th and 6th segments are unequal in length: 2 most distal filaments being somewhat shorter than others. One of proximal filaments is slightly widened in distal and pointed at the tip, and the other 5 filaments are unwidened and rounded respectively. Dorsal margin of the limb is about $70 \%$ of the filaments in length. Height of antenna (on the 2nd segment) is $20 \%$ less $(17 \%)$ than the length. The 1 st and 2 nd segments are covered with lateral hairs. The 1 st segment has some dark pigment spots.

Second antenna (Fig. 22, D). The exopodite is thin and about as long as the protopodite. The total length of the 2 nd-9th segments is about $30 \%$ of the 1 st segment in length. Basal segment of the endopodite is armed with long hairs, its bristles " $a$ " and " $b$ " are short. The 2 nd segment has long hairs and without " $\mathrm{c}$ " - $\mathrm{e}$ " bristles. The 5 filaments are slightly widened distally and unequal in length (2 proximal filaments are longer than the other 3 ).

Mandible (Figs. 22, E-G, 23, A, E, F and 24, A). The epipodite is developed and has one short bristle placed on the thick base. The exopodite is represented by 2 long setae are armed with long proximal and short distal hairs. The 1st segment of the endopodite has untuberous dorsal margin and covered with one dorsal and 4 ventral setae; the 2nd segment has 3 dorsal (1st dorsal is claw-like) and 2 ventral setae. The 3 rd segment bears 7 distal setae, of which $1 \mathrm{st}$, 3rd and 4th setae from the dorsal side are claw-like and 2nd seta is about $1 / 3$ of the 1st seta in length. Basale is armed with 3-4 anterior and 2 lateral setae and one anterolateral seta near the articulation. Basal endite has toothrow of 6 distinctly separated terminal and one lateral triangular teeth and 2 short posterior bristles. Coxal endite is armed with 3 closely set toothrows and with tiny hairs. The flat masticatory pad is covered with numerous varisized filaments.

Maxilla (Fig. 23, B). The basal segment of the endopodite bears 6 plumose anterior and 6 (2 plumose) posterior setae. The 2nd segment has 2 claw-setae and 3 usual setae.

Fifth limb (Fig. 23, C). The epipodite has 3 groups of $4+4+5$ plumose setae. The 1 st segment of the exopodite bears 7 ventral and 3 dorsal setae, of which distodorsal seta is about $90 \%$ the length of the exopodite (on the dorsal side). The 2 nd segment has 2 ventral and one dorsal setae, the last seta is $55 \%$ and middle claw-seta of the 3 rd segment is about $70 \%$ of the exopodite in length, respectively. This claw-seta is barely longer than the dorsal seta its segment. Long hairs are placed only on the ventral surface of the 1 st segment.

Sixth limb (Fig. 23, D). The epipodial appendage is covered with 15 plumose setae. Only one long plumose seta is located on the endopodite. The 1st segment of the exopodite has 5 ventral and 2 dorsal setae, the 2 nd segment has one ventral and the 3 rd has one ventral and one dorsal setae. Two usual setae and one midlong claw-seta are placed on the distal segment. This claw-seta is about $90 \%$ and distodorsal seta of the 1 st segment is approximately $40 \%$ the length of the exopodite (on the dorsal 

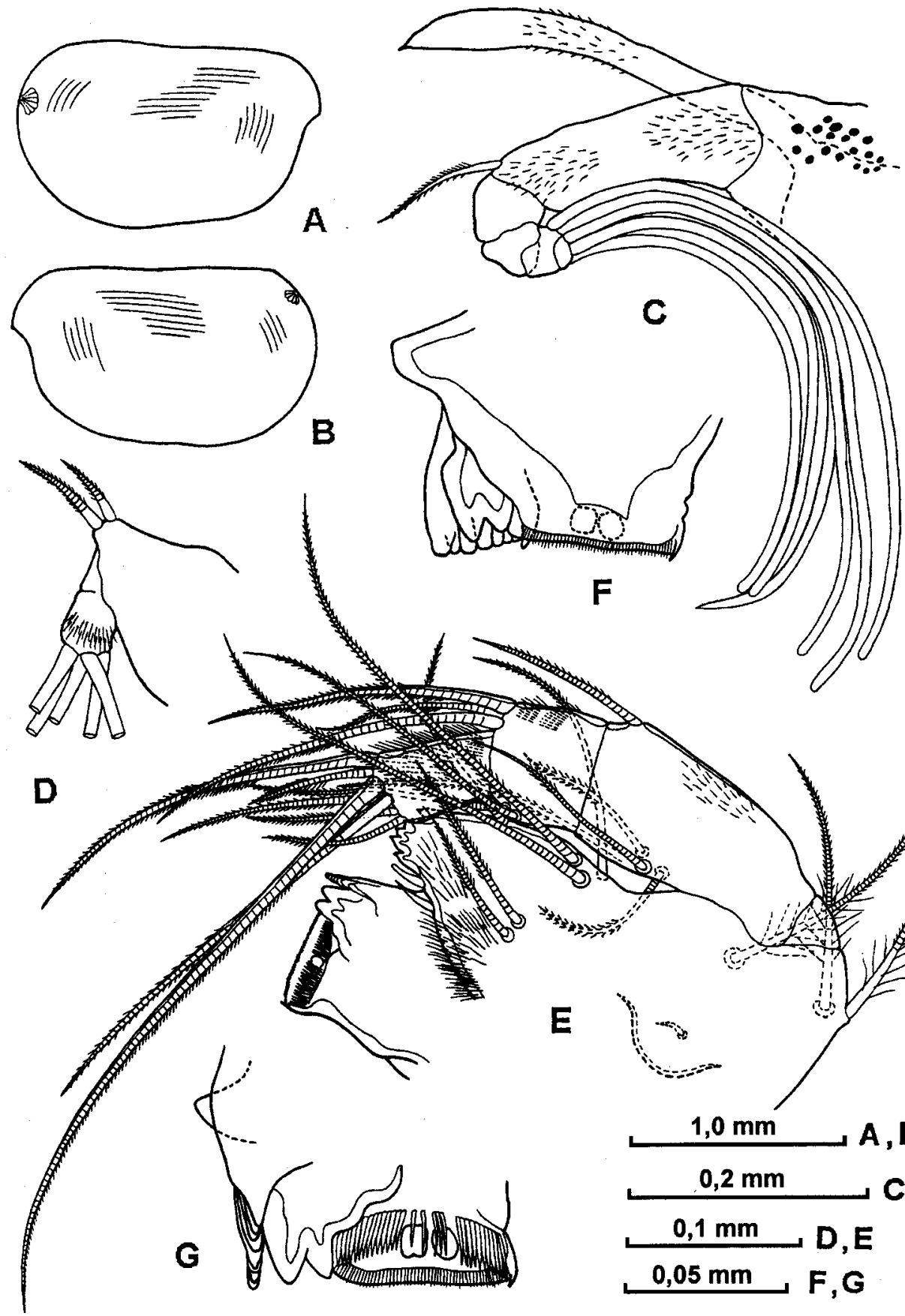

C

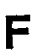

F
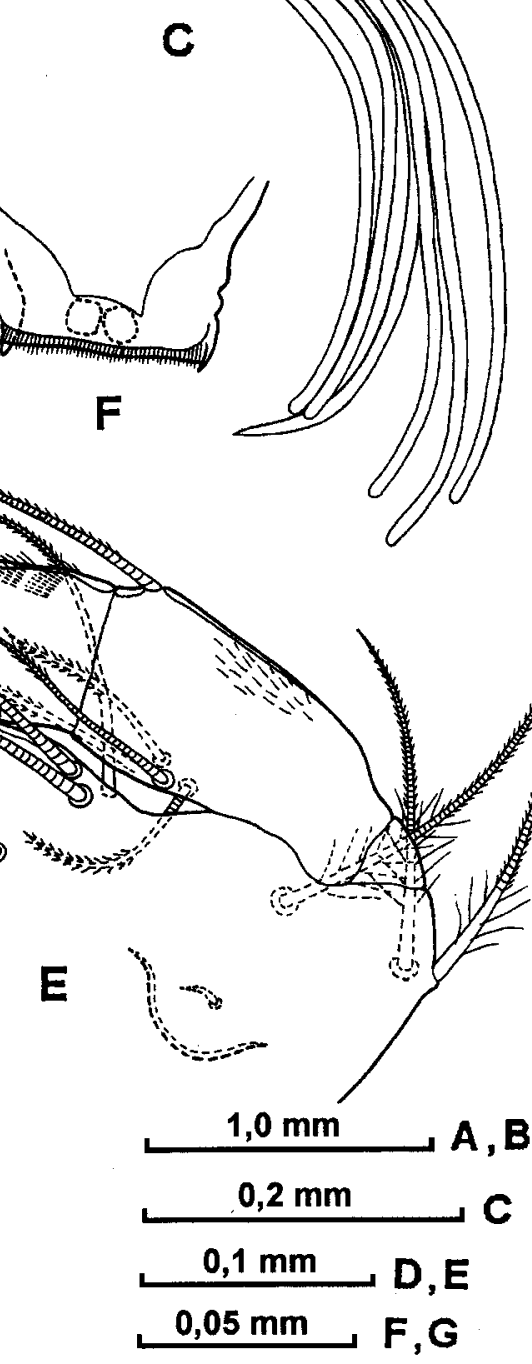

Fig. 22 Archiconchoecemma orientalis (female: 18815) A, B - lateral view of right and left of shell, C frontal organ and 1st antenna, D - endopodite of 2 nd antenna, E - mandible, F and G - toothrows and masticatory pad of coxa of mandible. 


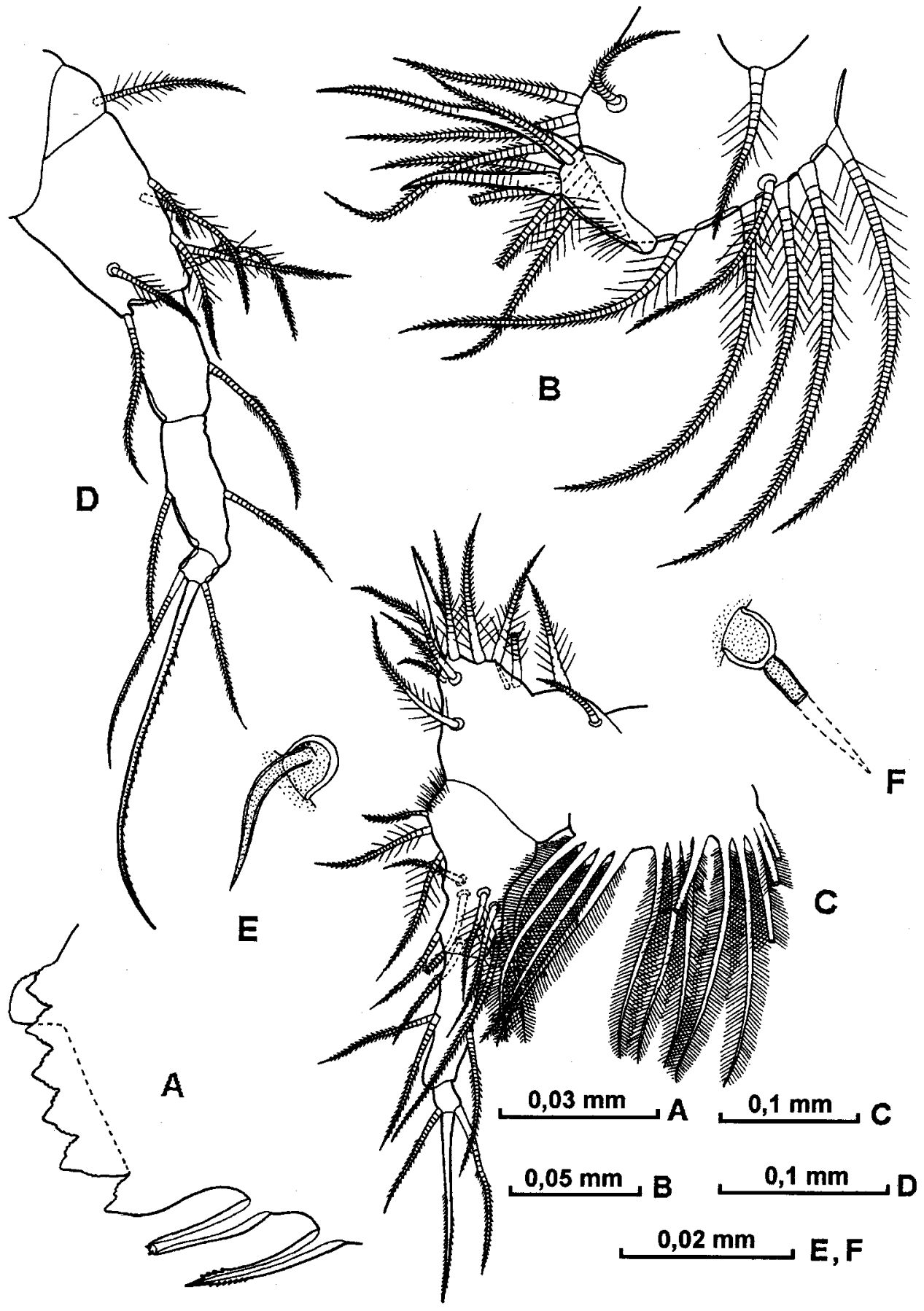

Fig. 23 Archiconchoecemma orientalis (female: 1118) A - basal endite of mandible, B - maxilla, C - fifth limb, D - sixth limb, E and F - epipodial bristle of mandible. 
side). Height of the exopodite is $30-35 \%$ of the length.

Seventh limb. It is lost.

Caudal furca. This limb has 7 pairs of claws and single unpaired bristle.

Male. It is unknown.

\section{Comparison}

A. orientalis nov. sp. differs from another species of this genus - A. simula in having a sculpture on the shell, greater number of posterior setae on the 1st segment of the

mandible endopodite, longer distodorsal seta on the 1st segment and longer dorsal seta on the 2nd segment of the 5 th limb, thinner of the 6 th limb and less number of claws on the furca.

Distribution

New species was captured in the North Pacific (37 $38^{\prime} 6-43^{\prime} 0 \mathrm{~N}^{\prime}$ and $\left.143^{\circ} 51^{\prime} 5-52^{\prime} 6 \mathrm{E}\right)$ between 2000 and $2500 \mathrm{~m}$.

\section{Archiconchoecemma simula (Deevey, 1982)}

Archiconchoecia simula Deevey, 1982: 137-140, figs. 6-12, tab. 1, 2; 1983: tab.1.

Archiconchoecia n. sp. Angel, 1981: 556, 561, fig. 194 (5A-H).

\section{Distribution}

Species was described from the South Ocean. It is known from the Pacific sector between 65$72^{\circ} \mathrm{S}$ and $160-180^{\circ} \mathrm{E}$ in depth range $1015-1829 \mathrm{~m}$ (Deevey, 1982) and from the Atlantic sector in the region $62-69^{\circ} \mathrm{N}$ and $75-85^{\circ} \mathrm{W}$ in depth $2196-2562 \mathrm{~m}$ (Deevey, 1983). Besides that, this species have been taken in the North Atlantic $\left(10^{\circ} 30 \mathrm{~N}-20^{\circ} 0 \mathrm{~W}\right.$ and $\left.20^{\circ} 0 \mathrm{~N}-21^{\circ} 0 \mathrm{~W}\right)$ between $1500-2000$ and 2500 4000 m (Angel, 1981; Deevey, 1982).

\section{Archiconchoecinna Chavtur gen. nov.}

Archiconchoecia Müller, 1912: 55 (part); Deevey, 1968: 22 (part).

Type species - Archiconchoecinna ecuneata Chavtur, new species

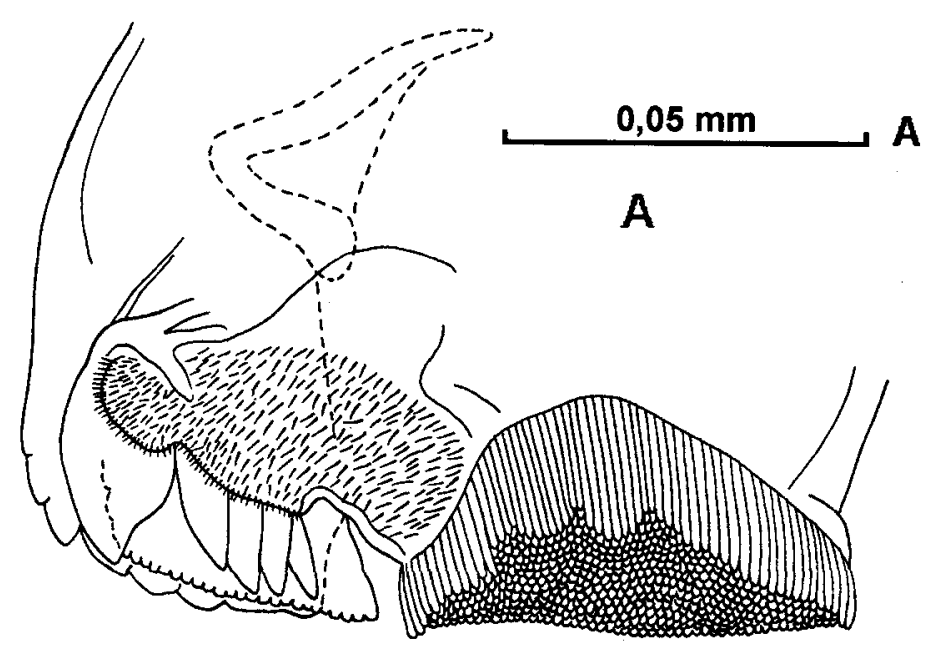

Fig. 24 Archiconchoecemma orientalis (female: 1118) A - toothrows and masticatory pad of coxa of mandible. 


\section{Composition}

This genus contains 5 species: A. ecuneata n. sp., A. cuneata (Müller, 1908), A. arctica n. sp., A. aff. cuneata 1 (A. cuneata in Deevey, 1968) and A. aff. cuneata 2 (A. cuneata in Deevey, 1978).

\section{Description}

Shell. Males range from 0.72 to $1.3 \mathrm{~mm}$ in length, and females from 0.82 to $1.25 \mathrm{~mm}$. Valves are slightly (considerably in A. cuneata - Müller, 1908) prolonged. Height of shells in male and female are $58-60 \%$ (52\% in A. arctica $\mathrm{n}$. sp.) and $50-60 \%$ of the length respectively. Greatest height of shell in male is at the anterior part and in female is at the posterior or subequal at both parts. Rostrum is developed and wide, and rostral incisure is not deep (deepened in A. cuneata - Müller, 1908). Dorsal margin is straight (slightly slopes downward at the posterior part in male $A$. aff. cuneata 2). Ventral and anterior margins are rounded. Posterior margin about 1/3-1/4 of the way down is straight, the rest of margin is slightly rounded and slopes downward to anteroventral side. Posterior margin is without tubercles and points. Left asymmetrical gland is located near posterodorsal corner (at corner in $A$. cuneata-Müller, 1908), and right gland is at $1 / 2$ or above of the shell height on the posterior margin. The shell has not visible sculpturing.

Frontal organ. It is slightly down-curved, short, barely extended beyond the down-curving distal segments of the 1st antenna in length. Organ in male and female are $60-70 \%$ and $80-90 \%$ the length of the 1st antenna on the dorsal side respectively. Capitulum section is not separated, is rounded or nearly rounded at the tip and without hairs and spinules.

First antenna. The limb is 6-jointed, with one dorsal seta placed on the 2nd segment. This seta is long, stout and coarsely spinous. Long 6 filaments placed on the 5th and 6th segments are equal in length, widened and pointed at the tip (distally not widened and rounded only in A. cuneata - Müller, 1908, Taf. 8, Fig. 4). Dorsal margin of the limb in the male and female are approximately $60-70 \%$ and $70-90 \%$ the length of filaments respectively. Height of antenna (on the 2nd segment) is about $20 \%$ (17-22\%) of the length. Hairs on the limb are missing (5th segment is covered with hairs in $A$. aff. cuneata 2 - Deevey, 1978c: 112).

Second antenna. The exopodite is shorter or about as long as the protopodite. The total length of the 2nd-9th segments of the exopodite is approximately 50-70\% of the 1st segment in length (35\% in A. arctica n. sp.). Basal segment is without warty surface and with or without hairs. The 2 nd segment is not covered with hairs, in male there are bristles "c" and "d" (without bristles in A. arctica n. sp.). The right clasper is narrow in the middle of the way (not narrow in A. arctica n. sp.). The right and left claspers are not distally tapering and have terminal thickening. The 5 filaments placed on the 2nd segment are distally widened or equal in thickness throughout, equal or unequal in length, pointed (rounded in $A$. arctica $\mathrm{n}$. sp.) at the tip and longer than the exopodite and about as long as the protopodite.

Mandible. The epipodite has no bristle. The exopodite is represented by very short spinous bristle (in A. ecuneata $n$. sp.) or without it. The 1st segment of the endopodite bears one dorsal and 4 ( 2 in $A$. arctica n. sp.) ventral setae, the 2 nd segment has 3 dorsal and 2 ventral setae. The 3 rd segment has 7 setae, of which the largest is claw-like and 1st dorsal seta shorter than the 2nd dorsal seta (both setae are slight). Main terminal claw-seta is shorter than the endopodite (on the dorsal side). Basale is armed with 2 anterior and 2 lateral setae, one anterolateral seta and anterior long hairs near the articulation. Basal endite has toothrow of 6 distinctly separated serrated teeth (with or without lateral tooth), and 2 short posterior setae.

Maxilla. The basal segment of the endopodite bears 6 ( 5 on one limb of male A. ecuneata $n$. sp.) anterior and 5 posterior setae. The distal segment is armed with 2 claw-setae and 3 usual setae.

Fifth limb. The quantity of setae placed on the epipodite is unknown. The 1st segment of the exopodite has 5-7 ventral and 2-3 dorsal, and the 2nd segment has 2 ventral and one (absent in $A$. arctica $n$. sp.) dorsal setae. The middle claw-seta of the 3rd segment is about $30-40 \%(60 \%$ in $A$. arctica $\mathrm{n}$. sp.) of the exopodite in length (on the dorsal side) and shorter or subequal in length to the 
dorsal claw-setae.

Sixth limb. The epipodial appendage has 3 groups of $5+5+6$ plumose setae (known only for $A$. ecuneata $\mathrm{n}$. sp.). The endopodite bears 2 (1-2 plumose) setae. The 1 st segment of the exopodite bears 0-2 dorsal and 5 ventral setae, the 2nd segment has only one ventral and the 3rd segment has one dorsal (claw-like) and one ventral setae. The 4th segment has dorsal and middle claw-setae and ventral usual seta. The middle claw-seta is $13-23 \%$ ( $43 \%$ in $A$. arctica $\mathrm{n}$. sp), and distodorsal seta (absent in A. arctica n. sp.) of the 1st segment is $10-25 \%$ in male and $15-35 \%$ in female of the exopodite in length (on the dorsal side). Height of the exopodite is $30-40$ in male and $35-40 \%$ in female of the length.

Seventh limb. It is unknown.

Copulatory appendage. It is tapering towards the tip. The greatest height is at the distal half or only at the base and is about $40-50 \%$ of the length (from tip to dorsomedial indentation). The tip is pointed and upward (rounded and not upward in A. arctica $\mathrm{n}$. sp.).

Caudal furca. This limb has 8 ( 7 in A. arctica n. sp.) pairs of claws. Furca is with (without in $A$. arctica $\mathrm{n}$. sp.) single unpaired bristle.

Remarks. A. arctica nov. sp. sharply separates from the description of Archiconchoecinna gen. nov. This species differs in many respects from other known species: " $c$ " and " $d$ " setae are lacking and the left clasper is short and thick on the endopodite of the 2nd antenna in male; the endopodite of mandible is only with 2 ventral setae placed on the 1st segment and without dorsal seta on the 2nd segment; longest terminal claw-setae of the 6th limb are longer, penis is not upward and is rounded at the tip. However, A. arctica nov. sp. is related to Archiconchoecinna in having shell "cuneata" shaped of shell and typical location of the asymmetric glands, the exopodite of the mandible has no seta, serrated teeth of the basale are distinctly separated; the 6th limb is armed with one on the 1st segment and 2 dorsal claw-setae on the 4th segments.

\section{Comparison}

New genus differs from all the other in following: exopodite of the mandibular has not seta, teeth on the basal endite of its limb are distinctly separated and serrated middle claw on the distal segment of the 5th and 6th limbs very short; and dorsal claw (or claw-like seta) on the 3rd segment of the exopodite of the 6 th limb is also very short.

This genus is close to Archiconchoecilla gen. nov., but distinct (in addition to the above side) on the following respects: the shell is higher in the anterior part; the basal endite of the mandible is armed with serrated teeth; greater number of the setae are placed on the 1st segment (posterior side) of the endopodite of the maxilla and on the endopodite of the 6th limb; distodorsal seta on the 1st segment of the 5 th limb and middle seta on the distal segment of the 6th limb are shorter.

Shell shape of Archiconchoecinna gen. nov. is close to Archiconchoecilla gen. nov., but differs from it by having symmetrical left and right valves, invisible sculpturing, and shorter (to the length of the protopodite) exopodite on the 2 nd antenna.

\section{Distribution}

Members of this genus were collected in a deep-sea zone of the tropical-subtropical Atlantic, boreal Pacific and central Arctic. The known depth range of the genus is $100(200)-3800 \mathrm{~m}$.

Key to Species of Genus Archiconchoecinna (Adult male and female)

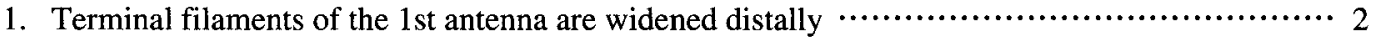

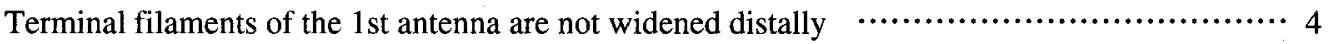

2. Terminal claw-setae of the 6 th limb are less than $25 \%$ of the exopodite in length (on the

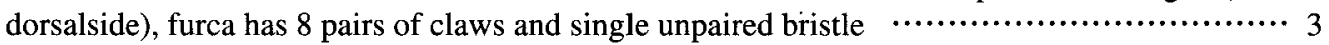
Terminal claw-setae of the 6 th limb exceed $40 \%$ of the exopodite in length, furca has 7 pairs of 
claws and lacks unpaired bristle

A. arctica n. sp.

3. Shell length is over $1 \mathrm{~mm}$, right asymmetrical gland is more half way up the posterior margin, exopodite of mandible has minute bristle and basal endite has lateral tooth, 1 st segment of the exopodite of 6 th limb bears one lateral seta A. ecuneata n. sp. Shell length is less than $1 \mathrm{~mm}$, right asymmetrical gland is approximately half way up the posterior margin, exopodite of mandible is without bristle and basal endite without lateral tooth, 1 st segment

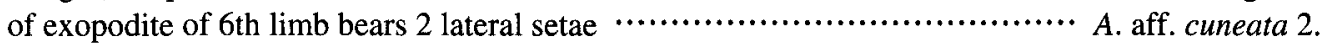

4. Left asymmetrical gland is located at the posterodorsal corner, bristle " $b$ " of 2nd antenna are shorter than its lst segment and is about $20 \%$ length of terminal filaments …... cuneata (Müller). Left asymmetrical gland is located near posterodorsal corner, bristle " $b$ " of 2nd antenna are longer than its 1 st segment and is over $50 \%$ length of terminal filaments

A. aff cuneata 1

\section{Archiconchoecinna ecuneata Chavtur sp. nov.}

(Figs. 25-28 and 31, A, B)

Archiconchoecia cuneata: Chavtur, 1992: table 2 (list).

Material examined

Holotype. N1119 - adult male, length $1.1 \mathrm{~mm}$, appendages are mounted on slide and valves remained in alcohol. In collection of the museum of Institute of Marine Biology, Vladivostok, Russia (together with paratype). Type-locality - R/V “Vityaz”, station 6111 , lat, $56^{\circ} 16^{\prime} 6-12^{\prime} 0 \mathrm{~N}, 138^{\circ} 20^{\prime} 0$ $137^{\circ} 17^{\prime} 8 \mathrm{~W}$, depth 1500-1000 m, 16 May 1966.

Paratype. N1120 - adult female, length $1.25 \mathrm{~mm}$; appendages are mounted on slide and valves remained in alcohol, from sample as in holotype.

Additional specimens - R/V "Vityaz", 1969: adult male (length $1.3 \mathrm{~mm}$ ), station $6118,56^{\circ} 26^{\prime}$ ' 9$28^{\prime} 0 \mathrm{~N}, 137^{\circ} 14^{\prime} 9-136^{\circ} 56^{\prime} 5 \mathrm{~W}$, depth $1000-500 \mathrm{~m}, 18$ May; 2 adult males ( 1.15 and $1.15 \mathrm{~mm}$ ), station $6139,53^{\circ} 11^{\prime} 5-21^{\prime} 5 \mathrm{~N}, 163^{\circ} 09^{\prime} 0-162^{\circ} 56^{\circ} \mathrm{OW}$, depth $2000-1500 \mathrm{~m}, 12$ June; juvenile $(1.05 \mathrm{~mm})$, station $6144,51^{\circ} 42^{\prime} 0 \mathrm{~N}, 167^{\circ} 55^{\prime} \mathrm{OW}$, depth $500-300 \mathrm{~m}, 17$ June.

All material (including holotype and paratype) were caught by Plankton Bogorov-Rass's Net $\left(\mathrm{S}=0.5 \mathrm{~m}^{2}\right)$.

Etymology

The specific name "ecuneata", from Latin "e" [=no] and "cuneata" [=narrowed], refers to closeness, but not identity to species A. cuneata (Muller, 1908).

Description of adult male

Shell (Fig. 25, A). Length in 1.1-1.3 mm. Valves are slightly prolonged. Height of shell is about $60 \%$ of the length. Greatest height is at the anterior part. Rostrum developed and wide, and rostral incisure is not deepened. Dorsal margin is straight and ventral and anterior margins rounded. Posterior margin about $1 / 4$ of the way down is straight, the rest of margin is slightly rounded and slopes downward to anteroventral side. This margin is without tubercles and points. Left asymmetrical gland is located near posterodorsal corner and right gland is at $1 / 2$ or above of the height on the posterior margin. Sculpturing on shell is invisible.

Frontal organ (Fig. 25, B, C). It is slightly curved, short, barely beyond the down-curving distal segments of the 1 st antenna and is approximately $60 \%$ of the 1 st antenna in length (of the dorsal side). Capitulum section is somewhat thicker than stem, down-curved, rounded at the tip and without hairs and spinules.

First antenna (Fig. 25, B, C). The limb is 6-jointed. Dorsal seta of the 2 nd segment is long, stout and coarsely spinous. The 5th and 6th segments bear 6 long filaments equal in length, distally widened and pointed at the tip. Dorsal margin of the limb is approximately $60 \%$ of the filaments length. Height of antenna (on the 2nd segment) is about $20 \%$ of its length. Hairs on the limb are absent. The 1 st segment has some dark pigment sports. 
Second antenna (Fig. 25, D-F). The exopodite is thick and shorter than the protopodite. The total length of the 2nd-9th segments of the exopodite is approximately $50 \%$ length of the 1 st segment. Basal segment of the endopodite is without hairs and warty surface; the bristle " $a$ " is thin, short and is $35-45 \%$ of the bristle " $b$ " in length. The bristles " $c$ " and " $d$ " of the 2nd segment are thin and long. The right clasper is narrow, curved, with short base (its thickness is same as in the middle part) and with slight terminal thickening. The left clasper is similar to the right but shorter than it. Claspers are rounded at the tip. The 5 filaments borne on the 2 nd segment are distally widened, unequal (?) in length, pointed at the tip and longer than the exopodite and protopodite.

Mandible (Figs. 26, A, B and 31, A, B). The epipodite is slightly (?) developed and without bristle. The exopodite is represented by very short spinous bristle. The 1st segment of the endopodite has straight dorsal margin and is armed with one dorsal and 4 ventral setae, the 2 nd segment with 3 dorsal and 2 ventral setae. The 3rd segment bears 7 setae, of which largest seta is claw-like and about $70 \%$ of the endopodite in length (on the dorsal side), 2 first dorsal setae are slight (the 1st shorter than the 2nd seta). Basale is armed with 2 anterior, 2 lateral, 1 anterolateral setae, and anterior row long hairs near the articulation. Basal endite has toothrow with 6 distinctly separated terminal teeth (5 serrated and one proximal bare triangular) and lateral tooth (triangular) tooth and 2 short posterior bristles. Coxale endite is armed with 3 closely set toothrows and tiny hairs. The masticatory surface is especially protuberant and bears rather large pointed denticles as well as bristles and with numerous long hairs.

Maxilla (Fig. 26, C, D). The basal segment of the endopodite bears 5-6 (all plumose) anterior and 5 (one plumose) posterior setae; plumose setae are armed with long proximal and short distal hairs. The 2nd segment has 2 claw-setae and 3 (one long and 2 short) usual setae.

Fifth limb (Figs. 26, E and 27, A). The epipodite is in poor condition. The 1st segment of the exopodite bears 5 ventral and 3 ( 2 plumose) dorsal setae, of which distodorsal seta is about $50 \%$ of the exopodite in length (on the dorsal side). Second segment is with 2 ventral and one dorsal setae, last seta is $40-45 \%$ and middle claw-seta of the $3 \mathrm{rd}$ segment is $35-40 \%$ of the exopodite in length. The terminal dorsal claw-seta is longer than the middle one. Ventral surface of the 1 st and 2 nd segments is covered with hairs.

Sixth limb (Fig. 27, B, C). The epipodial appendage has 3 groups of $5+5+6$ plumose setae. Two long plumose setae are placed on the endopodite. The 1st segment of the exopodite bears one very short (bare) dorsal and 5 ( 4 plumose) ventral setae. The 2 nd segment is with one ventral and the 3rd with one dorsal spinous claw-seta and one ventral ordinary seta. The 4th segment has one dorsal and one middle short claw-setae and one ventral very short usual seta, of which dorsal claw-seta is largest. Middle claw-seta of its segment is about $20 \%$ and distodorsal seta of the 1 st segment is $10-15 \%$ of the exopodite in length (on the dorsal side).

Height of the exopodite is about $40 \%$ of the length.

Seventh limb. It is lost.

Copulatory appendage (Fig. 25, G). Greatest height is at the distal half and is approximately $50 \%$ of the length (from tip to dorsomedial indentation). The tip is pointed and upturned. There is wedgelike muscle directed from the base to a pointed tip.

Caudal furca. This has 8 pairs of slim claws and single unpaired bristle.

\section{Descriptions of adult female}

Shell. It is in poor condition. Length is $1,25 \mathrm{~mm}$.

Frontal organ (Fig. 27, D). It is longer than in male and is about $80 \%$ of 1st antenna in length (on the dorsal side).

First antenna. (Fig. 27, D). Limb is about $70 \%$ of the terminal filaments in length. Height of antenna (on the 2 nd segment) is barely over $20 \%$ of the length.

Second antenna (Fig. 27, E, F). Terminal filaments are approximately equal and as long as the protopodite. 


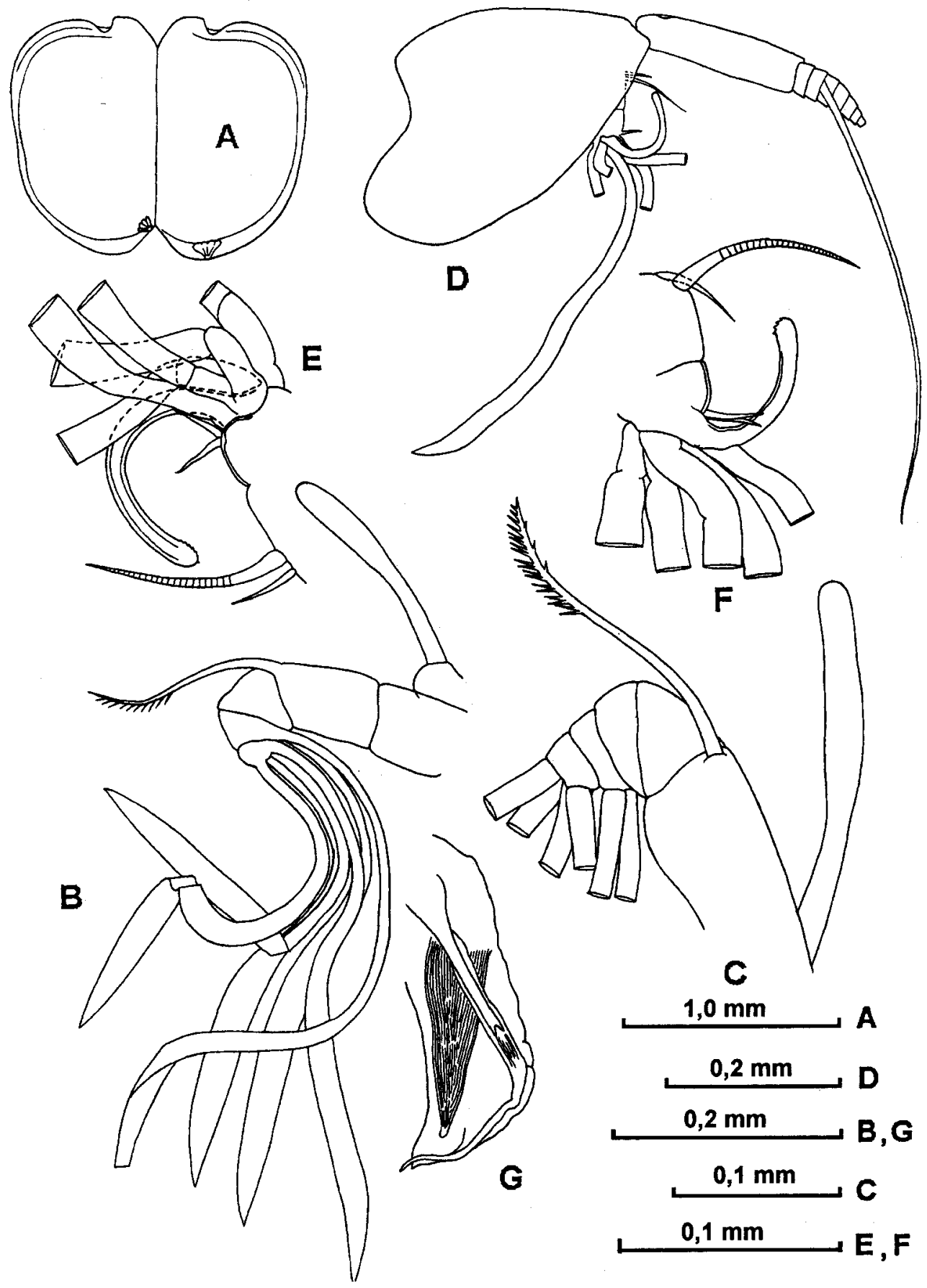

Fig. 25 Archiconchoecinna ecuneata sp. nov. (male: 1119) A - lateral view of shell, B and C - frontal organ 1st antenna, D - 2nd antenna, E and F - right and left endopodites of 2nd antenna, G - penis. 


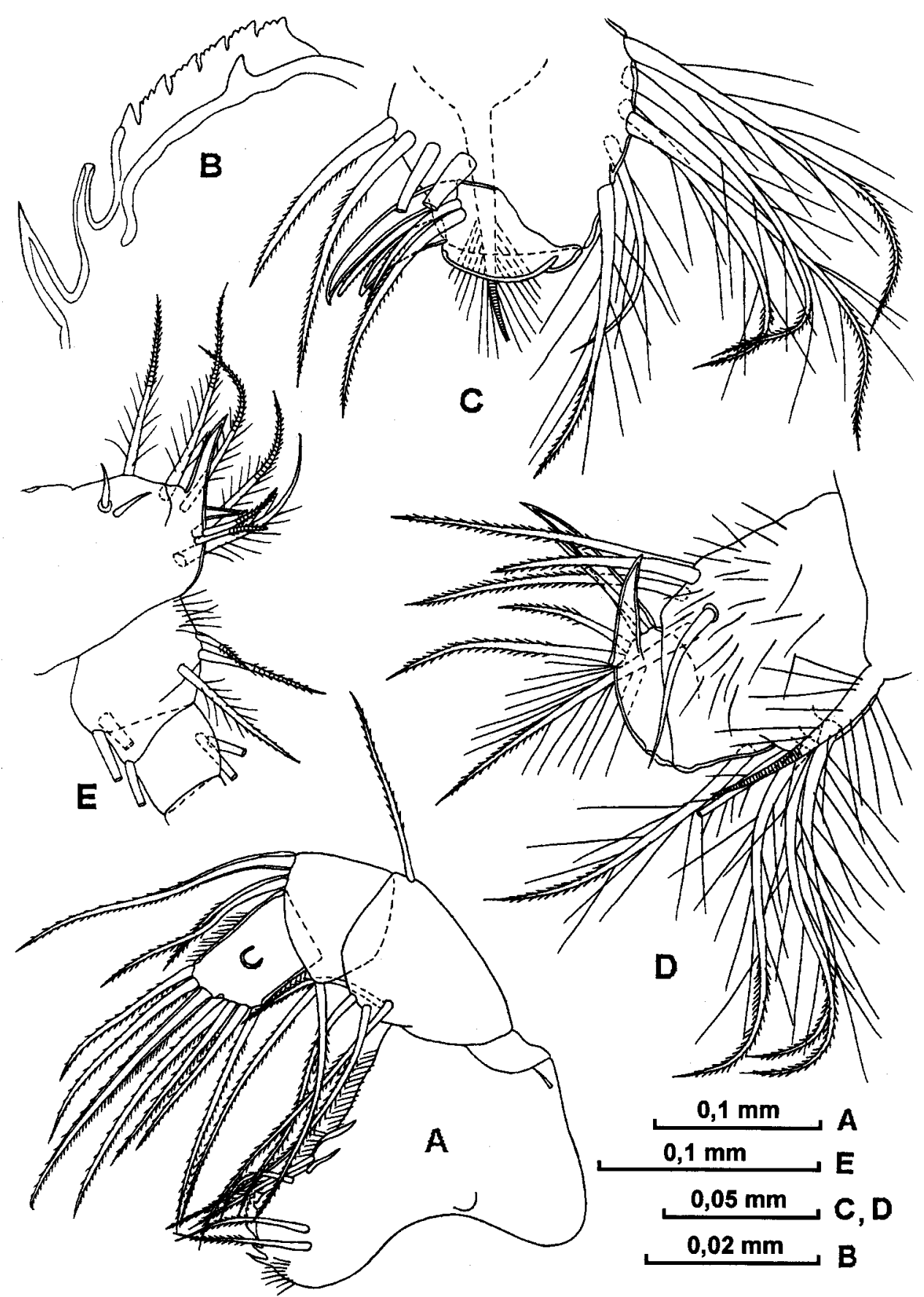

Fig. 26 Archiconchoecinna ecuneata sp. nov. (male: 1119) A - mandible B - basal endite of mandible, C and D - maxilla, E - proximal part of fifth limb. 


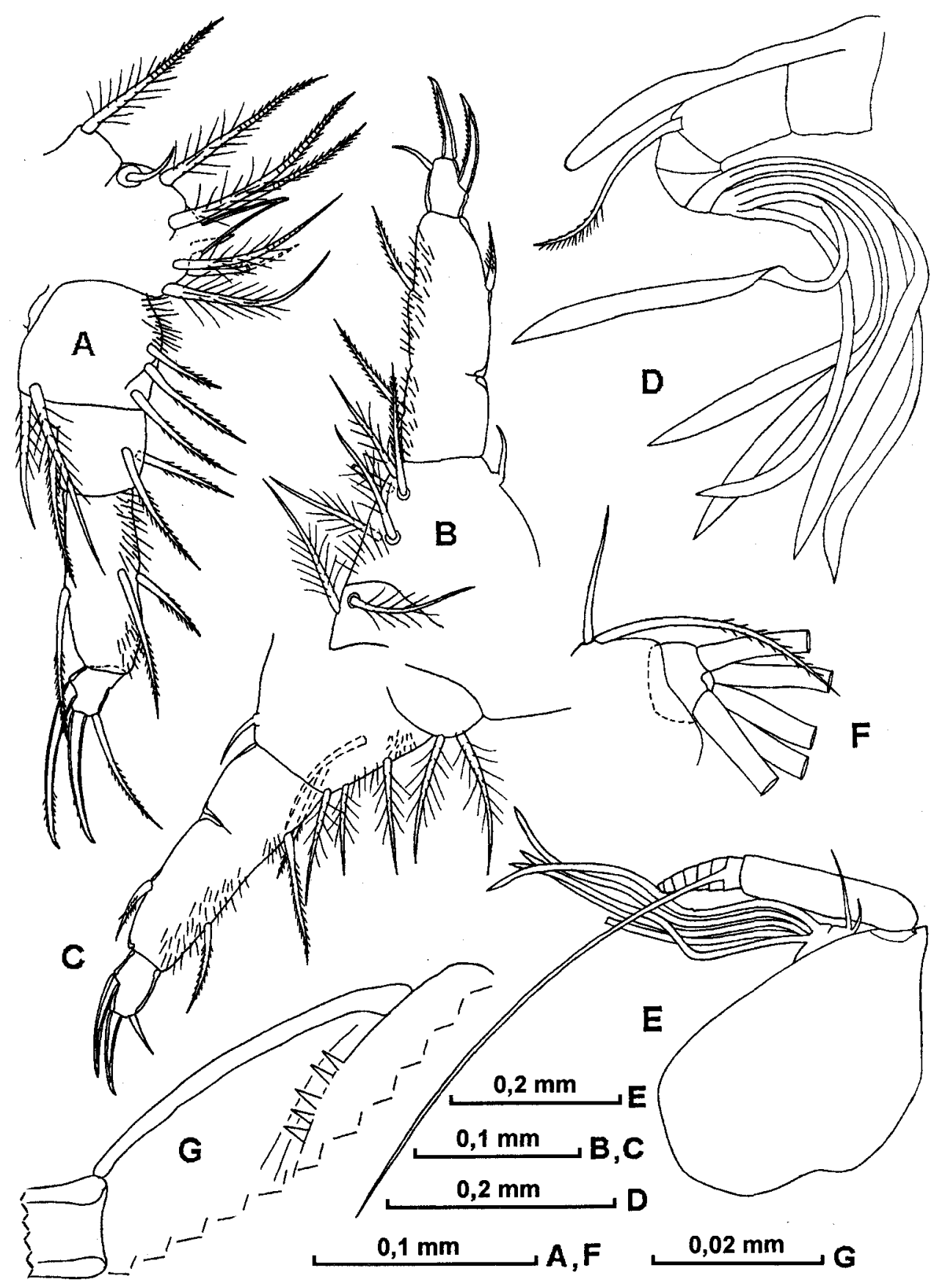

Fig. 27 Archiconchoecinna ecuneata sp. nov. (male: 1119 - A-C, female: 1120 - D-G) A - fifth limb, B and C - sixth limb, D - frontal organ and 1st antenna, E - 2nd antenna, F - endopodite 2nd antenna, $\mathrm{G}$ - distal arming of 1st segment of endopodite maxilla. 


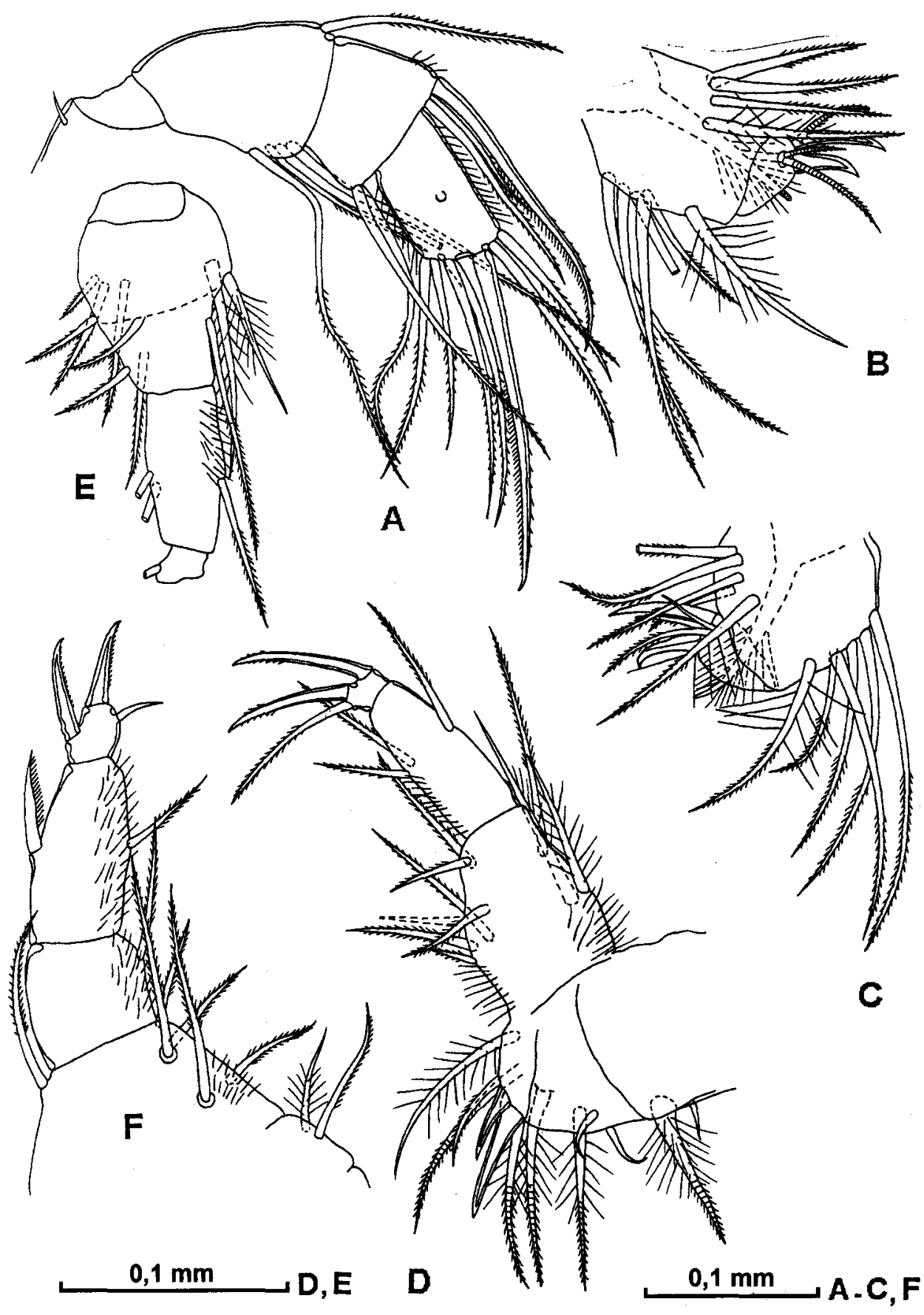

Fig. 28 Archiconchoecinna ecuneata sp. nov. (female: 1120) A - mandible, B and C - maxilla, D - fifth limb, E - endopodite fifth limb, F - sixth limb. 
Mandible (Fig. 28, A). Main terminal claw-seta is scarcely over $70 \%$ of the endopodite in length (on the dorsal side)

Maxilla (Figs. 27, G and 28, B, C). One seta of other 5 anterior setae placed on the basal segment is plumose.

Fifth limb (Fig. 28, D, E). The 1st segment of exopodite bears 7 ventral and 3 dorsal setae, of which distodorsal seta is $65 \%$ of the exopodite in length (on the dorsal side).

Sixth limb (Fig. 28, F). The endopodite is with one long common and one short plumose setae. Setae placed on the 1st exopodite are nonplumose. Claw-setae of the 4th segment are thicker and claw-seta of the 3rd is thicker and longer than in male. Distodorsal seta on the 1st segment is longer and about $35 \%$ of the exopodite in length (on the dorsal side). Height of the exopodite is $45-50 \%$ of the length.

Seventh limb. It is lost.

Caudal furca. As in male.

\section{Comparison}

The new species is closest to $A$. aff. cuneata 2 , but differs in many respects: shell is longer, right asymmetrical gland is located more half of the way up the posterior margin; frontal organ is somewhat shorter; the 1st segment of the exopodite on the 2nd antenna is longer than its 2nd-9th segments, terminal filaments on the endopodite of the 2nd antenna are longer (to the length of its exopodite and protopodite); the exopodite of the mandible is represented by very short spinous bristle (it is lacking in $A$. aff. cuneata 2), the basal endite on the mandible is armed with additional lateral tooth (it is missing in $A$. aff. cuneata 2); plumose setae placed on the maxilla have longer hairs; the 1st segment of the exopodite on the 6th limb bears one ( 2 in $A$. aff. cuneata 2 ) dorsal seta, the 6th limb is thicker.

\section{Distribution}

New species was captured in the Gulf of Alaska and in the region of the Aleutian Trench at water depth of 300 to $2000 \mathrm{~m}$.

\section{Archiconchoecinna arctica Chavtur sp. nov.}

(Figs. 29, 30 and 31, C, D)

Archyconchoecia cuneata: Chavtur, 1978: 1791-1793.

Archiconchoecia species nov. Chavtur, 1991: 94; 1992: table 2 (list).

Holotype. N1 121 - adult male, length $1.05 \mathrm{~mm}$, appendages and valves are mounted on slide. In collection of the Museum of Institute Marine Biology, Vladivostok, Russia. Type-locality - Drifting Station "North Pole - 2", $81^{\circ} 29 \mathrm{~N}$ and $197^{\circ} 16 \mathrm{E}$, depth 3800-995 m, 3 April 1951 Nansen' s (Plankton Net).

Etymology

The specific name from the locality of the holotype.

Description of adult male

Shell (Fig. 29, A). Length is $1.05 \mathrm{~mm}$. Valves are slightly prolonged. Height of shell is about $50 \%$ of the length. Greatest height is at the anterior part. Rostrum is developed and wide, and rostral incisure is not deepened. Dorsal margin is straight and ventral and anterior margins rounded. Posterior margin is approximately $1 / 4$ of the way down straight, the rest of margin is slightly rounded and strongly slopes downward to anteroventral side; it is without tubercles and points. Left asymmetrical gland is located near posterodorsal corner, and right gland is located above the shell height on the posterior margin. Sculpture on the shell is not visible.

Frontal organ (Fig. 29, B, C). It is slightly curved, short, and slightly beyond the down-curving distal segments of the 1st antenna (\% the length of the 1st antenna is unknown since the proximal part 


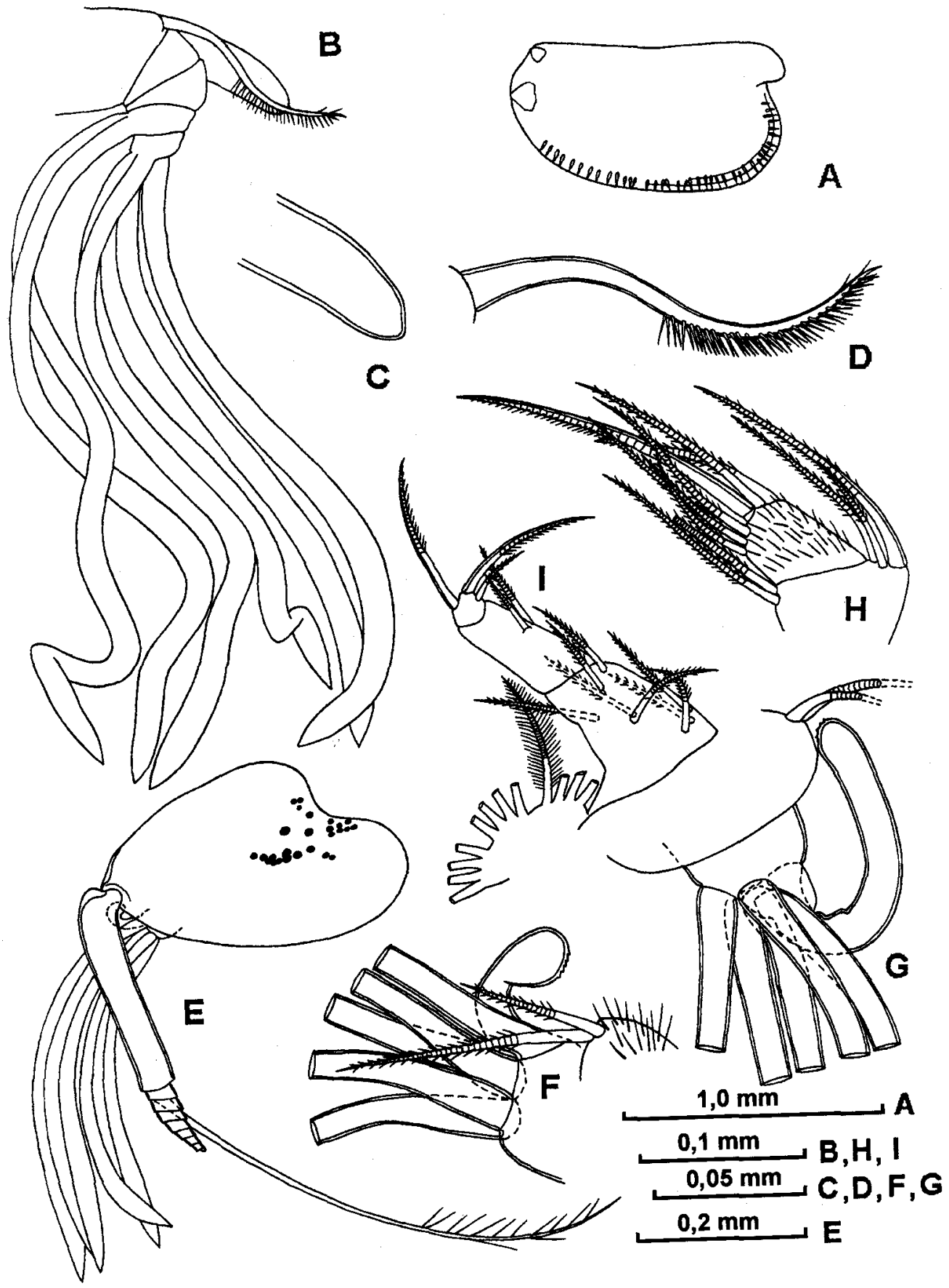

Fig. 29 Archiconchoecinna arctica sp. nov. (male: 1121) A - lateral view of right valve of shell, B - distal part of frontal organ of 1st antenna, C - distal part of frontal organ, D - dorsal seta of 1st antenna, E - 2nd antenna, F and $\mathrm{G}$ - endopodite 2 nd antenna, $\mathrm{H}$ - distal part of endopodite mandible, I fifth limb. 


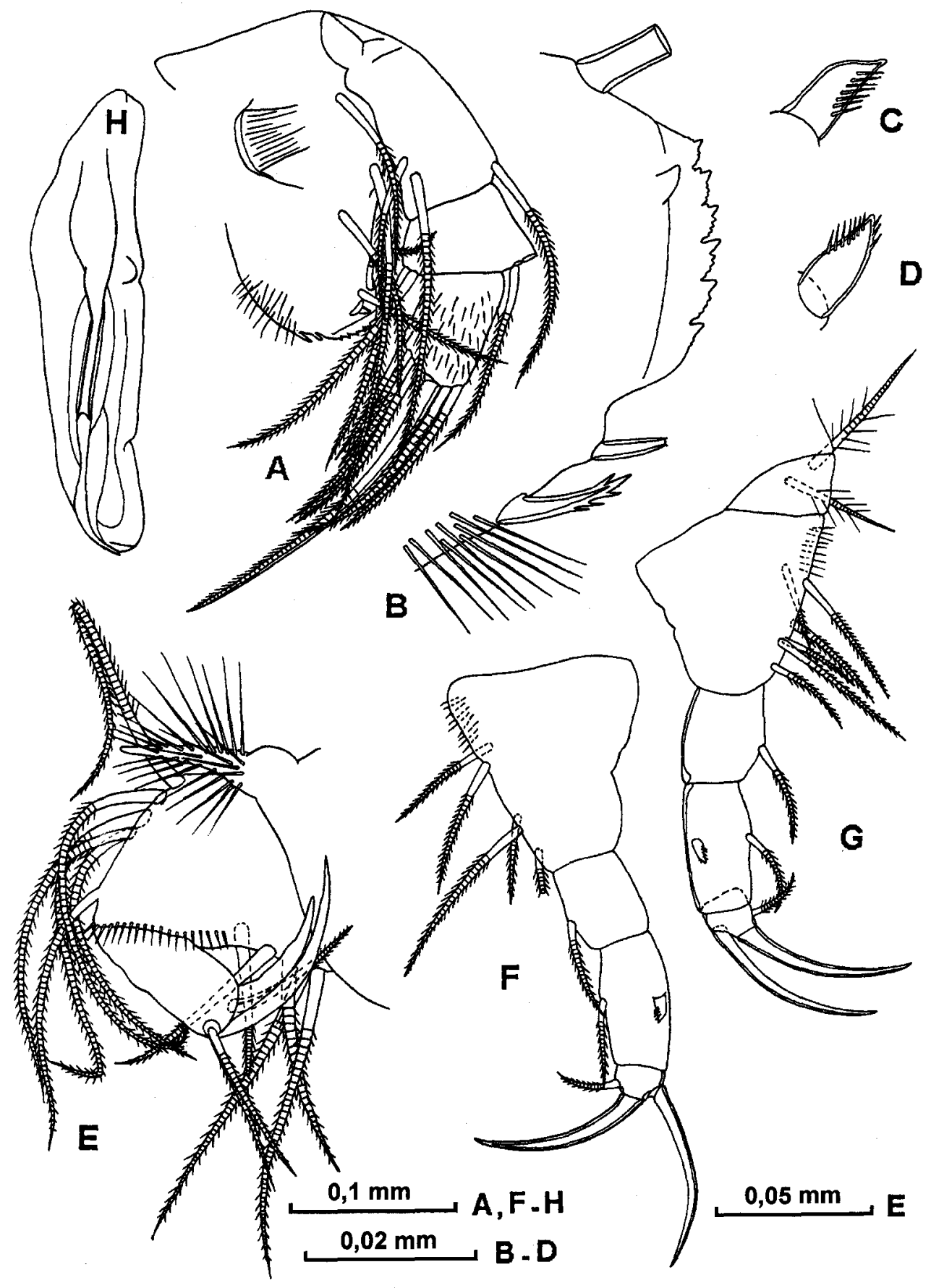

Fig. 30 Archiconchoecinna arctica sp. nov, (male: 1121) A - mandible, B - basal endite of mandible, C and D - dorsal claw-seta of 3rd segment of exopodite of sixth limb, E - maxilla, F and G - sixth limb, $\mathrm{H}$ - penis. 
of the 1 st antenna is broken). Capitulum section is rounded at the tip and without hairs and spinules (proximal part of frontal organ is torn).

First antenna (Fig. 29, B, D). The limb is 6-jointed. It has one long, stout and coarsely spinous dorsal seta on the 2 nd segment. Six long filaments placed on the 5 th and 6 th segments are equal in length, which are distally widened and pointed at the tip (\% the length and height of the filaments from the length limb and the presence of pigment sports are unknown since 1st segment is broken). Hairs on the limb are absent.

Second antenna (Fig. 29, E-G). The exopodite is thick and subequal to protopodite in length. The total length of the 2nd-9th segments of the exopodite is approximately $35-40 \%$ of the 1 st segment in length. Basal segment of the endopodite is without hairs and warty surface, and the bristles "a" and " $b$ " are thin and short ("a" is about $60 \%$ of "b" in length). There are no bristles "a"-"c" on the 2nd segment. The right clasper is stout, relatively wide, curved, with short base (its thickness as in the middle part) and with slight terminal thickening. The left clasper is also stout, but considerably shorter and with large terminal thickening. Claspers are rounded at the tip. The 5 filaments of the 2nd segment are distally widened, approximately equal in length, pointed at the tip and longer than the exopodite and protopodite.

Mandible (Figs. 29, H; 6, A, B and 31, C, D). The epipodite is developed and without bristle. The

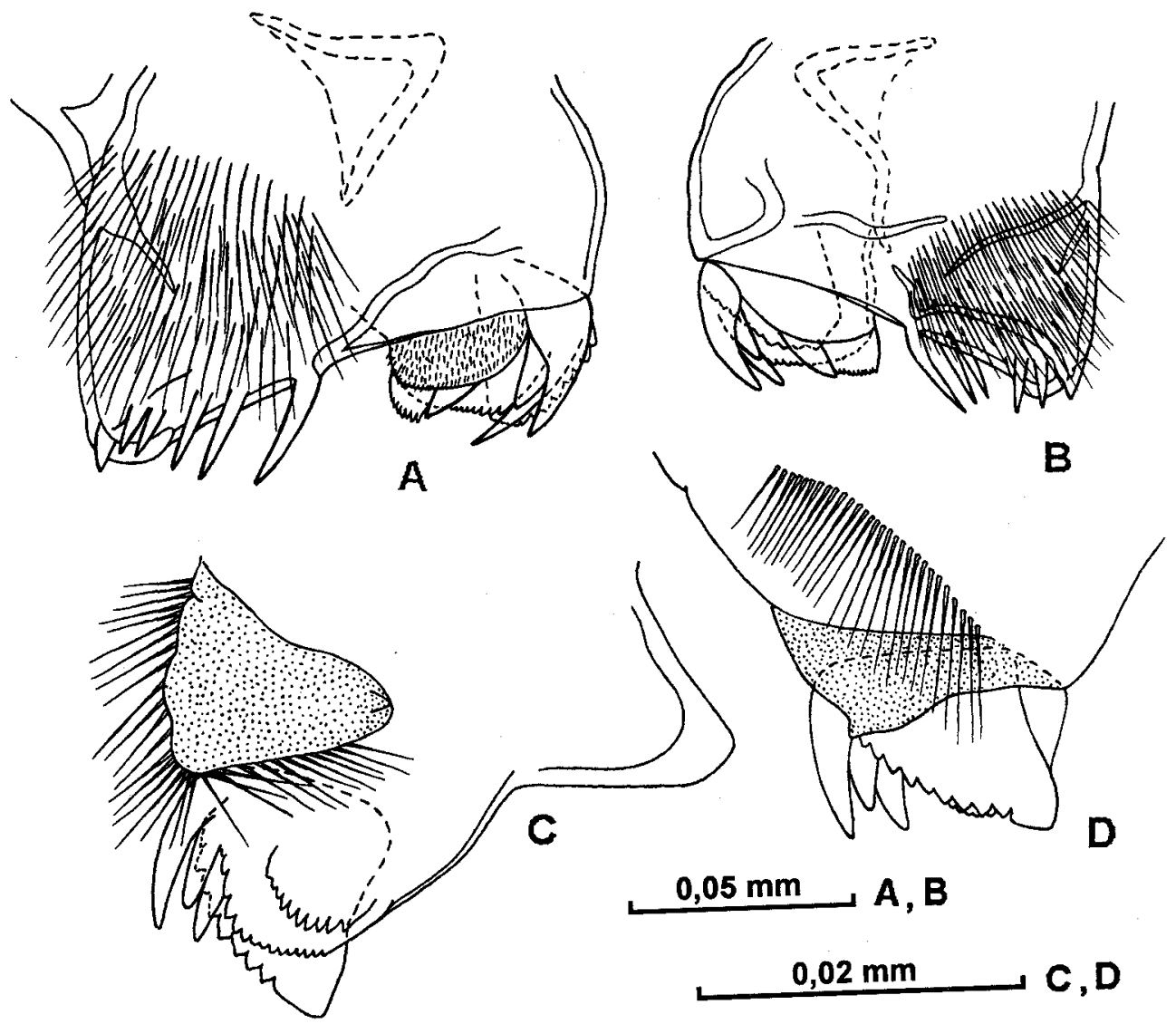

Fig. 31. Archiconchoecinna ecuneata sp. nov. (male: 1119 - A, female:1120 - B), A. arctica n. sp. (male: 1121 - C-D) A-D - toothrows and masticatory pad of coxa of mandible. 
exopodite is also without bristle. The 1st segment of the endopodite has straight dorsal margin and is armed with one dorsal and 2 ( 4 in Chavtur, 1978 is not correct) ventral setae, the 2nd segment is with 3 dorsal and 2 ventral setae. The 3rd segment bears 7 setae, of which largest seta is claw-like and about $80 \%$ of the endopodite in length (on the dorsal side) and 2 first dorsal setae are slight (the 1st is shorter than the 2nd seta). Basale is armed with 2 anterior and 2 lateral setae, one anterolateral seta and anterior row long hairs near the articulation. Basal endite has toothrow with 6 distinctly separated serrated terminal and one triangular lateral teeth and 2 short posterior setae. Coxal endite is armed with 3 toothrows. The masticatory pad is protuberant (?) and bears small rounded terminal denticle and a.row of long hairs.

Maxilla (Fig. 30, E). The basal segment of the endopodite has 6 anterior and 5 posterior nonplumose setae and also a distal row of long spines near the articulation. The 2 nd segment is armed with 2 claw-setae and 3 usual (short) setae.

Fifth limb. The epipodite is torn. The 1st segment of the exopodite has 6 ventral and 2 dorsal nonplumose setae, of which distodorsal seta is about $50 \%$ of the exopodite in length (on the dorsal side). The 2 nd segment has only 2 ventral setae. The middle claw-seta of the 3 rd segment is approximately $60 \%$ of the exopodite in length. The terminal dorsal claw-seta is about as long as the middle one. The limb has no hairs.

Sixth limb (Fig. 30, C, D, F, G). The epipodite is in poor condition. Two long plumose are placed on the endopodite. The 1st segment of the exopodite has 5 (all nonplumose) ventral only. The 2nd segment with one ventral seta and the 3 rd has one minute pectinate claw-like and one usual ventral setae. The 4th segment is armed with one dorsal and one middle long claw-setae and one usual very short ventral seta, of which dorsal claw-seta is the largest, and middle claw-seta is $40-45 \%$ of the exopodite in length (on the dorsal side). Height of the exopodite is $35 \%$ of the length.

Seventh limb. It is lost.

Copulatory appendage (Fig. 30, H). Greatest height is at the base and about $35 \%$ of the length (from tip to dorsomedial indentation). Penis is tapering from the base towards the tip. The tip is rounded and upturned. No muscles are noted on the penis.

Caudal furca. This limb has 7 pairs of claws and no unpaired bristle.

Female. Unknown.

\section{Comparison}

New species is separated from all other members of the genus (see the "Comparison" for the description of this genus). It is somewhat close to $A$. ecuneata nov. sp., but differs by longer 1 st segment of exopodite on the 2nd antenna, lesser number of ventral setae are placed on the 1st segment of the mandible endopodite, absence of the dorsal seta is on the 2nd segment of the exopodite of the 5 th limb and on the 1 st segment of the exopodite of the 6th limb, longer terminal claw-setae are on the 5th and 6th limbs, lesser number of the claws and absence of the unpaired bristle on the furca, and also it differs by the shape of the penis.

\section{Distribution}

New species was caught in the central Arctic only in a tow from 935 to $3800 \mathrm{~m}$.

\section{Archiconchoecinna cuneata (Müller, 1908)}

Archiconchoecia cuneata Müller, 1908: 63-64, Taf. 8, Fig. 1-4; 1912: 55.

Archiconchoecia cuneata: Angel, Fasham, 1975: 736; Angel, 1979: 79-80; Chen and Lin, 1994a: 448, 450.

Not Archyconchoecia cuneata: Chavtur, 1978: 1791-1793, fig. 2, 1-11. 
Distribution

Species was described from South Atlantic $\left(19^{\circ} 3 \mathrm{~S}-20^{\circ} 0 \mathrm{~W}\right)$ in a tow from 800 to $0 \mathrm{~m}$. Probably it inhabits the North Atlantic between $40-18^{\circ} \mathrm{N}$ in the depth range 200-1250 m (Angel, 1979; Angel, Fasham, 1975) and North-West Pacific near Philippines in the deep zone (also a small amount of this species appeared in the 0-150 $\mathrm{m}$ layer of this area, resulting from the upwelling effects (Chen and Lin, 1994a).

\section{Archiconchoecinna aff. cuneata 1}

Archiconchoecia cuneata: Deevey, 1968: 26, fig. 6; 1971: 231; Deevey, Brooks, 1980: 45, 60 (part).

Remarks

This species differs from A. cuneata by a larger height of shell, shorter rostrum, and smaller depth of rostral incisure, low position of the left asymmetrical gland; longer " $b$ " bristle and shorter filaments placed on the epipodite of the 2 nd antenna.

Distribution

The species was taken in the Sargasso Sea from 400-100 and 500-0 m.

\section{Archiconchoecinna aff. cuneata 2}

Archiconchoecia cuneata: Deevey, 1978c: 107, 111, 112-115, figs. 3, 4.

\section{Remarks}

This species differs from A. cuneata in the following: larger shell height, shorter rostrum, and smaller depth of rostral incisure, low location of the left asymmetrical gland; filaments with distal widened on the 1st antenna, and longer " $b$ " bristle on the 2 nd antenna.

It differs from $A$. aff. cuneata 1 in having a distally widened filaments of the 1 st antenna, and longer filaments on the endopodite of the 2nd antenna.

Distribution

Species has been taken only in the Sargasso Sea from 1000 to $500 \mathrm{~m}$.

\section{Archiconchoecetta Chavtur gen. nov.}

Archiconchoecia Müller, 1906: 43-44 (part); Poulsen, 1969: 14-15 (part).

Type-species - Archiconchoecia ventricosa Müller, 1906.

\section{Composition}

This genus consists of 11 species: A. ventricosa (Müller, 1906), A. poulseni (Deevey, 1978), A. fabiformis (Deevey, 1978), A. bimucronata (Deevey, 1978), A. bispicula (Deevey, 1978), A. bifurcata (Deevey, 1978), A. gastrodes (Deevey, 1978), A. falcata (Deevey, 1978), A. pilosa (Deevey, 1978), A. bidens (Deevey, 1982), A. inventricosa $\mathrm{n}$. sp.

\section{Description}

Shell. Males range from 0.8 to $1.7 \mathrm{~mm}$ in length, female from 0.9 to $1.9 \mathrm{~mm}$. Valves are slightly or fairly prolonged. Height of shell in male and female are $54-61 \%$ and $47-58 \%$ of the length, respectively. Greatest height of male is at the anterior part, and in the female it is approximately equal at the anterior and posterior parts (highest at anterior part only in female of A. inventricosa $\mathrm{n}$. sp). Rostrum is not developed and narrow, and rostral incisure is deepened. Dorsal margin of male is straight and slopes downward to posterior end and in female it is barely swollen or straight (for $A$. inventricosa $\mathrm{n}$. sp. same as in male). Anterior margin is straight and extends beyond rostrum. 
Posterior margin is evenly rounded or slopes downward at the upper part, without tubercles and points. Left asymmetrical gland is located at posterodorsal corner, right gland of male is about. $30-40 \%$ and female $40 \%$ of the way up the posterior margin (no indication of asymmetrical glands for A. bidens). Slight indication of sculpturing is, as lines parallel to the ventral margin (at an angle of $45^{\circ}$ to this margin in A. poulseni) or sculpturing invisible on the shell (A. bifurcata, A. gastrodes, A. falcata).

Frontal organ. It is straight or slightly down-curved, slightly or considerably extended beyond the down-curving distal segments of the 1st antenna (organ lost in A. gastrodes). Organ in male and female is $85-100 \%$ and $90-110 \%$ of the 1 st antenna in length (of the dorsal side) respectively. Capitulum section is not separated or separated, with 1-2 thin needle-like prolongations or rounded at the tip, and with or without hairs.

First antenna. The limb is 6-jointed, with one long, stout and coarsely spinous dorsal seta on the 2nd segment. Six long filaments on the 5th and 6th segments are equal in length, which are distally widened or not and pointed or rounded (only in A. ventricosa - Muller, 1906) at the tip. Dorsal margin of the limb is about $50-80 \%$ of the filament in length. Height of antenna (on the 2nd segment) is about $20 \%(17-22 \%)$ of the length. Hairs on the limb are missing.

Second antenna. The exopodite is thin or relatively thick and shorter than the protopodite. The total length of the 2nd-9th segments of the exopodite is approximately $35-50 \%$ of the 1 st segment in length. Basal segment is without warty surface. The 2 nd segment is without hairs in female (with hairs in A. fabiformis) and bears usual bristles " $\mathrm{c}$ " and " $\mathrm{d}$ " in male. The right clasper is narrow in the middle. The right and left claspers are not distally tapering, with or without terminal thickening and rounded at the tip. The 5 filaments placed on the 2 nd segment are approximately equal in thickness throughout (distally widened in A. bidens), equal or unequal in length, pointed at the tip (rounded in $A$. ventricosa - Müller, 1906, Taf. 7, Fig. 5), and longer than the exopodite and protopodite.

Mandible. The epipodite is without bristle. The exopodite is represented by one short or midlong seta. The 1st segment of the endopodite has one dorsal and 4 (3-4 in A. inventricosa n.sp.) ventral setae, the 2 nd segment with 3 dorsal and 2 ventral setae. The 3 rd segment bears 7 setae, of which largest seta is claw-like and 2 first dorsal setae are slight (they probably are claw-like in $A$. pilosa and $A$. falcata), the 1st dorsal seta is longer than the 2nd dorsal seta. Main terminal claw-seta is shorter, equal or longer than the endopodite in female (on the dorsal side) and shorter in male. Basale is armed with 2 lateral setae, 2 anterior (4 in A. fabiformis), one anterolateral setae and anterior row long hairs near the articulation. Basal endite has toothrow with 6 ( 7 in A. poulseni) slightly separated serrated teeth and 2 short posterior bristles.

Maxilla. The basal segment of the endopodite bears 5-6 anterior and 4-6 posterior setae. The distal segment has 3 ( 4 in A. poulseni) usual setae and 2 claw-setae (posterior claw-seta shorter than the distal one in $A$. ventricosa and longer than in others species).

Fifth limb. The epipodite has 3 groups of $4+4+4(5)$ plumose setae. The 1 st segment of the exopodite bears 5-8 ventral and 2-3 dorsal and 2 nd segment is with 2 ventral and one dorsal setae. The middle claw-seta of the $3 \mathrm{rd}$ segment is $50-90 \%$ of the exopodite in length (on the dorsal side) and longer than its dorsal seta.

Sixth limb. The epipodial appendage has 3 groups of $5+5+6$ in male and $4(5)+4(5)+5(6)(13-16$ totally) in female plumose setae. Two (only one in A. fabiformis) plumose setae are placed on the endopodite. The 1 st segment of the exopodite is armed with 1-2 dorsal and 4-5 ventral setae, the 2 nd segment has only one ventral seta and the 3 rd has one dorsal and one ventral setae. The 4 th segment has 2 usual setae and one middle claw-seta (it is lacking in juv. A. falcata). This claw-seta is about 50$110 \%$ (20\% in A. pilosa) in male and $50-100 \%$ in female and distodorsal seta of the 1 st segment is about $15-40 \%$ in male and $25-40 \%$ in female of the exopodite in length (on the dorsal side). Height of the exopodite is $15-40 \%$ of the length.

Seventh limb. It is varying in size and shape.

Copulatory appendages. It is tapering towards the base and the tip from the middle. Highest is at the middle and about $40-50 \%$ of the length (from tip to dorsomedial indentation). The tip is rounded 
(small protuberance is placed at the tip in A. pilosa).

Caudal furca. This limb has 7-8 pairs of claws and single unpaired bristle.

Remarks. Morphology of A. pilosa considerably deviates from the description of this genus in the following: left clasper of the 2nd antenna is thick and short; ventral seta on the distal segment of 5th limb is longest (middle seta in others species); distal segment of 6 th limb bears 2 short claws (one in others species). This structure is such as in genus Archiconchoecina. However some indications point out the relationship to the new genus: character "ventricosa"-shape and sculpturing of the shell, presence of seta on the exopodite and slight separation of teeth on the basal endite of the mandible, presence of one long dorsal and one medial setae on the distal segment of the 5th limb and usual dorsal seta on the 3rd segment of the endopodite of the 6th limb.

\section{Comparison}

New genus differs from other genera in having the anterior margin extended beyond rostrum, low location of right asymmetrical gland (usually less than $1 / 2$ of the shell height on the posterior margin), very thin claspers on 2 nd antenna and slightly separated teeth on the basale endite of the mandible.

It is more close to genus Archiconchoecia, but differs (in addition to the above characters) by short rostrum, developed seta on the mandibular exopodite and usual (not claw-like) dorsal seta placed on the 3 rd segment of the exopodite of 6 th limb.

\section{Distribution}

Members of this genus have been collected in of all oceans (except the Arctic ocean) and the Sargasso and Caribbean Seas. The northernmost and southernmost latitudes are $51^{\circ} \mathrm{N}$ and $72^{\circ} \mathrm{S}$. Most species were caught from 500 (1000) to $2000 \mathrm{~m}$. Only A. bifurcata was taken from $500(1000)-3700$ $\mathrm{m}$ and $A$. inventricosa nov. sp. - from between 3000 and $5500 \mathrm{~m}$.

\section{Key to Species of Genus Archiconchoecetta}

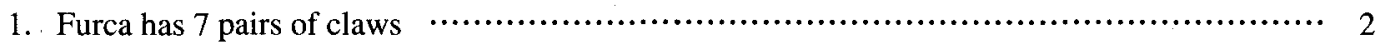

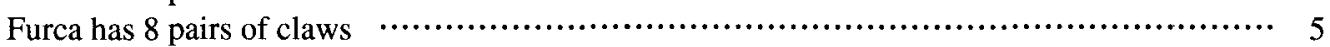

2. Shell length is less than $1.1 \mathrm{~mm}, 1 \mathrm{st}$ segment of maxilla bears 4 posterior setae $\cdots \cdots \cdots \cdots \cdots \cdots \cdots$

Shell length is over $1.4 \mathrm{~mm}, 1 \mathrm{st}$ segment of maxilla bears $5-6$ posterior setae $\cdots \cdots \cdots \cdots \cdots \cdots \cdots \cdots$

3. Frontal organ has 2 terminal needle-like extensions; 1 st segment of exopodite of fifth limb bears 2 dorsal and 6 ventral setae, its terminal claw-seta is approximately $90 \%$ of exopodite in length (on the dorsal side) …................................. . bispicula (Deevey) Frontal organ is with one terminal needle-like prolongations; 1 st segment of exopodite of fifth limb bears 3 dorsal and 6 ventral setae, its terminal claw-seta is approximately $70 \%$ of exopodite in length ............................................... ventricosa (Müller)

4. Shell in female is highest at the anterior part, basal endite of mandible is armed with a row of 6 teeth, 1 st segment of its endopodite bears 6 anterior and 6 posterior setae; posterior claw-seta is longer than the anterior on the 2 nd segment of maxilla ..........................

Height of shell in female is equal at anterior and posterior parts, basale endite of A. inventricosa new species. mandible is armed with a row of 7 teeth, 1 st segment of its endopodite bears 5 anterior and 5 posterior setae; posterior claw-seta is shorter than anterior one on the 2 nd segment

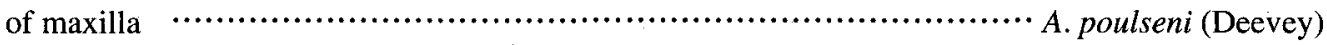

5. Ventral seta placed on the distal segment of fifth limb is longest, 6th limb is with 2 short claws A. pilosa (Deevey)

Medial seta placed on the distal segment of fifth limb is longest, 6th limb has one long claw

6. 1st segment of endopodite of maxilla has 9-10 setae, 1st segment of exopodite of 5th 
limb has 5 ventral setae

1st segment of endopodite of maxilla has 11-12 setae, 1st segment of exopodite of 5 th limb has 6-8 ventral setae

7. Frontal organ has 2 terminal needle-like prolongations; basale of mandible has 2 anterior setae, 1st segment of endopodite of maxilla bears 9 setae $\cdots \cdots \cdots$. . bimucronata (Deevey) Frontal organ lacks terminal prolongations; basale of mandible has 4 anterior setae, 1 st segment of endopodite of maxilla bears 10 setae A. fabiformis (Deevey)

8. Shell length is less than $1.4 \mathrm{~mm}$, terminal filaments of 1 st antenna are not distally widened A. falcata (Deevey)

Shell length is over $1.5 \mathrm{~mm}$, terminal filaments of $1 \mathrm{st}$ antenna are distally widened $\cdots \cdots . . . \cdots \cdot . . .9$

9. 1st segment of endopodite of maxilla has 11 (5 plumose) setae, 1 st segment of exopodite of 5 th limb has 6 ( 4 plumose) ventral setae 1 st segment of endopodite of maxilla has 12 (all nonplumose) setae, 1st segment of exopodite of 5 th limb has 7-8 (one plumose) setae A. bidens (Deevey)

10. Distal surface of endopodite of maxilla is armed with some spinules; only female - shell height is over $50 \%$ of length, main terminal claw-seta of mandible is shorter than its endopodite (on the dorsal side), exopodite height of 6 th limb is approximately $40 \%$ of length A. bifurcata (Deevey)

Distal surface of endopodite of maxilla is without spinules; only female-shell height is less $50 \%$ of length, main terminal claw-seta of mandible is longer than its endopodite, exopodite height of 6 th limb is less $20 \%$ of length A. gastrodes (Deevey)

\section{Archiconchoecetta inventricosa Chavtur sp. nov.}

(Figs. 32-34)

Archyconchoecia ventricosa: Chavtur, 1977a: 142, 158, fig.8, table 6, 1977b: table 2; 1977c: table 2. Archiconchoecia aff. ventricosa Chavtur, 1991: 49.

Archiconchoecia sp. nov. Chavtur, 1992: table 2 (list).

Material examined

Holotype. N1122 - adult female, length $1.9 \mathrm{~mm}$, appendages are mounted on slide and preserved valves in alcohol. In collection of the Museum of Institute of Marine Biology, Vladivostok, Russia (together with paratype). Type-locality - R/V “Vityaz", station $6144,51^{\circ} 42 \mathrm{~N}, 167^{\circ} 55 \mathrm{~W}$, depth 5500 $3300 \mathrm{~m}, 17$ April (Plankton Bogorov-Rass's Net, $\mathrm{S}=0.5 \mathrm{~m}^{2}$ ).

Paratype. 1123 - adult female, length $1.5 \mathrm{~mm}, \mathrm{R} / \mathrm{V}$ "Vityaz", station $5621,45^{\circ} 06 \mathrm{~N}, 155^{\circ} 55 \mathrm{E}$, depth 4000-3000 m, 17 August, Plankton Bogorov-Rass' s Net, $S=1.0 \mathrm{~m}^{2}$ (appendages are mounted on slide and valves remained in alcohol).

Etymology

The species name "inventricosa", from the Latin "in" [=no] and "ventricosa" [big - bellied], refers to closeness, but not identity with species $A$. ventricosa (Müller, 1906).

Description of adult female

Shell (Fig. 32, A). Length is in 1.5-1.9 mm. Valves are slightly prolonged. Height of shell is 58$60 \%$ of the length. Greatest height is at the anterior part. Rostrum is not developed and narrow, and rostral incisure deepened. Dorsal margin is almost straight and slopes downward to posterior end. Ventral margin is straight or barely concave. Anterior margin is rounded and considerably extended beyond rostrum. Posterior margin is evenly rounded. Left asymmetrical gland is located at posterodorsal corner, right gland is approximately at $30 \%$ of the way up the posterior margin. Slight indication of sculpturing, is as wavy lines paralleling the ventral margin.

Frontal organ. (Fig. 32, B). It is almost straight, narrow, considerably extended beyond the 
down-curving distal segments of the 1st antenna and is approximately $90-95 \%$ of the 1 st antenna in length (on the dorsal side). Capitulum section is unseparated, with 2 thin and small needle-like prolongations at the tip and without hairs.

First antenna. (Fig. 32, B-D). The limb is 6-jointed. Dorsal seta of the 2 nd segment is long, stout and coarsely spinous (proxidorsally and distoventrally) and with short hairs (distodorsally and proximoventrally). Six long filaments on the 5th and 6th segment are in equal length, which are distally widened and pointed at the tip. Dorsal margin of the limb is about $60 \%$ of the filament in length. Height of antenna (on the 2 nd segment) is nearly $20 \%$ of the length. Hairs and pigment spots on the limb are missing.

Second antenna (Figs. 32, F and 33, A). The exopodite is relatively thick and shorter than the protopodite. The total length of the 2nd-9th segments of the exopodite is approximately $40 \%$ of the 1 st segment in length. Basal segment is without hairs and warty surface, the bristles " $a$ " and " $b$ " are thin and armed with long hairs, bristle " $a$ " is about twice as long as the "b" bristle. Bristles "c"-"e" on the 2 nd segment are lacking. The 5 filaments placed on this segment have an equal length and thickness throughout, pointed at the tip, and longer than the exopodite and protopodite.

Mandible (Figs. 33, B, C and 34, G, H). The epipodite is slightly developed and without bristle. The exopodite is represented by one midlong seta. The 1st segment has straight dorsal margin and bears one dorsal and 3-4 ventral setae, the 2nd segment has 3 dorsal (usual type) and 2 ventral setae. The 3rd segment is armed with 7 setae, of which the largest is claw-like and about as long as the endopodite (on the dorsal side), and 2 first dorsal setae are slight (the 1 st shorter than the 2 nd seta). Basale bears 2 lateral setae, 2 anterior, one anterolateral setae and anterior row long hairs near the articulation. Basal endite has toothrow with 6 slightly separated serrated teeth and 2 short posterior bristles. Coxale endite is armed with 3 toothrows, 4 rounded denticles and some tiny hairs. The masticatory pad is flat and bears 2 very wide rounded denticles, terminal row of short filaments and numerous long hairs.

Maxilla (Fig. 33, D, F). The basal segment bears 6 unplumose anterior and 6 (one plumose) posterior setae. The distal segment has 2 claw-setae and 3 (one lateral is short) usual setae.

Fifth limb (Fig. 34, A). The epipodite has 3 groups of $4+4+5$ (one short) plumose setae. The 1 st segment of the exopodite has 7 ventral and 3 dorsal setae, of which distodorsal seta is approximately $65 \%$ of the exopodite in length (on the dorsal side). The 2 nd segment has 2 ventral and one dorsal setae, last seta is about $30 \%$ and middle claw-seta of the 3 rd segment is $55 \%$ of the exopodite in length. Two other terminal setae are slight and short.

Sixth limb (Fig. 34, B-E). The epipodial appendage is armed with 3 groups of $5+4+6$ (one short) plumose setae. Two short plumose setae are borne on the endopodite. The 1 st segment of the exopodite has 2 dorsal and 5 ventral setae, its distodorsal seta about half the length of the exopodite (on the dorsal side). The 2 nd segment is with one ventral and the 3 rd segment with one dorsal and one ventral setae. The 4th segment has 2 thin setae and middle claw-seta, the last is longest them and about $50 \%$ of the exopodite is length. Height of the exopodite is approximately $30 \%$ of the its length.

Seventh limb (Fig. 3, F). It is medium in length and thickness (25\% of the length) and prolonged. The longest seta is about twice as long as the short seta and 3 times as long as the limb.

Furca (Fig. 34, G). This limb has 7 pairs of claws and single unpaired bristle.

\section{Comparison}

The new species differs from other species of this genus in having a greatest height of the shell at the anterior half. It is closely related to A. ventricosa and A. bispicula. The new species differs from the first species in the following: the shell is larger and less prolonged; frontal organ is with 2 thin and small needle-like prolongations at the tip; filaments of the 1st antenna are widened distally; the 1 st segment of the maxilla exopodite has more posterior setae; and the 1st segment on the exopodite of the 5 th limb has more ventral setae. New species differs from A. bispicula in the following: the shell is larger; terminal claw-seta on the mandible is longer; and in 5th and 6th limbs this claw-seta is shorter, 

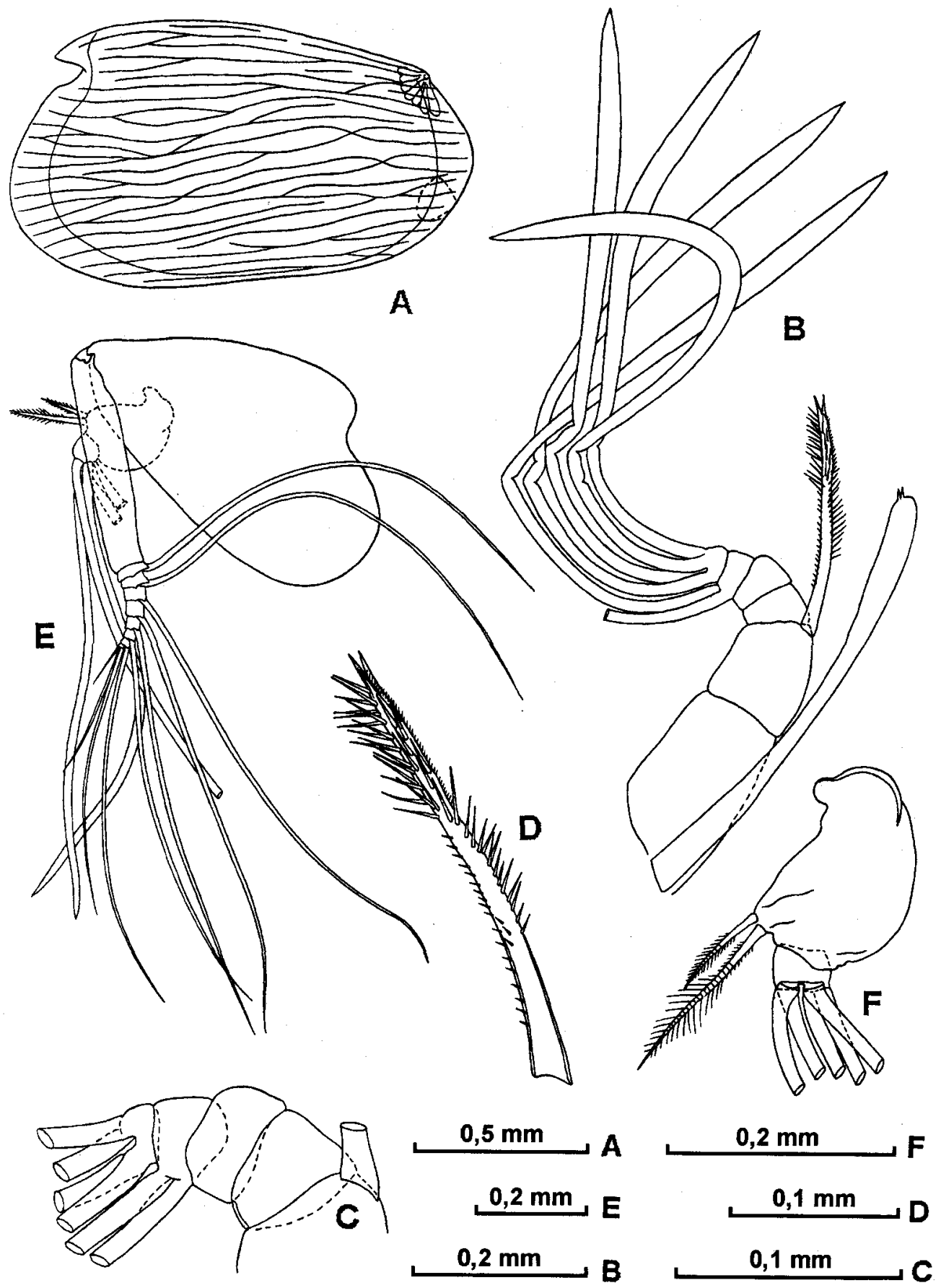

Fig. 32 Archiconchoecetta inventricosa sp. nov. (female: 1123 - A; 1122 - B-F) A - lateral view of left valve of shell, B - frontal organ and 1st antenna, C - distal part of 1st antenna D - dorsal seta of 1st antenna, E - 2nd antenna, F - endopodite 2nd antenna. 


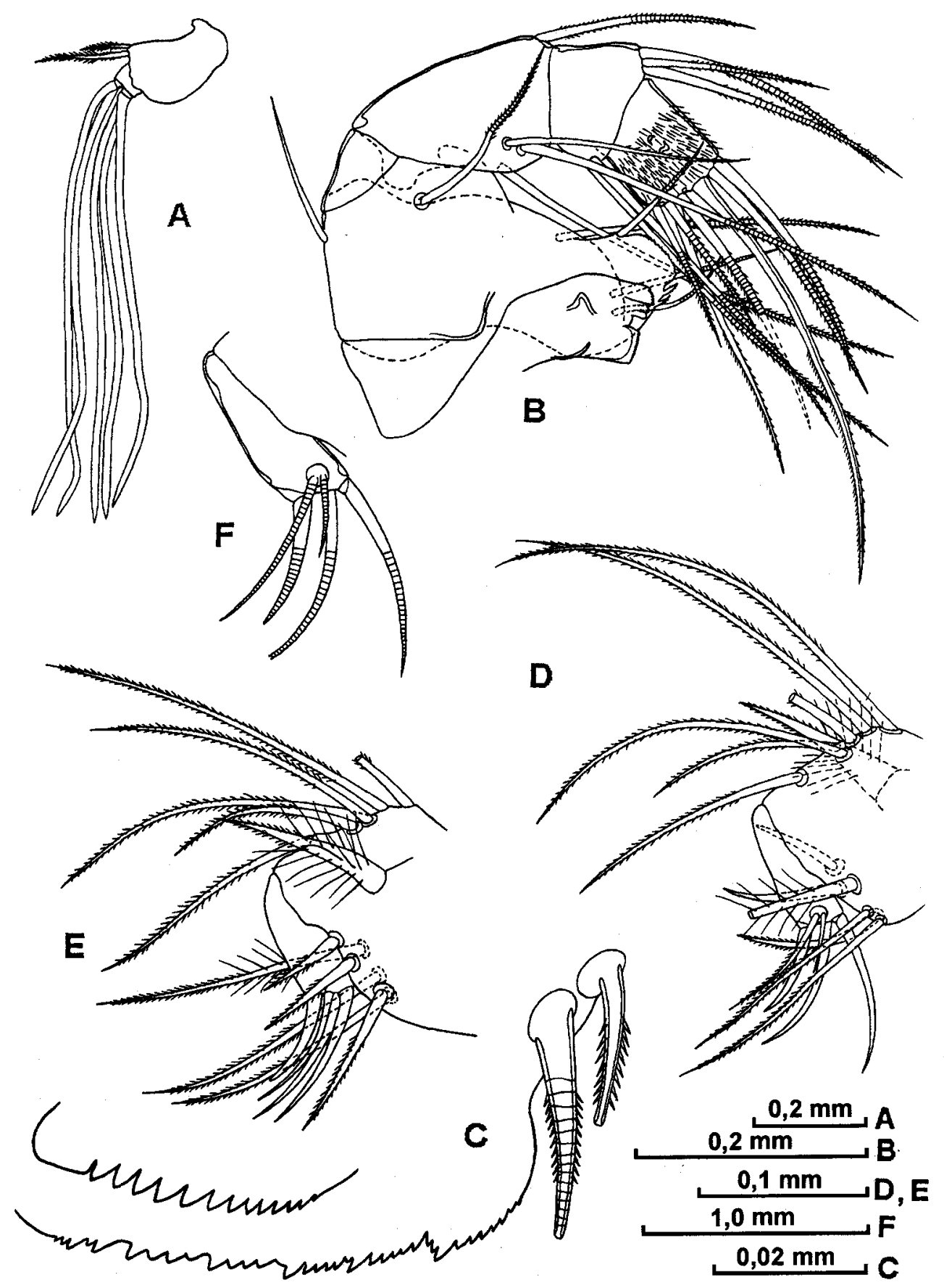

Fig. 33 Archiconchoecetta inventricosa sp. nov. (female: 1122 - A, C-F; 1123 - F) A - endopodite of 2nd antenna, B - mandible, C - basale endite of mandible, D and E - maxilla, F - distal part of endopodite of maxilla. 


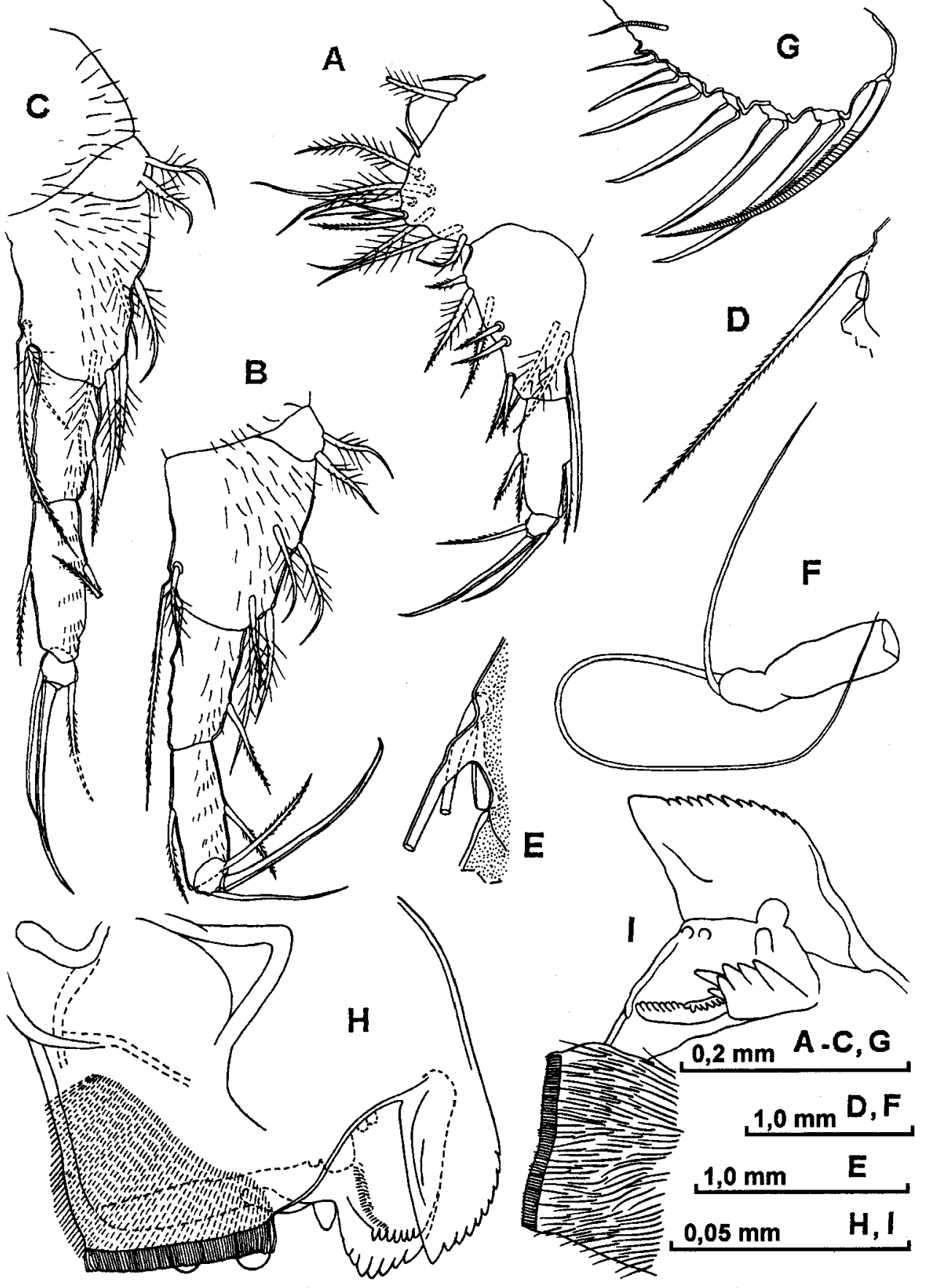

Fig. 34 Archiconchoecetta inventricosa sp. nov. (female: 1122 - A-E; 1123 - F-I) A - fifth limb, B and C sixth limb, D and E - distolateral seta of 1st segment of exopodite sixth limb and proximal part of this segment, F - seventh limb, G - furcal lamella, H and I - toothrows and masticatory pad of coxa of mandible. 
and the rest as is the case with A. ventricosa.

Distribution

New species has been taken in the Kurile - Kamchatka and Aleutian Trenches between 3000 and $5500 \mathrm{~m}$.

\section{Archiconchoecetta ventricosa (Müller, 1906)}

Archiconchoecia ventricosa Müller, 1906: 45-46, Taf. 7, Fig. 1-6; 1908: 63; 1912: 55; Alcaraz, Manriquez and Vasquez, 1975: 381, 382; Alcaraz, 1977: 9; Angel and Fasham, 1975: 716-718, 720, tab. 2-4; Angel, 1977: 243; 1979: 120, 121; Deevey, 1978a: 63-67, Figs. 4, 5; Deevey and Brooks, 1980: 63-65, Fig. 10a-c; McKenzie, Duccasse, Dufour and Peypouquet, 1979: 2; Drapun, 1981:75; Angel, 1993: 80, Fig.27.

? Archiconchoecia ventricosa: Angel, 1981: 556, 562, Fig. 194-7 (A-H).

Not Archiconchoecia ventricosa: Poulsen, 1969: 21-24, figs. 5-7.

Not Archyconchoecia ventricosa: Chavtur, 1977a: 142, 158, fig. 8, tab. 6; 1977b: tab.2; 1977c: table. 2.

Remarks

Probably, specimens noted by Angel (1981) are not A. ventricisa, since the frontal organ is without terminal long spine (description and illustrations of many appendages are missing in this publication).

Distribution

Species inhabits the Atlantic Ocean in the latitudes range $44^{\circ} \mathrm{N}-24^{\circ} \mathrm{S}$ (NE Atlantic - Müller, 1906; 1912; Alcaraz et al., 1975; Alcaraz, 1977; Angel and Fasham, 1975; Angel, 1977; 1979; McKenzie et al., 1979. NW Atlantic - Deevey, 1978a; Deevey and Brooks, 1980; Angel, 1979. S Atlantic - Müller, 1908; Drapun, 1981). Also it was taken in the Indian Ocean from $7^{\circ} \mathrm{N}-85^{\circ} \mathrm{W}$ (Müller, 1906). It is known from levels in the depth range $2000-500 \mathrm{~m}$ and in tows from $3500 \mathrm{~m}$ to the surface. Angel (1993) reported that $A$. ventricosa is widespread (but never common) and occurs in the Indian and Atlantic Oceans between $0^{\circ}-49^{\circ} \mathrm{N}$.

\section{Archiconchoecetta poulseni (Deevey, 1978)}

Archiconchoecia ventricosa: Poulsen, 1969: 21-24, figs. 5-7.

Archiconchoecia poulseni Deevey, 1978c: 106, 107.

Remarks

Deevey (1978c) singled out new species since “...Poulsen's female differs from Muller's specimens in size, the shape of frontal organ, and in the number of other ways, it is here renamed as $A$. poulseni n. sp." In addition, A. poulseni is separated from $A$. ventricosa in the following: shell is twice as long as that in $A$. ventricosa; frontal organ is with 2 (one in A. ventricosa) long terminal spines; basale endite is armed with 7 ( 6 in $A$. ventricosa) teeth, posterior seta is longer than anterior seta on the 2nd segment of the maxilla endite (shorter in A. ventricosa). Besides, these species differ by sizes and setation of all the limbs.

Distribution

Collected in the South Pacific $\left(22^{\circ} 43 \mathrm{~S}-166^{\circ} 06 \mathrm{E}\right.$ and $\left.28^{\circ} 18 \mathrm{~S}-177^{\circ} 01 \mathrm{E}\right)$ from levels $1500-50 \mathrm{~m}$ (3000-100 $\mathrm{mw})$ and 500-50 $\mathrm{m}(1000-100 \mathrm{mw})$. 


\section{Archiconchoecetta bidens (Deevey, 1982)}

Archiconchoecia bidens Deevey, 1982: 140-143, figs. 13-15.

Distribution

Species has been taken only in the Southern Ocean (71 $\left.{ }^{\circ} 57 \mathrm{~S}-179^{\circ} 58 \mathrm{E}\right)$ from $1600-1400 \mathrm{~m}$.

\section{Archiconchoecetta fabiformis (Deevey, 1978)}

Archiconchoecia fabiformis Deevey, 1978a: 59-63, Figs. 2, 3.

Distribution

Species was caught in the Sargasso Sea $\left(11^{\circ} 45 \mathrm{~N}-66^{\circ} 56 \mathrm{~W}\right)$ in a tow from $1200-0 \mathrm{~m}$.

Archiconchoecetta bimucronata (Deevey, 1978)

Archiconchoecia bimucronata Deevey, 1978c: 128-131, Figs. 13-14; 1983: 411; Deevey, Brooks, 1980: 65, Fig. 10e, f.

Distribution

Known from the North Atlantic $\left(32^{\circ} 0 \mathrm{~N}-64^{\circ} 30 \mathrm{~W}\right.$ ) between 1500-1000 m (Deevey, 1978b; Deevey, Brooks, 1980) and from the South Pacific (42²8 S-long) in level 2000-1000 m (Deevey, 1983).

\section{Archiconchoecetta bispicula (Deevey, 1978)}

Archiconchoecia bispicula Deevey, 1978c: 123-125, Fig. 10; Deevey, Brooks, 1980: 63, 65, Fig. 10g.h.; Ellis, 1985: 928; Angel, 1993: 68, Fig. 21.

\section{Distribution}

Species was described from the Caribbean Sea $\left(17^{\circ} 18 \mathrm{~N}-85^{\circ} 27 \mathrm{~W}\right.$, in a vertical tow, probably from around $2000 \mathrm{~m}$ ). Later, it has been taken in the North Atlantic from region $32^{\circ} 10 \mathrm{~N}-64^{\circ} 30 \mathrm{~W}$ between 1000 and $500 \mathrm{~m}$ (Deevey and Books, 1980) and $49^{\circ} \mathrm{N}-13^{\circ} \mathrm{W}$ in 900 to $800 \mathrm{~m}$ (Ellis, 1985). Angel (1993) reported that A. bispicula known from $17^{\circ}-53^{\circ} \mathrm{N}$ in the North Atlantic (a rare benthopelagic / deep mesopelagic species usually taken at $800-1500 \mathrm{~m}$ ).

Arhciconchoecetta bifurcata (Deevey, 1978)

Archiconchoecia bifurcata Deevey, 1978c: 131-134, Figs. 15,16; 1983: 411; Deevey and Brooks, 1980: 62-63, 65, Fig. i, j.

Distribution

Species was caught in the Sargasso Sea $\left(32^{\circ} 10 \mathrm{~N}-64^{\circ} 30 \mathrm{~W}\right)$ from levels $1000-500$ and $1500-1000$ $\mathrm{m}$ (Deevey, 1978c; Deevey, Brooks, 1980) and in the Pacific sector of the Southern Ocean $\left(62^{\circ} 20 \mathrm{~S}-\right.$ ? long) from 3700-3500 m (Deevey, 1983).

\section{Archiconchoecetta gastrodes (Deevey, 1978)}

Archiconchoecia gastrodes Deevey, 1978c: 134-137, Figs. 17-18; Deevey, Brooks, 1980: 65, Fig. 10d; Angel, 1983: 552, 1993: 76, Fig. 25; Ellis, 1985: 929.

Distribution

Collected in the Sargasso Sea from region $32^{\circ} 10 \mathrm{~N}-64^{\circ} 30 \mathrm{~W}$ in the level $1500-1000 \mathrm{~m}$ (Deevey, $1978 \mathrm{c}$; Deevey, Brooks, 1980) and in the North Atlantic from $42^{\circ} \mathrm{N}-17^{\circ} \mathrm{W}$ (Angel, 1983) and $44^{\circ} \mathrm{N}-$ $13^{\circ} \mathrm{W}$ (Ellis, 1985) between $2700-1500$ and $1650-800 \mathrm{~m}$ respectively. 


\section{Archiconchoecetta falcata (Deevey, 1978)}

Archiconchoecia falcata Deevey, 1978c: 125-128, Figs. 11, 12; 1983: 411; Deevey, Brooks, 1980: 43, 65; Chen and Lin, 1994b: 416, table 2.

\section{Distribution}

This species was caught in the Sargasso Sea $\left(32^{\circ} 10 \mathrm{~N}-64^{\circ} 30 \mathrm{~W}\right)$ from $2000-1000 \mathrm{~m}$ (Deevey, $1978 \mathrm{c}$; Deevey and Brooks, 1980), in the Pacific sector of the Southern Ocean (56 S-? long) from $1830 \mathrm{~m}$ (Deevey, 1983), and in the central South China Sea in the depth range 1000-4000 $\mathrm{m}$ (Chen and Lin, 1994b).

\section{Archiconchoecetta pilosa (Deevey, 1978)}

Archiconchoecia pilosa Deevey, 1978c: 115-119, Figs. 5,6; 1983: 411; Deevey, Brooks, 1980: 63, tab. 2; Ellis, 1985: 929.

\section{Distribution}

Species was collected in the Sargasso Sea from the region $32^{\circ} 10 \mathrm{~N}-64^{\circ} 30 \mathrm{~W}$ (Deevey, 1978c; Deevey, Brooks, 1980) and the North Atlantic from $49^{\circ} \mathrm{N}-13^{\circ} \mathrm{W}$ (Ellis, 1985) between 2000-1500 and 600-500 m, respectively. Also, it was taken in the South Pacific ( $37^{\circ} \mathrm{N}-$ ? long) between 1000 and 500 $\mathrm{m}$ (Deevey, 1983). Angel (1993) reported that this is a rare bathypelagic species which known from $10^{\circ}-49^{\circ} \mathrm{N}$ in the North Atlantic.

\section{Archiconchoecerra Chavtur gen. nov.}

Type-species - Archiconchoecia longiseta Deevey, 1978.

Composition

This genus contains only $A$. longiseta (Deevey, 1978).

\section{Description}

Shell. Females range from $1.27-1.3 \mathrm{~mm}$ in length, male unknown. Valves are prolonged. Greatest height of the shell is at the posterior part and around $60 \%$ of the length. Rostrum is developed and wide, and rostral incisure is not deepened. Dorsal margin is straight, ventral, anterior and posterior margins are rounded. Posterior margin is without tubercles and points. Clear lens-like structure is near posteroventral corner of each valve. Left asymmetrical gland is near posterodorsal corner, right gland is $1 / 3$ to $1 / 2$ of the way up the posterior margin. The shell has not visible sculpture.

Frontal organ. It is slightly down-curved and considerably extended beyond the down-curving distal segments of the 1st antenna and is approximately $90 \%$ of this antenna in length (on the dorsal side). Capitulum section is not separated or barely separated, with 1-2 tiny points at the tip and with tiny ventral hairs.

First antenna. The limb is 6-jointed, with one long, stout and coarsely spinous dorsal seta on the 2nd segment. The 5th and 6th segments bear 6 filaments unequal in length, one is about twice as long as the other 5. These filaments are not distally widened and are pointed at the tip. Dorsal margin of the limb is approximately equal in length to 5 short filaments. Height of antenna (on the 2nd segment) is about $20 \%$ of the length. Hairs are placed on the $2 \mathrm{nd}$, 3rd and 4th segments.

Second antenna. The exopodite is relatively thick and shorter than the protopodite. The total length of the 2nd-9th segments of the exopodite is approximately $40-50 \%$ of the 1 st segment in length. Basal segment of the endopodite is with long bristles " $a$ " and " $b$ " and hairs near its base, and without warty surface. The 2 nd segment is armed with hairs and without bristles " $c$ "-"e". The 5 filaments are very short, distally tapering, pointed at the tip and about 1/4-1/3 the length of the exopodite and protopodite. 
Table 2. Vertical distribution of species, genera and subgenera of Archiconchoecinae.

\begin{tabular}{|c|c|c|c|c|c|c|c|c|c|c|c|c|}
\hline \multirow{2}{*}{ Taxon } & \multicolumn{12}{|c|}{ Depth in $\mathrm{km}$} \\
\hline & $0-0.5$ & $0.5-1$ & $1-2$ & $2-3$ & $3-4$ & $4-5$ & $5-6$ & $6-7$ & $7-8$ & $8-9$ & $9-10$ & \\
\hline A.(A.) propinqua & + & & & & & & & & & & & \\
\hline A. (A.) instriata & + & & & & & & & & & & & \\
\hline A. (A.) aff. striata 1 & + & & & & & & & & & & & \\
\hline A. (A.) aff. striata 2 & + & & & & & & & & & & & 1) \\
\hline A. cuneata & + & + & & & & & & & & & & \\
\hline A. (A.) striata & + & + & & $?$ & & & & & & & & 2) \\
\hline A. fabiformis & + & + & + & 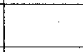 & & & & & & & & 3) \\
\hline A. poulseni & + & + & + & & & & & & & & & \\
\hline A. aff. cuneata 1 & + & & & & & & & & & & & \\
\hline A. cucullata & + & + & + & + & + & & & & & & & \\
\hline A. ecuneata & + & + & + & & & & & & & & & \\
\hline A. aff. cucullata 2 & & + & & & & & & & & & & \\
\hline A. aff. cuneata 2 & & + & & & & & & & & & & \\
\hline A. bispicula & & + & + & & & & & & & & & \\
\hline A. pilosa & & + & + & & & & & & & & & \\
\hline A. ventricosa & $?$ & + & + & $?$ & $?$ & & & & & & & 4) \\
\hline A. gastrodes & & + & + & + & & & & & & & & \\
\hline A. versicula & & & + & + & & & & & & & & \\
\hline A. falcata & & & + & & & & & & & & & \\
\hline A. bimucronata & & & + & & & & & & & & & \\
\hline A. arctica & & & + & + & + & & & & & & & 5) \\
\hline A. bidens & & & + & & & & & & & & & \\
\hline A. longiseta & & & + & & & & & & & & & \\
\hline A. simula & & & + & + & + & & & & & & & \\
\hline A. sp. nov. 1 & & & + & + & & & & & & & & \\
\hline A. orientalis & & & & + & & & & & & & & \\
\hline A. sp. nov. 2 & & & & + & & & & & & & & \\
\hline A. (A.) apertesulcata & & & & + & + & & & & & & & \\
\hline A. pljusnini & & & & & + & + & & & & & & \\
\hline A. inventricosa & & & & & + & + & + & & & & & \\
\hline A. bifurcata & & & & & + & & & & & & & \\
\hline A. aff. cucullata 1 & & & & & + & & . & & & & & \\
\hline A. aff. pljusnini & & & & & & + & & & & & & \\
\hline A. maculata & & & & & & & & & + & + & + & 6) \\
\hline Total & 11 & 12 & 16 & 9-?11 & 8-?9 & 3 & 1 & & 1 & 1 & 1 & \\
\hline
\end{tabular}

1) correct locality is unknown

2) also 1 juv: from $2700-2400 \mathrm{~m}$

3) only in a tow from $1200 \mathrm{~m}$ to surface

4) also in a tows from $3500 \mathrm{~m}$ to surface

5) only 1 male from $3800-935 \mathrm{~m}$

6) only 1 sample from $9500-7280 \mathrm{~m}$ 
Mandible. The epipodite is without bristles. The exopodite is represented by one short seta. The 1 st segment of the endopodite has straight dorsal margin and with one dorsal and 4 ventral setae, the 2nd segment with 3 dorsal and 2 ventral setae. The 3 rd segment bears 7 setae, of which largest seta is claw-like and about as long as the endopodite (on the dorsal side), and 2 first dorsal setae are slight (the 1st barely shorter than the 2nd seta). Basale is armed with 2 anterior and 2 lateral setae, and one anterolateral seta near the articulation. Basale endite has toothrow with 6 slightly separated serrated teeth and 2 short proximal bristles.

Maxilla. The basal segment bears 6 anterior and 4-5 posterior setae. The distal segment is armed with 2 claw-setae (posterior claw-seta long and anterior - very short) and 3 usual setae.

Fifth limb. The epipodite has 3 groups of $4+5+4$ plumose setae. The 1 st segment of the exopodite bears 5 ventral and 2 dorsal and the 2 nd segment is with only 2 ventral setae. The middle claw-seta of the 3 rd segment is about $60-70 \%$ of the exopodite in length and approximately as long as (slightly shorter) the dorsal claw-seta.

Sixth limb. The epipodial appendage is armed with 3 clusters of $5+5+6$ plumose setae. Two long plumose setae are placed on the endopodite. The 1 st segment of the exopodite has 2 dorsal and 4 ventral, the 2nd segment is with only one ventral and the 3rd segment with one dorsal and one ventral setae. The 4 th segment bears 2 long and slim dorsal and middle claw-setae and one short usual posterior seta; this middle claw-seta is about $80 \%$ and distodorsal seta of the 1st segment is $40-50 \%$ the length of the exopodite (on the dorsal side). Height of the exopodite is $60-65 \%$ of the length.

Caudal furca. This limb has 8 pairs of claws and single unpaired bristle.

\section{Comparison}

New genus sharply differs from the all other genera in having a clear lens-like structure near posteroventral corner of the each valve; longest seta on the 1st antenna is approximately twice as long as the other its setae; very short filaments are borne on the 2 nd antenna; longer posterior and shorter anterior setae are placed on the 3rd segment of the exopodite of the 6th limb.

This genus is close to Archiconchoecetta gen. nov., but separated (in addition to the above characters) mainly by the shape of shell, location of the right asymmetrical gland; shorter seta on the exopodite, and slightly separated teeth on the basal endite of the mandible; longest dorsal (no middle) seta is borne on the distal segment of the 5 th limb.

\section{Distribution}

Known only in the Sargasso Sea from 1500-2000 m.

\section{Distribution of ostracods of subfamily Archiconchoecinae}

The members of the subfamily Archiconchoecinae occur worldwide from the North to the South Pole and from the surface to maximal depth. They are common for the tropical and subtropical zones of the World Ocean (Deevey, 1987c; Deevey, Brooks, 1980), and less frequent in the temperate waters of the Northern Hemisphere (Chavtur, 1977a; 1977b; 1992) and in the South Ocean (Deevey, 1978a; 1982; 1983), and as exception in the Arctic Ocean (Chavtur, 1992) (Fig. 35). In waters of the Arctic Ocean only one specimen of ostracods of this group was recorder (Chavtur, 1978; 1992). The Archiconchoecinae ostracods prefer the deepwater zone of the World Ocean; only several of the subgenus Archiconchoecia (Archiconchoecia) are typical inhabitants of the epipelagical zone. Here belong only $A$. (A.) instriata nov. sp., A. (A.) propinqua nov. sp. and probably $A$. (A.) aff. striata 1 . To interzonal species (term by Vinogradov, 1968) belong $A$. (A.) striata and perhaps Archiconchoecetta fabiformis (the latter is known only in a vertical tow from $1200-0 \mathrm{~m}$ : Deevey, 1978c). As to the rest species they are typical representatives of the deepwater fauna, while Archiconchoecilla maculata occurs only in the hadal zone (deeper than $6000 \mathrm{~m}$ ).

With increasing depth the number of species rises (Table 2) to form the maximum in the layer 
1000-2000 $\mathrm{m}$. However it should be expected that this maximum boundary will shift somewhat lower with time, since in the tropical-subtropical zone layer-by-layer catches were done only down to 2000 $\mathrm{m}$ depth, and total catches (from around $3000-4000 \mathrm{~m}$ ) did not provide realistic information on vertical distribution of ostracods. Most genera were recoded between $3000-4000 \mathrm{~m}$.

The species of Archiconchoecinae do not form mass accumulation. In catches they are usually represented by single specimens. The greatest abundance of 500 specimens $/ 1000 \mathrm{~m}^{3}$ was found for $A$. (A.) striata from the Sargasso Sea in 1970 (Deevey, 1978c).

Ostracods of this subfamily are filter-feeding organisms and belong (depending on depth) either to herbivores or detrivores. The universal structure of the mandible as well as tiny sizes of these organisms enable them to command the greatest depth and lead in abundance among ostracods of other subfamilies in the hadal zone (Chavtur, 1977a; 1977b; 1992).

The number species of this group in the World Ocean is not high as compared to other pelagic ostracod groups. One should expect descriptions of new species mainly from tropical and subtropical regions. In the number of species only of the subfamilies Halocypridinae and temporarily Euconchoecinae, rank second to this group. The composition of the latter subfamily is very diverse at great deeps (according to unpublished author's data).

Widely-distributed (literature data) species Archiconchoecia striata is actually a set of morphologically close species: Archiconchoecia (Archiconchoecia) striata, A. (A.) instriata nov. sp., A. (A.) propinqua nov. sp., A. (A.) aff. striata 1, A.(A.) aff. striata 2 and Archiconchoecia (Archiconchoecidia) apertesulcata nov. sp. With time, possibly this list will be augmented.

\section{Acknowledgments}

I wish to thank Dr. M. E. Vinogradov and Dr. J. A. Rudjakov of Institute of Oceanology, Russian Academy of Science, for the plankton materials upon which partially study is based and for the environmental data presented in the station data herein. Also I am greatly indebted to Dr. E. I. Shornikov of Institute of Marine Biology, Far East Branch, Russian Academy of Science, for his advice during the course of this study. This work was supported by the grant from the Russian Fundamental Fund of Investigation (RFFI).

\section{References}

Alcaraz M., 1977. Cladoceros y ostracodas de los alrededores del Estrecho de Gibraltar en junio-julio de 1972. Resultados Expediciones cientificas del Bugue Oceanografico Cornide de Saavedra, 6, 41-63.

Alcaraz M., Manrigues M., and Vazgues A., 1975. Ostracodos pelagicos del SW de Portugal: Estructura de las comunidades. Investigaciones Pesgueras, 39 (2), 379-396.

Angel M. V. 1969a. Planktonic ostracods the Canary Island region; their depth distributions, journal migrations, and community organization. Journal of the Marine Biological Association of the United Kingdom, 49, 515553.

Angel M. V. 1969b. Repeated samples from a deep midwater planktonic ostracod community. Journal of Experimental Marine Biology and Ecology, 3, 76-89.

Angel M. V. 1977. Studies on Atlantic halocyprid ostracods: vertical distribution of the species in the $1000 \mathrm{~m}$ in the vicinity of $44^{\circ} \mathrm{N}, 13^{\circ} \mathrm{W}$. Journal of the Marine Biolgical Association of the United Kingdom, 57, 239252.

Angel M. V., 1979. Studies on Atlantic halocyprid ostracods: their vertical destributions and community in the central gyre region along latitude $30^{\circ} \mathrm{N}$ from off Africa to Bermuda. Progress of Oceanography, 8, 3-124.

Angel M. V., 1981. Ostracoda. Atlas de zooplancton del Atlantico sudoecidental y metodos de trabajo con el zooplancton marino. Publication especial del INIDEP Mar del Plata, Argentina, 543-585.

Angel M. V., 1983. A vertical profile of planctonic ostracods from depth of 1500-3900 m at northeast Atlantic Station. In, Maddocks R. E. (ed.). Applications of Ostracoda: Proceedings of the Eighth International Symposium on Ostracoda (July 26-29, 1982). Departament of geosciences, University of Houston, Houston, 549-559. 
Angel M. V., 1984. The diel migrations and distributions within a mesopelagic community in the North East Atlantic. 3. Planktonic ostracods, a stable component in the community. Progress of Oceanography, 13, 319351.

Angel M. V. 1993. Marine planktonic ostracods. Synopsis of the British Fauna (new Series), No 48. Published for the Linnean Society of London and the Estuarine and Coastal Sciences Association by Field Studies Council. Shrewsbury. 240p.

Angel M. V., and Fashan M. J. R., 1975. Analyses of the vertical and geographic distribution of the abundant species of planktonic ostracods in the North-East Atlantic. Journal of the Marine Biology Association of the United Kingdom, 55, 709-737.

Angel M. V., Hargreaves P., Kirkpatrick P. and Domanski P., 1982. Low variability in planktonic and micronectonic populations at $1000 \mathrm{~m}$ depth in the vicinity of $42^{\circ} \mathrm{N}, 17^{\circ} \mathrm{W}$; evidence diel migratory behavior in the majority of species. Biological Oceanography, 1, 287-319.

Benassi G., Ferrari I., Rossi V., Sei S., Angel M.V., and McKenzie K. G., 1998. Distribution and taxonomy of planktonic ostracods of the Eolian Islands (Mediterranean Sea), 3 Congr. Europ. Des Ostracodologistes. Paris-Bierville 8-12 July 1996, Bull. Centre Rech. Elf Explor. Prod., 3, 3-25.

Brady G. S., 1902. On new imperfectly-known Ostracoda, chiefly from a collection in the Zoological Museum, Copenhagen. Transaction of the Zoological Society of London, 16, 4 (1), 179-210.

Brady G. S., 1903. Report on dredginds and other marine research off the north-east of England in 1901. Transaction of National Historical Society of London, 14 (5), 87-101.

Chavtur V. G., 1977a. [Species composition and vertical distributions of pelagic ostracods in the region of Kurile Kamchatka Trench.]. Trudy Instituta okeanologii AN SSSR, 108, 136-164 [In Russian].

Chavtur V. G., 1977b. [Fauna of pelagic ostracods of the Halocyprididae family in the northwestern part of the Pacific ocean.]. Biologija morja , 1, 28-38 [In Russian].

Chavtur V. G., 1977c. Fauna of pelagic ostracods of the Halocypridinae family in the northwestern part of the Pacific ocean. Sovetskye Trudy Marine Biology, 3 (3), 18-26.

Chavtur V. G., 1978. [Species composition and feature of distribution of plankton ostracods (Ostracoda, Myodocopa) in the central part of Arctic Basin] Zoologickesky zurnal, 57 (12), 1790-1798 [In Russian].

Chavtur V. G. 1987. Three new species of pelagic ostracods from the North Pacific. Zoologichesky zhurnal, 66 (6), 943-949 [In Russian].

Chavtur V. G., 1991. [History - bibliograpfic review and analysis of study recent ostracod-myodocops of the oceans world.]. Vladivostok Dalnevostochnoe Otdelenie Akademii Nauk SSSR, 2 (3), 136 pp. [In Russian].

Chavtur V. G., 1992.[Composition, structure and distribution benthic and pelagic ostracods of the superorder Myodocopa of temporate and cold waters of the Northern Hemisphere.]. Institut Biologii morija Dalnevostochnoe Otdelenie Rossyjskoj Akademii Nauk. Vladivostok, 155 pp. 30 figs., bibl. 96 nam. Deponent VINITI, N 3016-V92, 20.10.92. [In Russian].

Chen Q., Yin J., and Zhang G., 1983. Studies on pelagic ostracods in the central and northern parts of the South Chine Sea. Contribsutions on Marine Biological Research. of the South China Sea, 3 (1), 82-132 [in Chinese].

Chen R., Lin J., 1994a. The distribution of planktonic Ostracoda between the source of Kuroshio and west of Taiwan Strait. Acta Oceanologica Sinica, 13 (3), 445-452.

Chen R., and Lin J., 1994b. Ecological study on Ostracoda in the central South Chine Sea. Acta Oceanologica Sinica, 13 (3), 413-423.

Chen R., and Lin J., 1995. Pelagic ostracoda in China seas China. Ocean, 134 pp. [in Chinese].

Cleve P. T., 1905. The plankton of the South African Seas. III. Halocyprididae, Marinae investigations in the South Africa. Cape Town, 4, 129-132.

Deevey G. B., 1968. Pelagic ostracods of the Sargasso Sea off Bermuda. Peabody Museum of Natural History Yale University. Bull., 26, $125 \mathrm{pp}$.

Deevey G. B., 1970. Pelagic ostracods (Myodocopa, Halocyprididae) from the North Atlantic off Barbados. Proceedings of the Biolical Society of Washington, 82 (62), 799-824.

Deevey G. B., 1971. The annual cycle in quantity and composition of the zooplankton of the Sargasso Sea off Bermuda. I. The upper $500 \mathrm{~m}$. Limnology and Oceanogr, $16(2), 219-240$.

Deevey G. B., 1974. Pelagic ostracods collected on Hudson 70 between the equator and $55^{\circ} \mathrm{S}$ in the Atlantic. Proceedings of the Biological Society Washington, 87 (32), 351-380. 
Deevey G. B., 1978a. A taxonomic and distributional study of the planktonic ostracods collected on three cruises of the "Eltanin" in the South Pacific and the Antarctic Region of the South Pacific. Biology of the Antarctic Seas, VIII Antarctic Research, 28 (3), 43-70. (American Geophysical Union).

Deevey G. B., 1978b. The planktonic ostracods of the Cariaco Trench and adjacent waters. Proceeding of Biolical Society of Wachington, 91 (1), 52-73.

Deevey G. B., 1978c. On new and little known species of Archiconchoecia (Myodocopa, Halocyprididae) from the Sargasso and Caribbean Seas, with descripthion of seven new species. Bulletin of Florida State Museum, Biological Science, 23 (2), 105-138.

Deevey G. B., 1982. Planktonic ostracods of the north Atlantic off Barbados. Bulletin of Marine Science, 32 (2), 467-488.

Deevey G. B., 1983. Planktonic ostracods (Myodocopa, Halocyprididae) from six Eltanin cruises in South Pacific and Antarctic waters. Journal Crustacean Biology, 3 (3), 409-412.

Deevey G. B., and Brooks A. L., 1980. The planktonic ostracods of the Sargasso Sea off Bermuda: species composition and vertical and seasonal distribution between the surface and $2000 \mathrm{~m}$. Bulletin of Florida State Museum, Biological Science, 26 (2), 37-124.

Drapun I. E., 1981. [Pelagic ostracods from the subtropical region of the South Atlantic]. Vestnik zoologii, 3, 7476. [In Russian].

Drapun I. E., 1983. [Pelagic ostracods from the south-west sector of the Southatlantic subtropical circulation]. Ecologia morja, 14, 33-37. [In Russian].

Drapun I. E., 1988. [Correlation line size with biomass of planktonic ostracods]. Ecologija morja, 28, 46-51 [In Russian].

Ellis C. J., 1985. The effects of proximity to the continental slope sea-bed on pelagic halocyprid ostracods at $49^{\circ} \mathrm{N}-$ $13^{\circ} \mathrm{W}$. Journal of the Marine Biological Association of the Uited Kindom, 65, 923-949.

Fasham M. J. R., Angel M. V., and Roe H. S. J., 1974. An investigation of the spatial pattern of zooplankton using the Longhurst-Hardy planktonic recorder. Journal of Experimental Marine Biology and Ecology, 16: 93-112.

Fowler G. H., 1909. Biscayan plankton collected during a cruise of H. M. S. "Research", 1900. Pt. XII. The Ostracoda. Transaction of the Linneus Society of London, Zoological Series 2, 10, 219-358.

Granata L., and Caporiacco L., 1949. Ostracodes marins recuillis pendant les croisieres du Prince Albert l-er de Monaco. Resultats Campagnes Scientifiques, Prince Albert I, 109, 1-51.

Gamulin T., 1948. Contribution a' la connaissance du zooplancton de la zone insulaire de la Dalmatie. moyenne. Acta Adriatica, 3 (7), 3-38. (citation on: Gooday A. J., Angel M. V., 1977).

George J., 1979. Redescription of Archiconchoecia striata Muller (Ostracoda, Halocyprididae) and its distridution in the Northern Indian Ocean. Crustaceana, 36 (2), 123-128.

George J., and Nair V. P., 1980. Planktonic ostracods of the Northern Indian Ocean. Mahasagar - Bulletin of the National Institute Oceanography, 13 (1), 29-44.

Gonzales L.C., and Breman E., 1982. Distribution of planktonic ostracoda in the surface warters of the Bonaire Basin and adjacent seas. Crustaceana, 42 (2), 201-211.

Gooday A. J., and Angel M. V., 1977. Distribution of planktonic Ostracoda (Halocyprididae) in the North Adriatic with the description of a new subspecies, Conchoecia porrecta adriatica. Crustaceana, 32 (2), 139-154.

Grice G. D., and Hart A., 1962. The abundance seasonal occurrence and distribution of the epizooplankton between New York and Bermuda. Ecological Monographs, 32 (4), 287-309.

Hanai T., Ikeya N., and Yajima M., 1980. Checklist Ostracoda from Southeast Asia. Bullitin of the University Museum, University of Tokyo, 17, $236 \mathrm{pp}$.

Hillman N. S., 1969. Distribution of selected groups of marine invertebrates in waters south of $35^{\circ} \mathrm{S}$ latitude. Antarctic Map Folio Series, 11, Halocyprididae, 29-30.

Hure J., 1961. Distribution saisonniere et migration journaliere verticale du zooplancton dans la region profonde de I' Adriatique. Acta Adriatica, 9 (6), 3-59.

Juday C., 1906. Ostracoda of the San Diego Region. I. Halocyprididae. University of California Pablications in Zoology, 3 (2), 13-38.

Leveau M., 1965. Contribution a l' etude des ostracodes et cladoceres du Golfe de Marseille. Recuel des travaux de la Station marine Endoume, Marseille, Fascicule hops serie supplement, 37 (53), 161-246.

Leveau M., 1967. Ostracodes pelagiques du sud-ouest de I' ocean Indien (region de Tulear). Recueil des travaux de la Station marine Endoume, Marseille, Fascicule hors serie supplement, 6, 63-70. 
Leveau M., 1969. Ostracodes pelagiques recuillis lors de la $3^{\circ}$ campagné de I' aviso “Commandant Robert Giraund". Recuel des travaux de la Station marine Endoume, Marseille, 8, 123-142.

Martens J. M., 1979. Die pelagischen Ostracoden der Expedition Marchile I (Sudost-Pazifik), II: Systematik und Vorkommen (Crustacea: Ostracoda: Myodocopa). Mitteilungen aus dem Hamburgischen zoologischen Museum und Institut, 76, 303-366.

Martens J. M., 1981. Die pelagischen Ostracoden der Marchile 1-Expedition (Sudost-Pazifik), I: Verbreitung, zoogeographie und bedentung als indikatoren fur wasserkorper (Crust. Ostracoda: Myodocopida). Studies on Neotropical Fauna and Environment, 16, 57-97.

McKenzie K. G., Ducasse O., Dufour E., and Peypouquet J. P., 1979. Monographie bibliographique, statigraphique et paleocologique sur les ostracodes cenozoiques du Bussin d' Aquitain et du Golfe de Gascogne. Bulletin de Institut Geology, Bassin Aquitaine Talence, 195 pp.

Moraitou-Apostolopoulou M., 1981. Planctonic ostracods collected between 1964 and 1973 from different Greek Sea areas. Vie et Milieu, 31 (2), 171-176.

Müller G. W., 1894. Die ostracoden des Golfes von Neapelund der angbenzenden meeresabschnitte. Fauna und flora des Golfes von Neapel. Naples. Zool. Stat. Berlin, 21, 404 pp.

Müller G. W., 1906. Ostracoda. Wissenschaftlike. Ergebnisse Deutsche Tiefsee-Expedition auf dem Dampfer "Valdivia", 8, 1-154 pp.

Müller G. W., 1908. Die Ostracoden. Der Deutschen Sudpolar-Expedition 1901-1903. Sudpolar-Expedition 19011903, Zoologie, Berlin, 10 (2), 53-184.

Müller G. W., 1912. Ostracoden. Das Tirreich, Berlin, 31, 434 pp.

Poulsen E. M., 1969. Ostracoda -Myodocopa. Pt III A. Halocypriformes - Thaumatocyprididae and Halocypridae. Dana - Reptort, 75, $100 \mathrm{pp}$.

Poulsen E. M., 1973. Ostracoda -Myodocopa. Pt III A. Halocypriformes - Halocypridae, Conchoecinae. DanaReptort, 84, 224 pp.

Puri H. S., 1963. Preliminary notes on the Ostracoda of the Gulf of Naples. Experientia, 19 (368), 1-16.

Schweiger L., 1912. Adriatische cladoceren und plankton ostracoden. Sutzungeber.-Berlin, Akademia Wissenschaftlicke, Wien, 121 (5), 239-175. (citation on: Gooday A. J., Angel M. V., 1977).

Skogsberg T., 1931. Ostracods. In, Murray J., Hjort J. (eds.) Report of the scientific results of the "Michael Sars" North Atlantic Deep-Sea Expedition 1910, 5, 1-26.

Tseng W. Y.,1970. Occurence of ostracods in the neighbouring seas of Taiwan. In, Sugawara K. (ed.). The Kuroshio: Proceedings of the 2nd CSK Symposium, Tokio, 237-295.

Vinogradov E. M. 1968. Vertical distribution of the oceanic zooplankton. Publishing House "Nauka", Moscow, 320 pp. [In Russian].

Vucetic T., 1977. Les principales masses d' eau en Adriatique et leur inatuence sur les communautes pelagiques Journees Etudude Planctonology, Monaco, C.I.E.S.M., 105-114. (citation. on: Gooday A. J., Angel M. V., 1977). 